\title{
DINÂMICA EVOLUTIVA E VARIABILIDADE DE POPULAÇÕES DE MELANCIA Citrullus lanatus (Thunb.) Matsum \& Nakai. EM TRÊS REGIÕES DO NORDESTE BRASILEIRO
}

\author{
ROBERTO LISBÔA ROMÃO \\ Engenheiro Agrônomo
}

Orientador: Prof. Dr. PAULO SÓDERO MARTINS

Dissertação apresentada a Escola Superior de Agricultura " Luiz de Queiroz ", da Universidade de São Paulo, para obtenção do titulo de mestre em Agronomia. Área de concentração: Genética e Melhoramento de plantas.

PIRACICABA

Estado de São Paulo - Brasil

Outubro, 1995 
Dados Internacionais de Catalogaçāo na Publicação (CIP)

DIVISĀO DE BIBLIOTECA E DOCUMENTAÇĀO - Campus "Luiz de Queiroz"/USP

Romão, Roberto Lisbôa

Dinâmica evolutiva e variabilidade de populaçōes de melancia

Citrullus lanatus (Thunb.) Matsum \& Nakai. em três regiōes do nor

deste brasileiro / Roberto Lisbôa Romão. - - Piracicaba, 1995.

75p. : il.

Dissertação (mestrado) - Escola Superior de Agricultura Luiz de Queiroz, 1995.

Bibliografia.

1. Melancia - Germoplasma - Brasil (nordeste) 2. Melancia - Popu lação - Variedade I. Título 


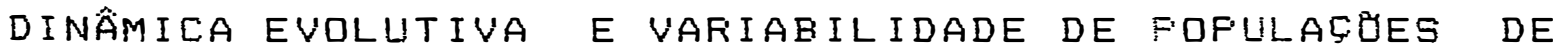 MELANCIA Citrulius ianatus (Thunb.) Matsum} EM TFEES REGIÖES DO NOFIDESTE BFiAs ILEIFIO

ROBERTO LISBÔA POMÃO
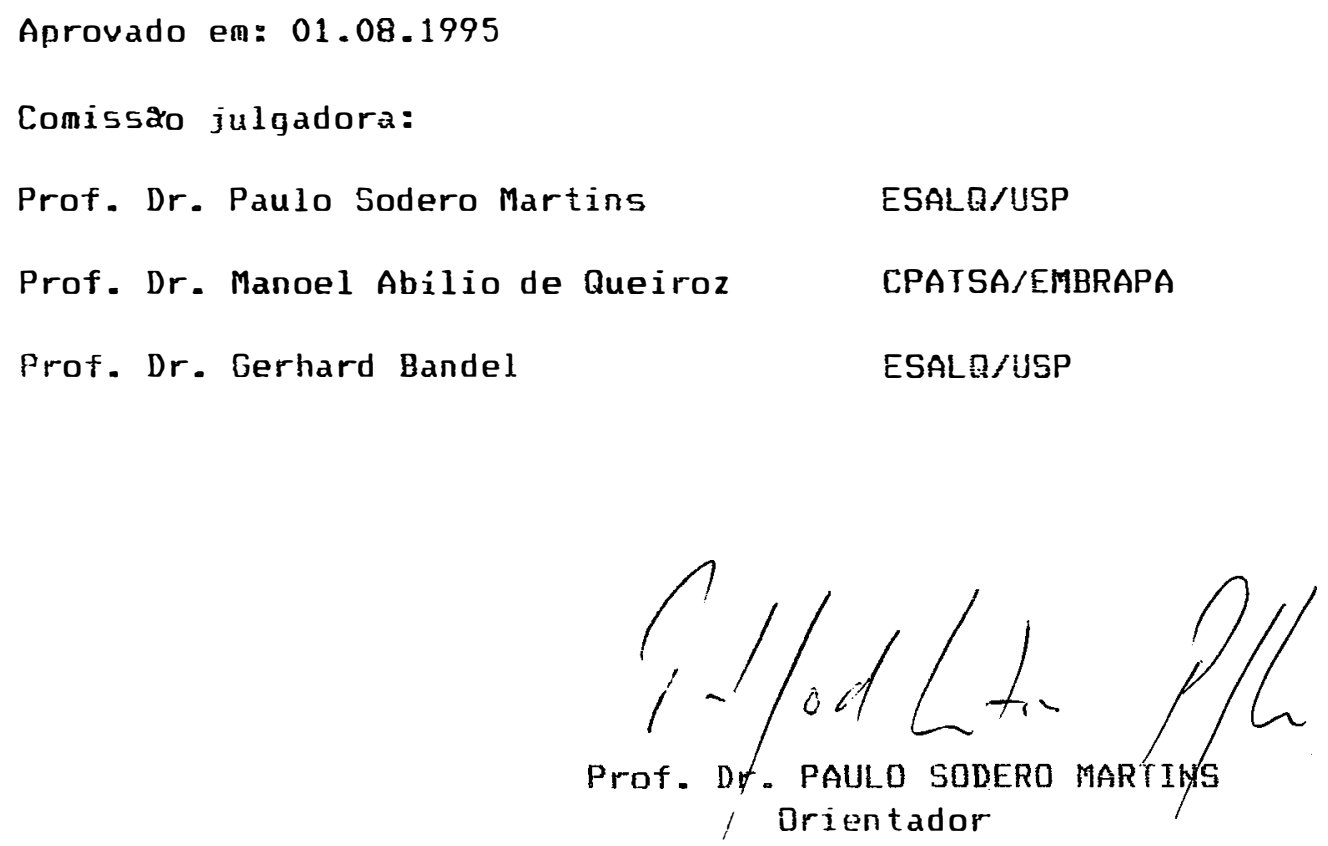
Aos meus FAMILIARES pelo apoio e encorajamento sempre.

OFEREÇO

A Manoel Abílio de Queiroz e Pierre Verger - onde a curiosidade e o respeito pelo saber empírico, e o rigor do saber cientifico, se harmonizam na leitura e compreensão da diversidade...

E a Maria Amélia Matos, Maria Grace Chaves Costa e Terezinha Lisbôa Romão - três mulheres que a seus modos, nas suas diversidades me ensinaram muito.

DEDICO

"O pensamento parece uma coisa à-toa mas como é que a gente voa quando começa a pensar " Lupicínio Rodrigues 


\section{AGRADECIMENTOS}

Aos Professores Paulo Sodero Martins e Manoel Abílio de Queiroz, pela orientação, disponibilidade, amizade, humanidade e exemplo do fazer ciência.

Aos Pesquisadores, técnicos e funcionários do Centro de Pesquisa Agropecuária do Trópico Semi-Árido (CPATSA/EMBRAPA), pelo auxílio durante a condução e análise dos experimentos.

Ao Conselho Nacional de Pesquisa e Desenvolvimento (CNPQ) e a Fundação de Apoio à Ciência e Tecnologia de Pernambuco (FACEPE), pela oportunidade e auxílio financeiro concedido.

Ao Prof. Roland Vencovsky e à pesquisadora Célia Torres (CENARGEN/EMBRAPA), pela disponibilidade e sugestões nas análises estatísticas.

Ao Departamento de Genética da ESALQ/USP pela oportunidade de aprimoramento.

A E. Adelaide Coelho de Queiroz, pelo incentivo e generosidade.

Aos amigos Patrick e Aignes Caron, Luciano Nass e Nilce Puga pela amizade, apoio e paciência.

Aos grandes amigos e colegas Alexandre Oliveira de Souza, Floridalma Morales, José Geraldo de A. Assis, Marco Antônio de Souza, Maria Inês F. Faraldo, Semíramis R. R. Ramos, pelos momentos de discussão e descontração durante o curso.

Aos docentes do Departamento de Genética, pelos ensinamentos e aos funcionários, pela colaboração e atenção dispensada.

Aos colegas do curso de Pós-graduação, pela convivência, apoio e incentivo durante o curso.

Aos companheiros da área de Genética Ecológica, além dos ensinamentos e discussões, pela cumplicidade e amizade.

Aos professores e colegas que nos acudiram nas análises estatísticas. 


\section{SUMÁRIO}

RESUMO vi

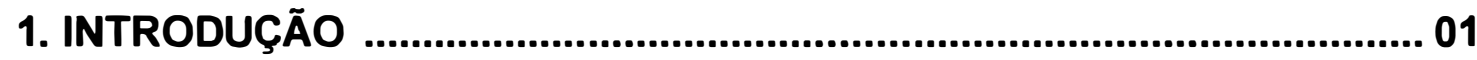

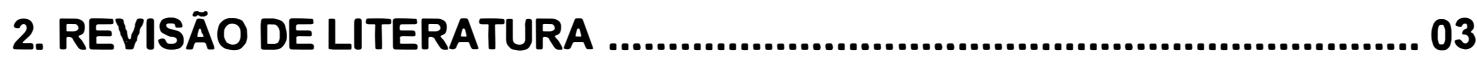

2.1. Aspectos gerais da melancia ....................................................... 03

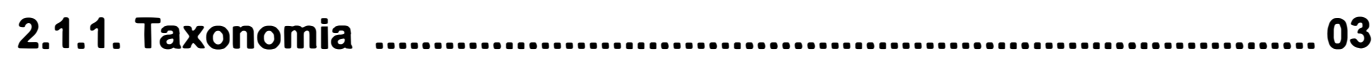

2.1.2. Aspectos botânicos ............................................................... 03

2.1.3. Origem e distribuição geográfica ................................................ 04

2.2. A melancia no Brasil ......................................................................... 05

2.2.1. Tráfico de escravos e a introdução da melancia.......................05

2.2.2. Introdução no Nordeste e em outras regiões .........................07

2.3. Fluxo gênico e biologia de populações de Cucurbitáceas ............. 12

2.4. Uso do germoplasma e medidas de variabilidade ......................... 14

2.4.1. Recursos genéticos e caracterização da variabilidade..........14

2.4.2. Estudo da variabilidade em germoplasma de Cucurbitáceas 16

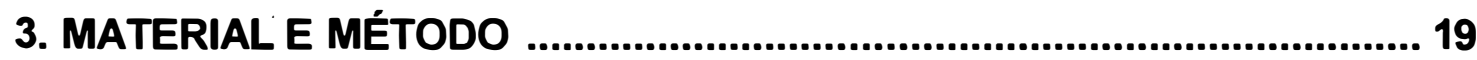

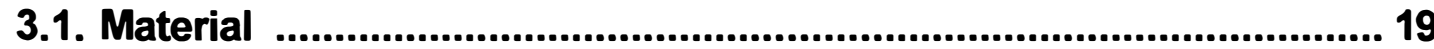

3.1.1. Regiões estudadas ...............................................................19

3.1.2. Germoplama utilizado ...........................................................19

3.1.3. Local do experimento ..................................................................20

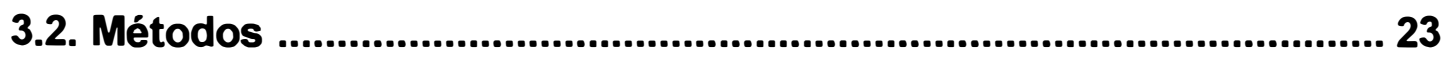

3.2.1. Caracterização morfológica, fisiológica e fenológica .......... 23

3.2.2. Observações ecogeográficas e de sistema de cultivo ............26

3.2.3. Metodologias estatísticas .................................................... 26

3.2.3.1. Cracteres qualitativos ...................................................26 
3.2.3.2. Caracteres quantitativos- análises univariadas ............. 26

3.2.3.3. Caracteres quantitativos- análise multivariada ................29

4. RESULTADOS E DISCUSSĀO ............................................................ 31

4.1. Variação qualitativa e quantitativa em 39 populações de melancia 31

4.1.1. Variação para caracteres qualitativos ................................... 31

4.1.2. Variação entre populações dentro de cada região ................ 36

4.1.3. Variação entre regiōes ........................................................ 38

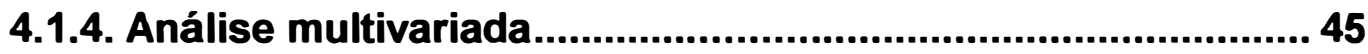

4.2. A Dinâmica evolutiva da melancia no Nordeste do Brasil ............ 50

4.3. Considerações finais sobre a variabilidade em melancia............. 61

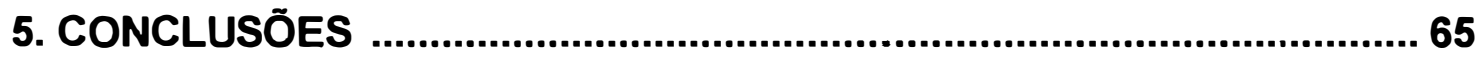

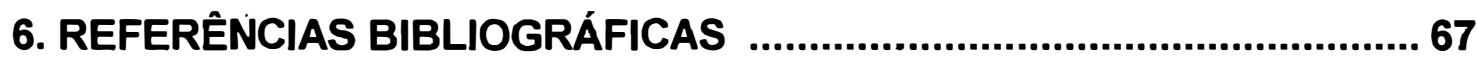




\title{
DINÂMICA EVOLUTIVA E VARIABILIDADE DE POPULAÇÕES DE MELANCIA Citrullus lanatus (Thunb.) Matsum \& Nakai. EM TRÊS REGIÕES DO NORDESTE BRASILEIRO.
}

\author{
Autor:ROBERTO LISBÔA ROMÃO \\ Orientador: Prof. Dr. PAULO SÓDERO MARTINS
}

\section{RESUMO}

Este trabalho teve como objetivos: a) avaliar a variabilidade fenotípica existente dentro e entre trinta e nove populações de melancia (Citrullus lanatus) coletadas em três regiões do Nordeste brasileiro e, b) estabelecer o modelo da dinâmica evolutiva dessa cultura, para as condições de cultivo tradicional, nesta região do Brasil.

Foram avaliadas morfometricamente, trinta e nove populações, 13 populações por região , coletadas no Médio Sertão Maranhanse, na Depressão Sertaneja e na região Central da Bahia.

As análises univariadas e multivariadas revelaram que há uma grande variabilidade para a quase totalidade das variáveis estudadas, e que a mesma está distribuida tanto dentro quanto entre as regiões. O critério de classificação por região, diferencia os materiais e esta de acordo com a variação morfométrica encontrada entre as populações e os dados históricos levantados.

Propõe-se um modêlo da dinâmica evolutiva de Citrullus lanatus, onde componentes históricos ( o tráfico de escravos e a colonização do Nordeste), genéticos ( a dormência de sementes e explosão dos frutos) e ecológicos (dispersão das 
sementes pelo lobo guará e sementes deixadas no campo após consumidos os frutos pelo agricultor na própia roça) são identificados como responsäveis pela manutenção e amplificação da variabilidade para as condições de cultivo tradicional no Nordeste brasileiro.

Conclue-se que o Nordeste brasileiro, é um centro de diversidade para a melancia e, consequentemente, uma área importante para a coleta de germoplasma. 


\title{
EVOLUTIONARY DYNAMICS AND VARIABILITY OF WATERMELON POPULATIONS, Citrullus lanatus (Thumb.) Matsun \& Nakai, IN THREE REGIONS OF THE BRAZILIAN NORTHEAST.
}

\author{
Author : Roberto Lisbôa Romão \\ Adviser : Paulo Sodero Martins
} SUMMARY

This work had the following objectives: a) to evaluate the phenotypic variability within and among thirty nine watermelon populations (Citrullus lanutus), collected in three geographic regions of the Brazilian Northeast and, b) to establish an evolutionary dynamic model for this crop, under the conditions of traditional agriculture in this geographic region of Brazil.

Thirty nine populations, thirteen from each region (Médio Sertão Maranhense, Depressão Sertaneja and the region Central Bahia), were evaluated morphometrically.

The univariate and multivariate analysis showed large variability for the majority of the variables analysed, and this variability was dispersed within and among regions. The criteria of classification by region, differentiated the materials and it is in accordance with the morphometric variability found among the populations, and with the historical records.

A model of evolionary dynamics of Citrullus lanatus cultivation was proposed, where the historical components (the slaves traffic and the colonization of the Northeast), genetics (seed dormancy and fruit explosion) and ecological effects (seed dispersal by the guara wolf and seeds left in the field, as result of the consumption by the farmers), were identfied as responsible by the maintenance and amplification of the variability in the traditional agriculture of the Brazilian Northeast. 
It was concluded that the Brasilian Northeast is a center of diversity of watermelon and, as a consequence, an important area for germplasm collection. 


\section{INTRODUÇÃO}

A produção de melancia no Brasil, em 1990, foi de 794.580 t. Na região Nordeste, a Bahia responde por $43 \%$ da produção nacional segundo SOBRINHO. ${ }^{1}$

Esta produção é resultado de dois sistemas agrícolas distintos. O primeiro deles, melhor coberto pelas estatísticas, se refere ao cultivo efetuado sob irrigação utilizando, de um modo geral, cultivares americanos e japoneses, de base genética estreita e bastante suscetiveis às doenças (QUEIROZ, 1993). O segundo sistema é realizado em pequenas propriedades, sendo dependente de chuva e utilizando variedades locais.

No cultivo irrigado destacam-se os Estados do Piauí, Pernambuco e - Bahia, sendo que nestes dois últimos se sobressaem os perímetros irrigados dos Pólos de Irrigação de Barreiras e de Petrolina/Juazeiro.

Para as áreas cultivadas dependentes de chuva, com variedades locais, não se tem estatísticas, e há diferentes realidades, desde agricultores que mantêm as plantas para consumo famíliar e de pequenos animais, até áreas com alto potencial produtivo, onde já se observa um sistema organizado de comercialização da produção. Destacam-se, nesta modalidade, os Estados do Piaui e Bahia e o Distrito de Massaroca-BA segundo Queiroz $z^{2}$.

A provável grande amplitude do germoplasma trazido de diferentes partes da África associada à forma de cultivo nas pequenas propriedades, sem a utilização dos chamados insumos modernos, estabelecendo um processo de seleção das sementes para o próximo plantio de acordo com o critério e necessidade de cada produtor, além da diversidade de situaçōes ecológicas, no tempo e no espaço, deve ter gerado a ampla variabilidade observada hoje nas áreas de cultivo tradicional. Por outro lado, junto às localidades que já apresentam uma boa produção e organização da comercialização, baseadas em variedades locais, observa-se um grande risco desubstituição destas pelas variedades comerciais devido ao mercado remunerar melhor as últimas.

\footnotetext{
${ }^{1}$ RAMALHO SOBRINHO. Congresso Brasileiro de Olericultura . Comunicação pessoal, 1994.

${ }^{2}$ QUEIROZ, M. A. de. (CENTRO DE PESQUISA AGROPECÚARIA DO TRÓPICO SEMI-ÁRIDO EMBRAPA) Comunicação pessoal, 1994.
} 
As pressões de mercado, somadas às secas freqüentes, às inundações por barragens, e ao êxodo rural, dentre outros fatores, vêm aumentando o risco de extinção das variedades locais. E estas, como já se demonstrou em diversos estudos, são detentoras de genes de resistência às principais doenças que atacam os cultivos da área irrigada como, virose, oídio e micosferela (ARAÚJO et al., 1987; ARAÚJO \& SOUZA, 1987; ARAÚJO \& SOUZA 1988; SOUZA et al., 1988; ARAÚJO et al., 1989; DIAS et al., 1989; QUEIROZ et al., 1994), além de constituirem material de interesse direto para o melhoramento (CLEVELAND et al., 1994).

Constatada a importância desta variabilidade e o risco iminente de perda, o CPATSA - CENTRO DE PESQUISA AGROPECUÁRIA DO TRÓPICO SEMIÁRIDO/EMBRAPA - (Petrolina-PE), iniciou um programa de coleta de germoplasma de cucurbitáceas no Nordeste do Brasil (QUEIROZ, 1993).

Embora vários trabalhos tenham discutido as formas e a necessidade - de viabilizar o uso dos bancos de germoplasma, as ações necessárias para estimular o seu uso e a importância da caracterização, avaliação e documentação com este fim (FRANKEL \& SOULE, 1981; WILLIAMS, 1984; PERRY et al., 1991; VILELA-MORALES \& MENDES, 1983), pouco tem sido realizado no que diz respeito às cucurbitáceas.

A utilização de germoplasma, quer seja este proveniente de introdução de materiais exóticos ou de variedades locais, está fortemente ligada ao conhecimento da base genética desses materiais, da quantidade de variabilidade existente e do modo como essa variabilidade está estruturada nas populações.

A quantificação da variabilidade morfológica e fisiológica e a compreensão dos processos evolutivos que estão atuando nas populações de melancia do Nordeste, devem auxiliar no entendimento da estrutura genética dessas populações e possibilitar um manejo e uso mais racional desses recursos genéticos .

Dentro desse contexto, o presente estudo teve como objetivos :

a) avaliar a variabilidade fenotípica existente entre trinta e nove populações de melancia e dentro das três regiões coletadas no Nordeste brasileiro e,

b) estabelecer o modelo de dinâmica evolutiva dessa cultura, para as condições de cultivo tradicional, nesta região do Brasil. 


\section{REVISÃO DE LITERATURA}

\subsection{Aspectos gerais da melancia}

\subsubsection{Taxonomia}

NAVOT \& ZAMIR (1987), com base em estudo filogenético do gênero Citrullus utilizando isoenzimas e proteina de semente, e no qual foram analisadas 499 populações de C.lanatus, C.lanatus var. citroides, C.colocynthis, C. ecirossus, Praecitrullus fistulosus, Acanticefalus naudinianus, concluíram que o gênero é composto por apenas três espécies: C. lanatus (Thunb.) Matsum \& Nakai, incluindo além da espécie cultivada, a $C$. lanatus var. citroides; C colocynthis (I.) Shrad, e a terceira C. ecirossus. As outras duas espécies que eram anteriormente classificadas neste gênero apresentaram distâncias genéticas em relação às espécies de Citrullus o que apoia a nova classificação.

De acordo com CARVALHO et al. (1988) a melancia é classificada do seguinte modo: Divisão: Magnoliophyta (=Spermatophita); Classe: Magnoliopsida (=Angiospermae); Subclasse: Dilleniidae (=Dicotiledoneae); Ordem: Violales (=Campanulales); Familia: Cucurbitaceae; Gênero: Citrullus; Espécie: Citrullus lanatus (Thunb.) Matsum \& Nakai.

Até 1963, prevalecia a denominação para melancia proposta por Lineu (Citrullus vulgaris), mas naquele ano, THIERET (1963) chama atenção para o nome correto que seria Citrullus lanatus (Thunb.) Mansf.

\subsubsection{Aspectos botânicos.}

A melancia é uma planta anual, rasteira, de haste sarmentosa possuindo folhas de tamanho médio, triangulares e lobuladas.

Todos os cultivares de melancia produzem flores estaminadas e pistiladas, exceto algumas poucas que são hermafroditas. As flores são solitárias nas axilas, sendo que, as pistiladas ou hermafroditas ocorrem a cada sete axilas, enquanto as estaminadas ocupam as axilas intermediárias. As pétalas das flores são unidas e possuem 5 lóbulos, com três estames ao redor de um curto e grosso estilete e um estigma trilobado. Todas as flores estaminadas e a maioria das pistiladas abrem-se, e não existe um ciclo 
definitivo para o pegamento de frutos. Este pegamento é mais ou menos irregular através das estações, ou pelo menos enquanto as plantas estão vigorosas (PINTO, 1977).

As flores abrem-se uma ou duas horas após o aparecimento do sol. As flores masculinas e femininas abrem-se no mesmo dia. As anteras têm deiscência quando a corola se expande, mas o pólen permanece nas anteras em massas. O estigma está receptivo o dia todo, embora a maioria das polinizações aconteça pela manhã. $\grave{A}$ tarde, as flores fecham-se para não mais se abrir, tenha ou não ocorrido a polinização (PINTO, 1977).

O tipo de fruto varia muito entre cultivares. O fruto maduro apresenta casca com cor variando do verde-cana ao verde-escuro, podendo ser lisa ou listrada. A cor interna da polpa pode ser amarela, rosa ou vermelha e o mesocarpo é branco.

O fruto varia de $7 \mathrm{~cm}$ até mais de $20 \mathrm{~cm}$ em diâmetro. $O$ peso dos frutos também é bastante variável. A cor das sementes pode ser branco-creme ou variar em muitas tonalidades de marrom a preta, variando também quanto ao tamanho. A forma do fruto pode ser redonda, cilíndrica ou oval. O desenvolvimento das raizes é influenciado pelo tipo e umidade dos solos (KEAY \& HEPPER, 1985; MOHR, 1986; WALTERS,1988; e COSTA, 1991).

\subsubsection{Origem e distribuição geográfica.}

Em 1857, David Livingstone, o missionário-explorador, encontrou ambas as melancias, doce (C. lanatus) e amarga (C. colocynthis) crescendo juntas na África e observou que os nativos as usavam como fonte de água na estação seca, tanto para si como para os animais (MOHR, 1986).

Pangalo citado por WHITAKER \& DAVIS (1962), fez extensivos estudos da melancia asiática. Estes estudos o convenceram de que Citrullus vulgaris seria indigena da Índia.

Segundo Gardê \& Gardê citados por CARVALHO et al. (1988), Lineu considerava a melancia como nativa do sul da Itália. Em 1828, Seringe propôs a Índia e a África como centros de origem da melancia. Por outro lado, WHITAKER \& DAVIS (1962), consideraram a melancia originária da África Tropical como de Candole já havia sugerido em 1882, e que Pangalo, na verdade, tinha localizado um centro de diversificação do gênero na Índia. 
Segundo KEAY \& HEPPER (1985), a melancia cultivada tem como centro de origem a África, tendo sido originária do Nordeste Africano passando em tempos pré-históricos a ser cultivada no Oriente Próximo, Oriente Médio, Ásia ocidental e, atravessando a savana, foi introduzida no Oeste Africano. Já MALLICK \& MASUI (1986), sugeriram que Citrullus lanatus é nativa da Africa Central (Figura.1).

Segundo JEFFREY (1975), o gênero Citrullus inclui três espécies diplóides $(2 n=22)$ originárias do sul da África. A melancia cultivada tem larga distribuição mundial. Das duas espécies selvagens, $C$. colocynthis é encontrada no norte da África e na Ásia (ZAMIR et al., 1984), enquanto C. ecirmhosus é restrita ao deserto da Namíbia (MEEUSE, 1962).

O cultivo da melancia vem dos tempos pré-históricos, como revelam as pinturas encontradas no Egito. A melancia aparece na antiga literatura árabe, em sânscrito $e$ espanhol. Aparentemente, o cultivo da melancia se deu bem cedo ao redor da Bacia do Mediterrâneo e na Índia. Atualmente, é cultivada em partes da antiga União Sovietica e em outras partes da Ásia, como China e Japão. Foi introduzida nos Estados Unidos com os colonizadores (MOHR, 1986). De um modo geral, a melancia tem uma larga distribuição de cultivo em todo o mundo.

\subsection{A Melancia no Brasil}

2.2.1. Tráfico de escravos e a introdução da melancia.

Os africanos vieram para o Brasil durante o tráfico de escravos ocorrido de 1551 a 1857 (SALDANHA, 1989).

Embora o governo português tenha tido o intuito de promover uma distribuição proporcional dos escravos recebidos de diferentes procedências africanas, pelas diversas seçōes regionais da colônia, tudo leva a crer que foi frustrado na prática, pois na Bahia é clara a maior concentração dos sudaneses, ao passo que em Pernambuco e no Rio de Janeiro prevaleceram sobretudo os negros austrais do grupo banto (RODRIGUES, 1982).

O mesmo autor chama a atenção para o fato que tão errôneo como supor que os negros bantos predominaram em todo o pais, seria concluir que só na Bahia tivessem tido ingresso os negros sudaneses.

Segundo VERGER (1987), a origem geográfica dos escravos da Bahia pode ser dividida em quatro períodos: primeiro, o ciclo da Guiné durante a segunda metade 
do século XVl; segundo o ciclo de Angola e do Congo no século XVII; terceiro o ciclo da Costa da Mina durante os três primeiros quartos do século XVIII; e o quarto ciclo da baia do Benin entre 1770 e 1850, estando ai incluído o período do tráfico clandestino.

O mesmo autor levanta uma série de relatos que de modo geral indica a pouca importância numérica dos angolanos, conguenses e moçambiquenhos na Bahia. Ressalta a ocupação de Pernambuco e do Maranhão pelos holandeses, que também dominaram a Angola entre 1641 e 1648, quando então abasteceram Pernambuco e o Maranhão de escravos angolanos e cortaram o reabastecimento da Bahia, dominada pelos portugueses.

A vinda dos africanos foi a responsável pela introdução de raças de melancia no Nordeste do Brasil (WHITAKER \& DAVIS,1962). Não só a melancia mas também um grande número de plantas trazidas pelos africanos tiveram um importante papel na alimentação, fitoterapia, forragicultura, paisagismo e vida religiosa brasileira (FREYRE, 1966; VERGER, 1987; BERG, 1991).

Como resultado de um notável paralelismo, os africanos trazidos ao Brasil, e principalmente à Bahia, souberam conservar e transmitir a seus descendentes costumes, hábitos alimentares e crenças religiosas de tal forma que reconstituíram no Brasil um ambiente africano (VERGER, 1987). Embora isso não tenha ocorrido com a mesma expressão em todo Nordeste, é fácil observar costumes africanos diferentes em diferentes regiões do Nordeste.

Dentre estes costumes, está muito certamente o cultivo da melancia, pelas propriedades fitoterapêuticas, pois as sementes têm ação purgativa e o óleo das sementes tem propriedades antiabortivas segundo VERGER ${ }^{3}$, e também como fonte de água ou como fruta, tendo o seu cultivo se disseminado por todo o Nordeste.

A Africa Central, é tida como o centro de origem da melancia por MALLICK \& MASUI (1986), região esta também de onde vieram os africanos do grupo étnico banto. Já KEAY \& HEPPER (1985), apontam o Nordeste africano como centro de origem da melancia, passando esta em seguida para o Oeste africano, região predominante dos sudaneses (Figura1).

Embora esteja clara a predominância destes dois grupos etnolingüísticos na formação da colonização brasileira, segundo SALDANHA (1989), a origem geográfica africana dos negros brasileiros não é suficientemente esclarecida.

\footnotetext{
${ }^{3}$ PIERRE VERGER. ETNÓLOGO (Estudioso da relação da Africa com a Bahia) Comunicação pessoal, 1992.
} 
Estima-se que o número de escravos trazidos para o Brasil foi de 18 milhões (SALDANHA, 1989). Este número e a origem diversificada dos mesmos, dá uma idéia da imensa possibilidade de introdução de variabilidade de melancia existente na Africa, no Brasil, particularmente no Nordeste.

2.2.2. Introdução no Nordeste e em outras regiões.

Embora a literatura agricola se refira à melancia como introduzida nos anos 50 (PINTO, 1977), esta espécie cultivada está no Brasil há seguramente 350 anos.

Os primeiros registros da introdução da melancia são iconográficos representados por telas e tapeçarias de paisagens e frutas típicas brasileiras e introduzidas, onde se registra a presença da melancia, como documentado por, Franz Post e Albert Eckhout (Figuras 2 e 3), os mais importantes artistas da corte de Maurício de Nassau (16371644), durante o dominio holandês.

Assim a cultura da melancia foi introduzida no Brasil em dois momentos distintos e em regiões bem diferentes. A primeira delas, como relatado anteriormente, se deu durante o Brasil Colônia, por escravos africanos, no Nordeste, e possivelmente, em menor número, por colonos provenientes da Península Ibérica.

No Nordeste as melancias foram cultivadas primeiro no litoral canavieiro, nas hortas que, segunto George Gardner citado por VERGER (1987), rodeavam as senzalas, seguindo dai para a região oeste e norte, chamada a região dos "currais".

No quadro colonial do fim do século XVI, havia, então, duas grandes concentrações humanas no Nordeste, ou seja Salvador e Olinda.

Os baianos foram conquistando o Recôncavo e em seguida seguiram em direção ao norte até a divisa com Pernambuco - a foz do São Francisco, por onde se processou a marcha de ocupação do Oeste. Em 1589, iniciou-se a conquista do norte, e a partir de Olinda se chegou à Paraiba, Rio Grande do Norte, Ceará e Maranhão (PORTO, 1964).

Segundo ANDRADE (1975), o espaço foi organizado a partir dos interesses dos grandes proprietários ou sesmeiros que, vivendo em Olinda e Salvador, 

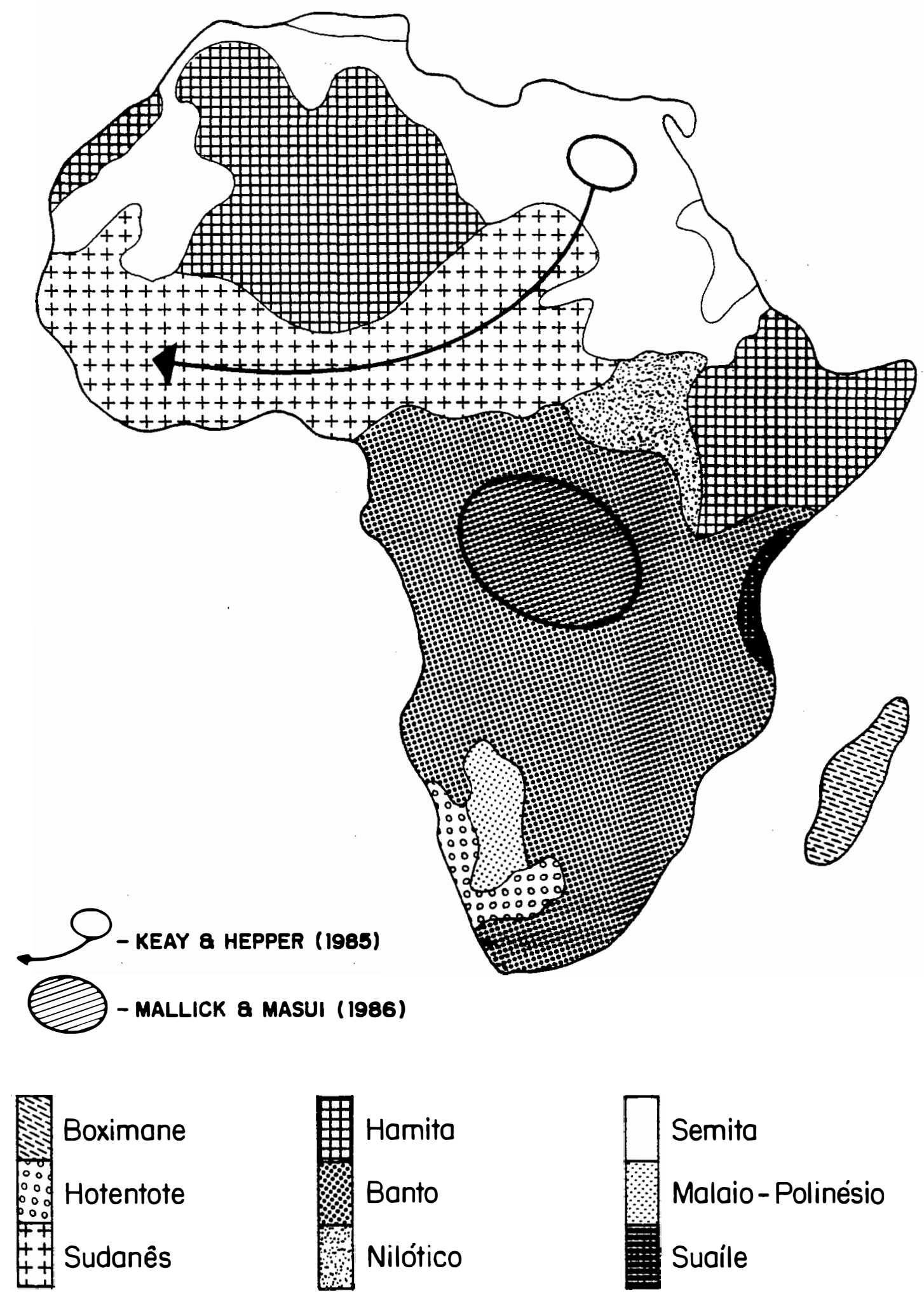

Figura 1. Distribuição dos principais grupos etnolingüísticos africanos: adaptada de Ciência Hoje, V.9, 1989, e centros de origem da melancia na África, segundo KEAY \& HEPPER (1985) e MALLICK \& MASUI (1986). 

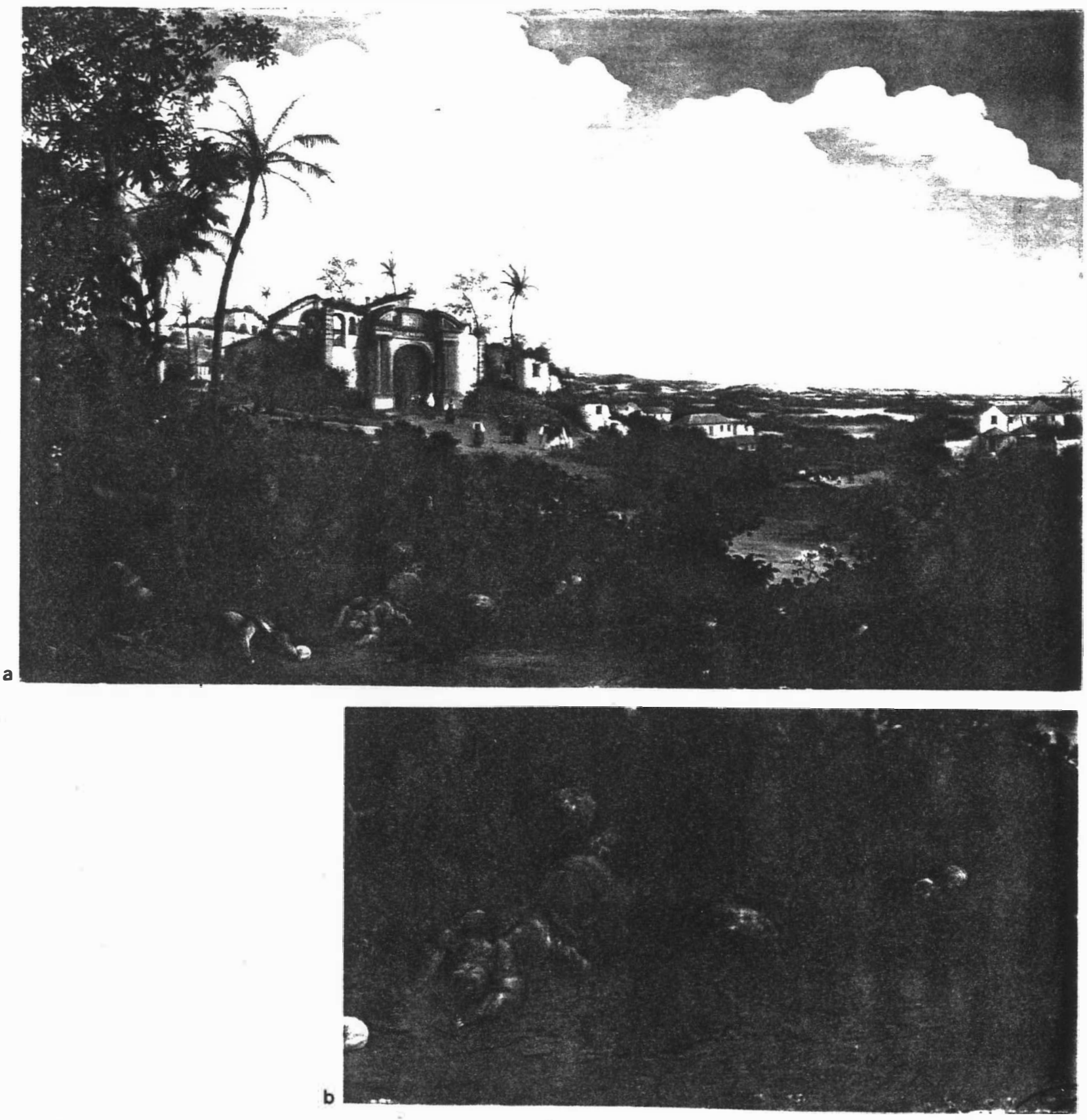

Figura 2. (a)Vista de Olinda, reprodução do quadro de Franz Post, onde pode ser observada a representação da melancia. Século Xvll. (b) Detalhe da representação da melancia. 


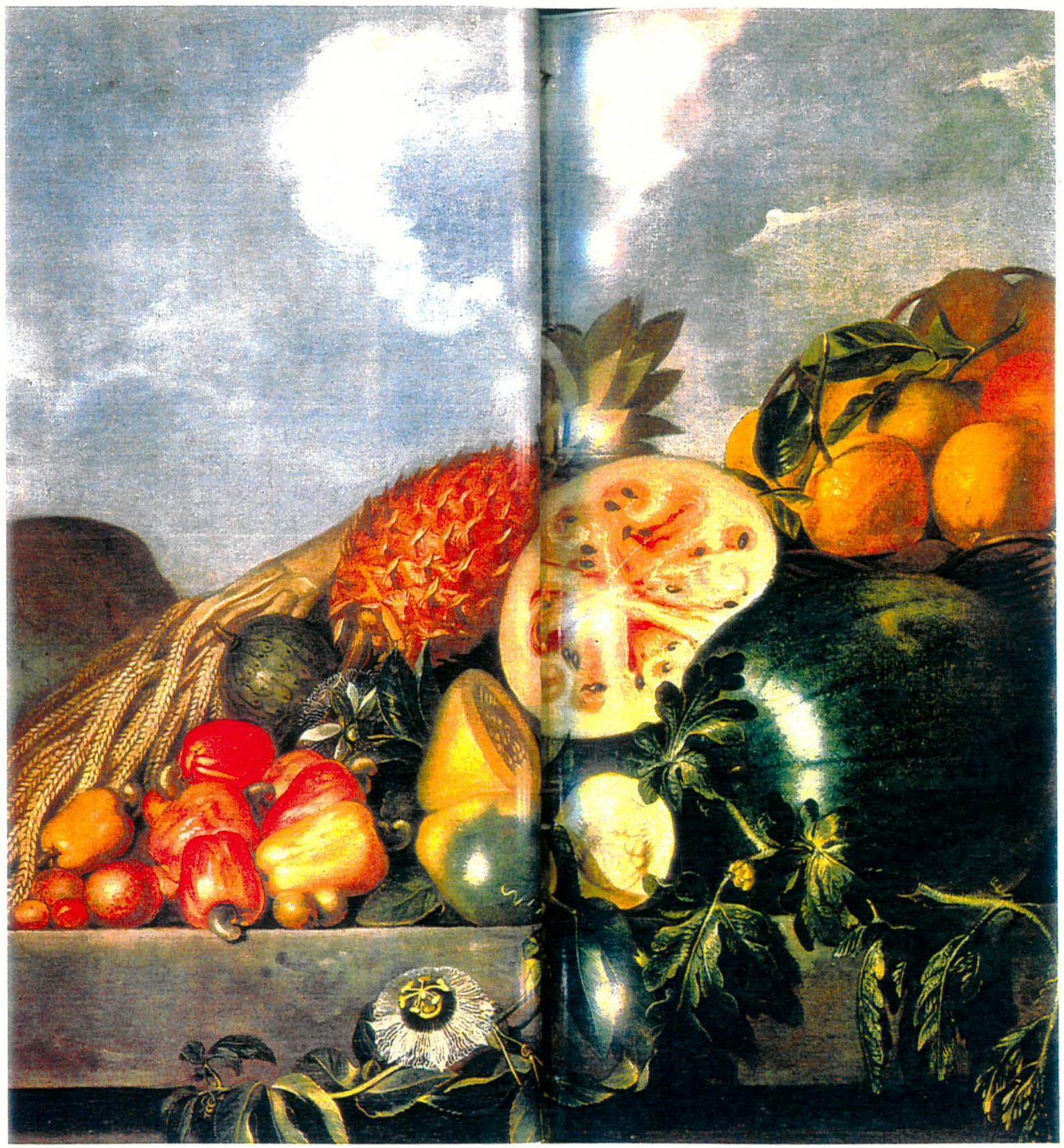

Figura 3. Natureza morta de Albert Eckhout, representando frutos encontrados no Nordeste do Brasil, dentre eles a melancia. Século XVII. 
conseguiram dos governadores, grandes doações de terras, que depois eram divididas em sítios e entregue a vaqueiros que se estabeleciam no sertão para cuidar do gado com auxilio de alguns escravos ou moradores livres.sombra dos "currais". Ocupava pequenas áreas limitadas por cercas ou valados para impedir a passagem dos animais e era realizada visando ao abastecimento da população local de influência dos "currais" (ANDRADE, 1980).

Essa agricultura era normalmente desenvolvida nos locais mais úmidos, mais favoráveis, como os leitos dos rios, as "serras frescas", nos melhores solos e restringiase ao cultivo de milho, feijão, mandioca e, às vezes, melancia e melão (SILVA, 1994).

Segundo QUEIROZ (1993) a melancia introduzida no Brasil vem sendo cultivada até hoje na agricultura de sequeiro no Nordeste do Brasil, em pequenos estabelecimentos agrícolas.

O mesmo autor observa que o cultivo utilizando variedades locais, a larga diversidade edafoclimática, cultural e sócio-econômica e as formas de utilização do espaço rural praticada pelos pequenos e médios produtores rurais do Nordeste, vem permitindo que um número expressivo de espécies cultivadas, além da melancia, seja exposta ao processo de seleção natural ao longo dos anos (QUEIROZ, 1992).

O cultivo da melancia, teve um segundo momento de introdução, dessa vez como monocultura, utilizando os chamados insumos modernos, iniciada utilizando cultivares melhorados, americanas e japonesas de acordo com PINTO (1977), no Estado de São Paulo, no município de Americana, espalhando-se depois para os outros municípios. As primeiras introduções foram variedades americanas como Florida Favorite, Congo e Fair Fax cultivadas até 1955, sendo que este ano é marcado pela introdução do cultivar Charleston Gray. No ano de 1960, surgiram os tipos Japoneses como Yamato Sato e Omaro Sato.

$\mathrm{Na}$ década de 70, teve inicio o plantio dos cultivares melhorados em escala comercial no Nordeste. Estes eram cultivados nas áreas irrigadas do Vale do São Francisco, principalmente no Projeto de Irrigação Bebedouro, localizado no municipio de Petrolina, utilizando então o cultivar Charleston Gray que foi utilizado até 1985, segundo Dias $^{4}$, quando devido ao problema de podridão apical começou a ser substituído pelo cultivar Crimson Sweet, que se mantem até hoje como o mais plantado. Das áreas irrigadas no Nordeste a melancia passou a ser cultivada no Centro Oeste.

\footnotetext{
${ }^{4}$ DIAS, R. C. S. (CENTRO DE PESQUISA AGROPECÚARIA DO TRÓPICO SEMI-ÁRIDO - EMBRAPA) Comunicação pessoal, 1993.
} 
O estudo inicial desses materiais do Nordeste, segundo QUEIROZ (1993), mostrou grande variabilidade para diversas características como cor da casca, cor da polpa, cor da semente, tamanho e forma de fruto além do brix. ROMÃO et al. (1994a) encontraram variação para padrão de casca, espessura de casca, cor externa predominante, formato e peso de fruto, cor da polpa, espessura da polpa, brix, cor, tamanho e número de sementes.

Uma particularidade no cultivo tradicional de melancia em algumas partes do Nordeste, é a existência de populações semeadas pelos agricultores e populações sub-espontâneas resultantes da germinação de sementes, que permaneceram no solo a

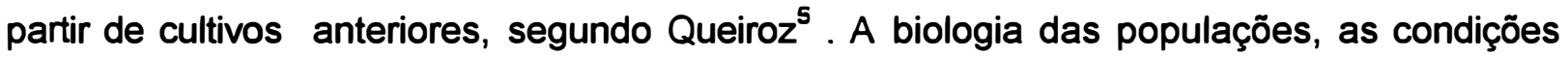
climáticas e ecológicas e as formas de cultivo nas áreas tradicionais, criam as condições necessárias para a manutenção das populações sub-espontâneas (ROMÃO, et al. 1994b).

2.3. Fluxo gênico e biologia de populações de cucurbitáceas.

O fluxo gênico, em plantas, ocorre através da dispersão de sementes e pólen. Estudos de movimento e germinação de sementes (HARPER \& OGDEN, 1970), e de movimentação de pólen (LEVIN \& KERSTER, 1975) mostraram que o modelo de dispersão é restrito e dependente do agente dispersor e da morfologia das sementes e do grão de pólen. Outros estudos associam morfologia e fisiologia, mais especificamente dormência, e sua relação com o tipo de dispersão de sementes (REIS \& MARTINS, 1989, VIEIRA \& MARTINS, 1991).

São características da biologia reprodutiva das Cucurbitáceas, serem plantas alógamas, monóicas, sem depressão por endogamia, com alta taxa de endogamia e com fluxo de pólen restrito e não direcional.

ALLARD (1971), define as cucurbitáceas como sendo plantas que devido a fatores biológicos e econômicos, tal como o grande espaço ocupado pelas plantas e a necessidade de poucas plantas para satisfazer as necessidades dos agricultores, devem ter-se mantido em pequenas colônias, tanto na natureza como em cultivo.

JENKIS (1942), estudando pepino encontrou uma taxa de autofecundação de 30 a $35 \%$.

\footnotetext{
${ }^{5}$ QUEIROZ, M. A. de. (CENTRO DE PESQUISA AGROPECÚARIA DO TRÓPICO SEMI-ÁRIDO EMBRAPA) Comunicação pessoal, 1993.
} 
Segundo HANDEL (1983), o fluxo de pólen em pepino (Cucumis sativus) segue a distribuição leptocúrtica, com o fluxo de pólen se restringindo de dois a três metros. Os resultados mostraram porém que populações próximas podem ter diferentes dinâmicas de fluxo de pólen e que a migração do pólen pode ser direcional, sem a influência de pressões de seleção, estando mais em função dos polinizadores.

Segundo EPLEING \& DOBZAHNSKY (1942), o fluxo restrito de pólen parece ser o maior componente de adaptação local em plantas e responsável pela heterogeneidade das frequências gênicas.

Estudos mostram que diferenças na dinâmica de fluxo de pólen podem ser um fator de mudança evolutiva. Alguns casos são conhecidos onde populações próximas têm diferentes fluxos de pólen. ANTONOVICS (1968), estudando populações em áreas de minas, sugere que os genes para auto-fertilidade devem estar associados a genes de tolerância, e que a relação entre autofecundação e fluxo gênico não está bastante clara. LEVIN \& KERSTER (1975) observaram que, quando ocorre migração, o modelo de recebimento de genes via pólen afeta notavelmente a taxa de substituição, se o novo gene for vantajoso, e o equilibrio for prejudicial para o novo gene.

Os estudos conduzidos em Israel com materiais de C. colocynthis e $C$. lanatus por ZAMIR et al., (1984), e no Brasil por, ARAÚJO et al., (1987) e DIAS et al., (1989), mostraram a existência de genes de resistência ao oídio, e ao virus (PRSV-W), em materiais conhecidos localmente como "melancia-de-cavalo" ou "melancia-de-porco".

FULKS et al. (1979), por outro lado, relataram a ocorrência de hibridação natural entre espécies de Citrullus, no Arizona, SINGH (1978) na Índia, MAHESHWARI, (1978) em Gana, e ZAMIR et al., (1984), observaram a introgressão de alelos de $C$. colocynthis em raça local de $C$. lanatus.

ASSIS, (1994) sugere utilizar para a melancia de cavalo a classificação C. lanatus var. citroides.

Os modelos locais de adaptação e diferenciação das populações contribuem para a grande habilidade destas em persistir em diferentes ambientes. QUEIROZ et al. (1994), estudando 69 populações de melancia de quatro regiões do Nordeste quanto a resistência à Didymella bryoniae, fungo que causa a doença denominada micosferela, sugerem uma relação entre a ecologia dessas regiões e a freqüência de ocorrência de populações com resistência à doença. 
2.4. Uso do germoplasma e medidas de variabilidade

2.4.1. Recursos genéticos e caracterização de variabilidade

O IBPGR (1991) considera recursos genéticos como sendo o germoplasma de plantas, animais e microorganismos, contendo caracteres utilitários de valor atual ou potencial.

O trabalho com recursos genéticos, de maneira geral, se divide em cinco etapas: coleta, conservação, multiplicação, caracterização e avaliação.

Segundo WILLIAMS (1984), o maior problema enfrentado pelo IBPGR é a falta de informação da amplitude e modelo de variação existente nas populações, o grau de perigo de perda dessa variabilidade e a falta de informação sobre o quanto dessa variabilidade esta presente nas coleções de germoplasma.

Para que o uso do germoplasma seja estimulado, é necessário identificar suas características e potencialidades utilitárias. Para tanto, é importante a organização e validação das informações obtidas através do uso de descritores. Os descritores podem ser classificados nos seguintes tipos: (i) de identificação ou passaporte; (ii) de caracterização; (iii) de avaliação; e (iv) de manejo ou monitoramanto (VILELAMORALES \& MENDES, 1983).

A caracterização e avaliação consistem em cinco etapas: 1 identificação botânica; 2 - elaboração dos dados de passaporte (ligado a coleta); 3 caracterização, propriamente dita; 4 - avaliação preliminar; 5 - avaliação aprofundada.

A caracterização, como originalmente proposta por SIMMONDS (1979a), está assentada em características botânicas básicas de amostras que podem ser facilmente observadas visualmente ou facilmente mensuráveis e que tenham uma herdabilidade razoavelmente alta. Já a avaliação preliminar inclui o registro de um número limitado de características adicionais que são tidas, pelos que trabalham com a cultura, como úteis para o melhoramento ou cultivo. Estas também incluem aquelas que podem ser vistas ou mensurados facilmente. Não há delimitação clara entre os dois conceitos ( WILLIAMS,1984).

A avaliação preliminar é essencial para a utilização efetiva dos materiais mantidos em bancos de germoplasma. Esta avaliação, segundo FRANKEL \& SOULE (1981) pode consistir, em uma simples descrição do lugar de origem e algumas características morfológicas e descrições fenológicas ou pode se estender a características fisiológicas, 
genéticas, bioquímicas e de reação à doenças e pragas dentre outras. Estes autores ainda observam que qualquer que seja o nivel deve-se ter uma motivação relacionada com a utilização, seja em área de pesquisa, ou em programas de melhoramento.

A caracterização e avaliação da diversidade fenotípica entre e dentro de regiões, deve ser um dos mais importantes mecanismos para estimular a conservação e uso dos recursos genéticos (PERRY et al., 1991).

O número de informações sobre as populações mantidas em bancos de germoplasma nacionais, é muito baixo (VILELA-MORALES \& MENDES, 1983). Porém, a situação mundial é também bastante crítica. Estima-se que das 2.000 .000 populações mantidas em bancos mundiais, $65 \%$ estão sem caracterização e $95 \%$ sem dados de avaliação. Evidentemente, a falta de informação afeta a utilização do germoplasma, por isto a taxa de utilização não passa de 4\% (PEETERS \& WILLIAMS, 1984; GIACOMETTI, 1988).

De maneira geral vários autores discutem a ameaça de perda de recursos genéticos principalmente pela substituição das variedades locais ou etnovariedades por materiais melhorados (FRANKEL \& BENNETT, 1970; FRANKEL \& SOULE, 1981; HOLDEN,1984; BREESE, 1989; CLARK \& JUMA,1991).

Por outro lado, outros autores chamam atenção para o fato de que a simples coleta e conservação ex situ de etnovariedades não é suficiente para evitar erosão genética. Para assegurar a conservação seria necessário viabilizar o uso dessas variedades através de melhoramento in situ (CLEVELAND et al., 1994).

No caso especifico do Nordeste brasileiro QUEIROZ, (1993) observou que a forma atual de manejo dos recursos naturais, aliada às freqüentes secas, inundações devido à construção de barragens, o êxodo rural e o fomento à utilização de sementes de variedades melhoradas, vem induzindo a extinção de raças tradicionais e conseqüentemente de muitos genes úteis para os programas de melhoramento.

Tentando evitar esta erosão genética, o CPATSA, iniciou, em 1985, a coleta de amostras de sementes de várias culturas, entre elas a melancia na Bahia, Piauí, e mais especialmente em Pemambuco. Outras expedições de coleta foram realizadas em 1991 e 1992, tomando-se por base os municipios de Jacobina-BA, Irecê-BA, Tacaimbó-PE, Teresina-PI e, Pastos Bons-MA. Destas coletas resultaram 456 populações de melancia (RAMOS \& QUEIROZ, 1992; COSTA, 1992; QUEIROZ, 1993).

Um ponto de estrangulamento no uso intensivo destes materiais coletados refere-se a pouca ou nenhuma informação descritiva dos mesmos. Dessa 
maneira, o incremento das atividades de caracterização e avaliação do germoplasma deve se impor entre as prioridades na abordagem e manejo dos recursos genéticos (VALLS, 1988).

Vale a pena ressaltar que o baixo uso do germoplasma, no caso do Brasil, está fortemente associado ao número pequeno de melhoristas, de sua concentração em poucas culturas, além da resitência destes na utilização dos bancos de germoplasma, como identificado por NASS et al., (1993).

O IPGRI (ex-IBPGR) conta com lista de descritores, para um número expressivo de culturas enquanto que para outras, como é o caso da melancia (Citrullus lanatus) tal lista não existe.

\subsubsection{Estudo da Variabilidade em Germoplasma de Cucurbitáceas.}

Objetivando a pronta utilização de materiais exóticos nos programas de melhoramento de cucurbitáceas, vem sendo feita, nos mais diversos gêneros da familia, avaliações para características especificas.

Nove populações de melancia (Citrullus lanatus), foram avaliados para 14 características sendo estimados os coeficientes de variação genotípico e fenotípico. Os coeficientes foram altos para número de frutos/planta, peso médio de frutos, número de sementes/fruto, peso de 100 sementes e produção/planta. A produção foi correlacionada com comprimento do ramo $(r=0,47)$, número de ramos/planta $(0,75)$, peso de fruto $(0,88)$, comprimento $(0,63)$ e circunferência $(0,61)$. Estas características mostraram alta herdabilidade e alto ganho genético e são recomendadas como critério de seleção (LALTA PRASAD et al.,1988).

WHANG \& ZHANG (1988), estudaram comparativamente 10 variedades de melancia introduzidas da Africa e um cultivar comercial, quanto a : morfologia, biologia, caracteres agronômicos e de resistência à doenças por três anos. As populações africanas diferiram do cultivar comercial em muitas características e uma grande diversidade foi encontrada entre eles. As variedades africanas mostraram potencial para alta produção e são sugeridas como fonte de germoplasma para o melhoramento, especialmente para resistência à doenças, alta produção e longo tempo de armazenamento.

A partir do germoplasma de melancia inicialmente coletado na região Semi-Árida, foi dado inicio ao BAG de cucurbitáceas do CPATSA e as avaliações quanto a resistência ao oídio e ao virus PRSV-W, (WMV-1). 
No trabalho de avaliação realizado inicialmente identificaram-se sete populações com número reduzido ou sem nenhuma infecção (ARAÚJO et al., 1987). SOUZA et al. (1988), avaliaram oito acessos e dois cultivares comerciais quanto a resistência ao oídio e sugeriram a população 85-030 e 87-029 como fontes de resistência. DIAS et al. (1989); avaliaram nove tratamentos quanto à suscetibilidade ao oídio. Foram identificadas as populações 88-072, 88-071 e 88-027 que apresentaram 4,66\%, 3,66\% e 1,66\% de infecção respectivamente, sendo estes materiais indicados como fontes de resistência.

DIAS \& QUEIROZ (1991), avaliaram cinco grupos de progênies da geração $F_{5} R C_{2}$ quanto à tolerância ao oídio e às características de fruto em duas epócas. Várias progênies foram identificadas como homozigóticas para cor de casca, sendo que para cor de polpa e brix ainda foi observada grande variação. Entretanto 48 progênies apresentaram brix superior a nove.

ARAÚJO \& SOUZA (1988), avaliaram 28 populações de melancia quanto à resistência ao PRSV e sugerem que uma das populações estudadas apresentou resistência mecânica ao vetor do vírus. ARAÚJO et al. (1989), avaliaram três populações e cinco linhas obtidas do cruzamento de populações locais com cultivares comerciais. Destacou-se a linha 88-127, resultante do cruzamento de Charleston Gray com Ouricuri, que apesar de apresentar sintomas esparsos do mosaico, teve grande desenvolvimento vegetativo e alta produtividade.

QUEIROZ et al. (1994), avaliaram 69 populações de melancia coletadas em quatro áreas razoavelmente isoladas no Nordeste: Caatinga do Moura ( Município de Jacobina,BA), Irecê (BA), Petrolina (PE)/ Juazeiro (BA), Pastos Bons (MA), englobando municípios vizinhos, para reação a Didymella bryoniae e foram encontradas 1 , 3,5 e 15 plantas resistentes nas quatro regiões, respectivamente.

Trabalhando com 156 populações de chuchu (Sechium edule Sw.) da América Central, ENGELS (1983), estudou 11 caracteres de frutos fisiologicamente maduros. Observou que a variação para todos os caracteres estudados era contínua.

SIROHI (1991) relatou os usos, a diversidade morfológica e sensibilidade ao frio em melão de São Caetano (Momordica charantia), enquanto SHARMA \& DHANKAR (1990), em avaliação feita em 35 genótipos de cabaça (Lagenaria siceraria Standl.) indicaram os genótipos mais precoces e com maior produção.

Avaliando 24 acessos de abóbora (Cucurbita moschata) para precocidade (número de dias para o florescimento), número de flores femininas e 
masculinas, comprimento, largura, peso de fruto, número de frutos/planta, espessura de polpa e número de sementes por fruto foram indicadas as populações mais precoces e produtivas (DEVI et al, 1989).

FARBER (1990), estudou 92 populações de pepino (Cucumis sativus) em casa de vegetação, e identificou materiais com poucas ramificações laterais, tendência à partenocarpia, precocidade, alta produção e resistência à doenças, sendo selecionadas 22 populações consideradas promissoras para programas de melhoramento. ABUSULEHA \& DULTA (1990), estudaram 75 populações de pepino (Cucumis sativus) durante 1987 e obtiveram estimativas de variabilidade, herdabilidade e ganho genético para diversas características. 


\section{MATERIAL E MÉTODOS}

\subsection{Material}

\subsubsection{Regiões estudadas}

As regiões onde foram realizadas as coletas, estão localizadas no Médio Sertão Maranhense que é uma região mais úmida, na Depressão Sertaneja (SILVA et al.,1993) uma região semi-árida e na região Central da Bahia que é uma região de umidade intermediária (Figura 4).

As três regiōes foram escolhidas com base em três critérios : 1 - por serem regiões de referência quanto ao cultivo de cucurbitáceas; 2 - por estarem bastante - distanciadas entre si; e, 3 - por serem distintas com relação à ecogeografia e representarem áreas de ecologia semelhante a outras regiões do Nordeste.

\subsubsection{Germoplasma Utilizado}

O germoplasma foi coletado na forma de sementes e frutos e foi multiplicado durante o segundo semestre de 1992 no CPATSA, campo experimental de Bebedouro-PE. Estes materias fazem parte do programa "Recursos Genéticos e Melhoramento de Cucurbitáceas para áreas irrigadas do Nordeste Brasileiro" que vem sendo desenvolvido desde 1990, pelo Centro de Pesquisa Agropecuária do Trópico SemiÁrido (CPATSA).

Para a multiplicação foram utilizadas 15 plantas por população, fazendo-se polinização manual com controle gamético feminino. Após a colheita, as sementes foram mantidas com a identidade dos frutos e dentro de cada acesso foram tomados 3 frutos (ROMÃO et al., 1994c), tendo sido este o número mínimo de frutos com polinização controlada dentre as populações. Retiraram-se 20 sementes por fruto, necessárias para a formação do "bulk" de 60 sementes para a implantação dos experimentos.

O germoplasma utilizado, foi coletado em roças, escolhidas ao acaso, em diversas localidades das três regiões. Foram estudadas 13 populações de cada região 
(Tabela 1). As 39 populações utilizadas nesse estudo representam cerca de $10 \%$ do total de populações de melancia do Banco Ativo de Cucurbitáceas-CPATSA.

\subsubsection{Local do Experimento}

O presente trabalho foi conduzido no município de Juazeiro, Estado da Bahia, situado na latitude de $9^{\circ} 22^{\prime} \mathrm{S}$ e $40^{\circ} 36^{\prime} \mathrm{W}$ de longitude, $375 \mathrm{~m}$ de altitude, na Estação Experimental de Mandacaru pertencente a EMBRAPA/CPATSA, nos meses de agosto a dezembro de 1993.

A Estação Experimental está localizada numa área de solos grumossólicos. São solos argilosos, profundos $(150 \mathrm{~cm})$ desenvolvidos a partir de material calcário, de reação alcalina. O clima segundo classificação de Koppen, corresponde a BSh'W, quente com chuvas irregulares. A umidade relativa do ar varia pouco estando em torno de $60 \%$. A temperatura média mensal é de $26,3^{\circ} \mathrm{C}$. A temperatura máxima absoluta

- atinge $39,1^{\circ} \mathrm{C}$ (outubro) e a minima absoluta $12,1^{\circ} \mathrm{C}$ (julho). A precipitação média anual varia de $150 \mathrm{~mm}$ a $800 \mathrm{~mm}$ (LEITE et al. 1971). 


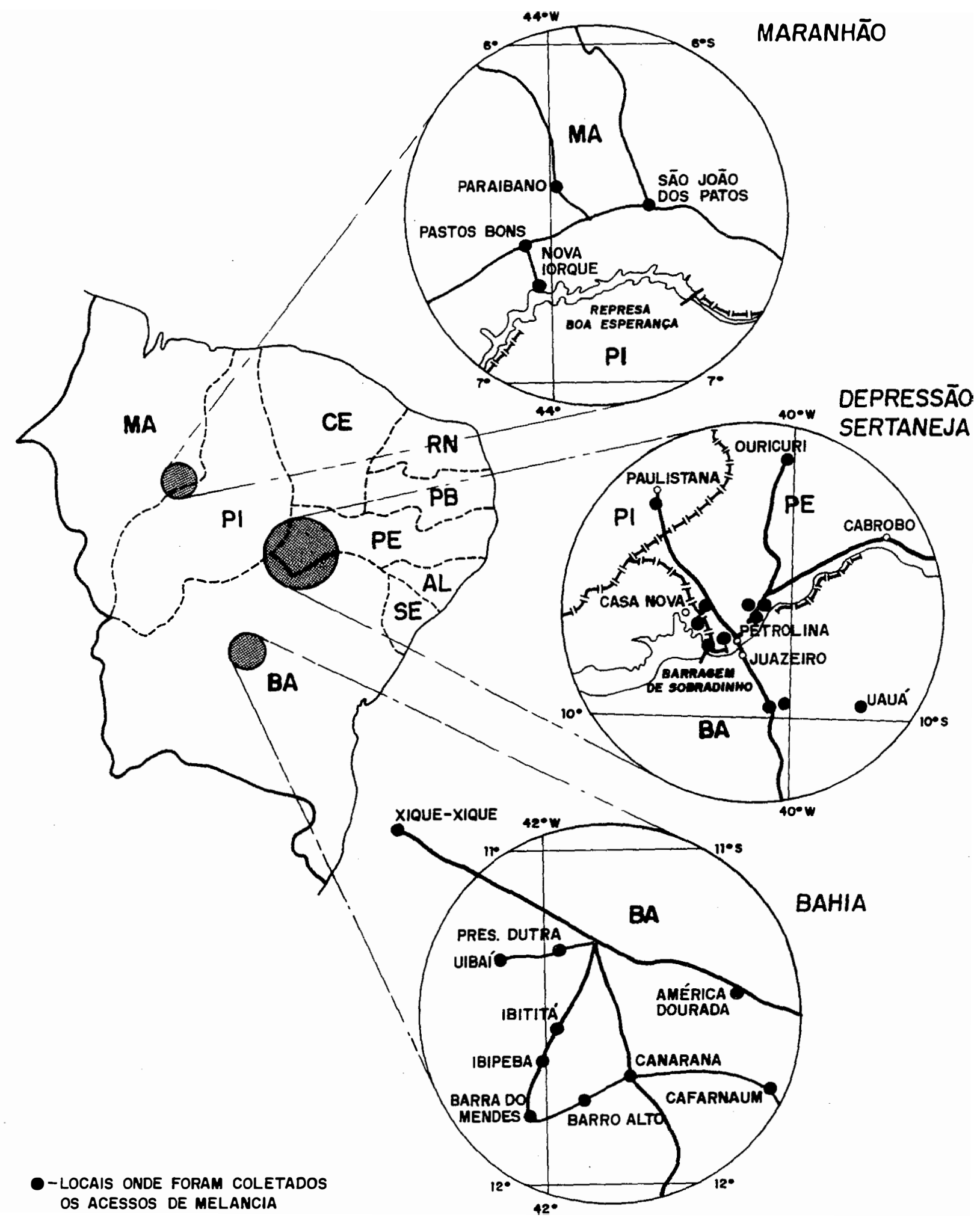

Figura 4. Localização geográfica das três regiões estudadas e locais de coleta de amostras de melancia. Detalhes da localização dos municipios base da coleta nas regiões 1,2 e 3. 
Tabela 1. Relação das populações de melancia, com os respectivos números de tratamentos, região/procedência (região/município) e o número no Banco Ativo de Germoplasma - BAG do CPATSA.

\begin{tabular}{|c|c|c|}
\hline $\begin{array}{l}\text { Número do } \\
\text { tratamento }\end{array}$ & Região / Procedência & Número no BAG \\
\hline 01 & MA* - São João dos Patos & $91-083$ \\
\hline 02 & MA - Pastos Bons & $91-073$ \\
\hline 03 & MA São João dos Patos & $91-093$ \\
\hline 04 & MA - Pastos Bons & $91-072$ \\
\hline 05 & MA - São João dos Patos & $91-087$ \\
\hline 06 & MA - Pastos Bons & $91-071$ \\
\hline 07 & MA - Nova lorque & $91-122$ \\
\hline 08 & MA - São João dos Patos & $91-104$ \\
\hline 09 & MA - Nova lorque & $91-081$ \\
\hline 10 & MA - São João dos Patos & $91-107$ \\
\hline 11 & MA - Pastos Bons & $91-074$ \\
\hline 12 & MA - Paraibano & $91-078$ \\
\hline 13 & MA - São João dos Patos & $91-084$ \\
\hline 14 & DS - CPATSA - 02 & $85-030$ \\
\hline 15 & DS - Uauá & $87-022$ \\
\hline 16 & DS - Acauã - 01 & $87-029$ \\
\hline 17 & DS - CPATSA - 13 & $85-041$ \\
\hline 18 & DS - Barreiro - 01 & $87-015$ \\
\hline 19 & DS - Massaroca & $87-005$ \\
\hline 20 & $\begin{array}{l}\text { DS - Lagoa dos Cavalos - } \\
01\end{array}$ & $87-018$ \\
\hline 21 & $\begin{array}{l}\text { DS - Lagoa dos Cavalos - } \\
02\end{array}$ & $87-010$ \\
\hline 22 & DS - CPATSA C & $87-017$ \\
\hline 23 & DS - Uauá & $87-025$ \\
\hline 24 & DS - Riacho do Sobrado & $87-013$ \\
\hline 25 & DS - Campo da SPSB & $87-019$ \\
\hline 26 & DS - Massaroca & $87-008$ \\
\hline 27 & BA - América Dourada & $91-064$ \\
\hline 28 & BA - Barro Alto & $91-026$ \\
\hline 29 & BA - Barra & $91-038$ \\
\hline 30 & BA - Itaguaçu & $91-042$ \\
\hline 31 & BA - São Gabriel & $91-001$ \\
\hline 32 & BA - Cafamaum & $91-061$ \\
\hline 33 & BA - Xique - Xique & $91-031$ \\
\hline 34 & BA - Itaguaçu & $91-043$ \\
\hline 35 & BA - Presidente Dutra & $91-002$ \\
\hline 36 & BA- Xique - Xique & $91-030$ \\
\hline 37 & BA - Ibipeba & $91-011$ \\
\hline 38 & BA - Canarana & $91-028$ \\
\hline 39 & BA- Ibititá & $91-008$ \\
\hline
\end{tabular}

\# MA - Maranhão, DS - Depressão Sertaneja, BA - Região Central da Bahia 


\subsection{Métodos}

3.2.1. Caracterização morfológica, fisiológica e fenológica .

Para esta caracterização foram realizados dois experimentos. No experimento 1 as populações foram avaliadas para características de plântula. As populações foram semeadas diretamente no campo em parcelas com quatro plantas e parcela útil de quatro plantas num espaçamento de $3 \mathrm{~m} \times 1 \mathrm{~m}$.

No experimento 2 foram avaliados os dados vegetativos, de inflorescência, de fruto e de sementes. Antes da implantação do experimento no campo, as sementes foram postas a germinar em telado, em bandejas de isopor do tipo Plantmax, contendo vermiculita como substrato. As plântulas foram transplantadas quando contavam com duas folhas primárias. A parcela experimental total foi constituida de uma linha com oito plantas, num espaçamento de $3 \mathrm{~m} \times 1 \mathrm{~m}$, sendo a parcela útil de quatro plantas.

Os tratos culturais foram os exigidos pela cultura nas condições de cultivo. Os tratos fitossanitários foram preventivos.

O delineamento experimental utilizado foi de blocos ao acaso com quatro repetições sendo 39 tratamentos, 13 por região.

A caracterização foi feita por indivíduo, baseada nas seguintes

variáveis:

\section{- Dados da Plântula -}

1 - largura do cotilédone (LC), de um cotilédone por planta, nove dias após a germinação.

2 - comprimento do cotilédone (CC), de um cotilédone por planta, nove dias após a germinação.

\section{- Dados Vegetativos -}

3 - tamanho de folha (TF), média de três folhas de cada planta, tomando o comprimento longitudinal, 70 dias após o plantio

4 - tamanho de peciolo (TP), média de três folhas de cada planta, 70 dias após o plantio.

5 - comprimento do intemó $(\mathrm{Cl})$, tomado 15 dias após a abertura da primeira flor feminina. Média do comprimento dos três primeiros nós.

6 - diâmetro do ramo principal (DRP), obtido com paquímetro na base da planta, 70 dias após o plantio. 
7 - número de ramos (NR), contado a $1 \mathrm{~m}$ do colo da planta, 70 dias após o plantio.

- Dados de Inflorescência -

8 - início do florescimento (IFL), número de dias entre a semeadura até que um mínimo de $50 \%$ das plantas da parcela apresentem flores femininas.

9 - distância da primeira flor feminina (DPFF), obtida medindo-se a distância do colo até a primeira flor feminina.

- Características do Fruto - tomadas de um fruto maduro por planta-

10 - peso do fruto (PFR), expresso em $\mathrm{g}$.

11 - formato do fruto (FFR) .

1 - redondo

3 - oval

5 - cilíndrico

7 - longo

12 - cor extema predominante (CEP).

1 - verde claro

3 - verde médio

5 - verde escuro

13 - padrão de casca (PC).

1 - com listras

3 - rendilhado

5 - mosqueado

7 - sem listras

14 - cor das listras (CL).

3 - verde clara

5 - verde média

7 - verde escura

15 - espessura das listras (EL).

3 - estreitas

5 - médias

7 - largas

16 - comprimento do fruto(CFR), expresso em cm. 
17 - diâmetro do fruto (DFR), expresso em $\mathrm{cm}$.

18 - espessura de casca (EC), expresso em $\mathrm{cm}$.

19 - espessura de polpa (EP), expresso em $\mathrm{cm}$.

20 - cor da polpa (CP).

1 - branca

2 - amarela

3 - rosa alaranjado

4 - rosa

5 - rosa escuro

6 - vermelha claro

7 - vermelha

8 - vermelha intensa

21 - textura da polpa (TXP).

3 - firme

5 - meio fibrosa

7 - fibrosa

22 - Brix (B), obtido com refratômetro de bolso.

23 - dureza da casca (DC).

$$
\begin{aligned}
& 3 \text { - frágil } \\
& 5 \text { - média } \\
& 7 \text { - dura }
\end{aligned}
$$

- Semente - avaliadas de um fruto maduro por planta -

24 - número de sementes por fruto (NS).

25 - peso de 50 sementes (P50S), expresso em g.

26 - tamanho (TS), média de três sementes por fruto, expresso em $\mathrm{mm}$. 
3.2.2. Observações ecogeográficas e de sistema de cultivo.

As informações sobre solos, procedência e algumas relacionadas aos sobre sistema de cultivo foram obtidas através de consultas a agricultores e técnicos da região 2 e também foram utilizadas informações reunidas durante a coleta.

Foram levantados, na literatura, alguns aspectos sobre o tráfico de escravos e história da colonização do Nordeste.

As informações pluviométricas foram obtidas com base nos trabalhos de HEARGREAVES (1973) e PAZ (1990), que estudaram as distribuições de chuvas na região Nordeste num período de 35 a 50 anos.

Algumas informações sobre fenologia e comportamento da cultura foram obtidas nos experimentos realizados e em observações em roças de agricultores.

\subsubsection{Metodologias Estatísticas}

\subsubsection{Caracteres qualitativos}

Para cada população foram estudadas as variáveis qualitativas: formato de fruto (FFR), cor externa predominante (CEP), padrão de casca (PC), cor das listras (CL), espessura das listras (EL), cor de polpa (CP), textura de polpa (TXP) e dureza de casca (DC). Para cada variável foram estabelecidas categorias e observada a freqüência de cada categoria para as regiōes: Maranhão, Depressão Sertaneja e Bahia.

\subsubsection{Caracteres quantitativos - análises univariadas.}

A equação do modelo estatístico para as médias das observações tomadas no experimento é a seguinte :

$$
Y_{i j k}=m+b_{k}+R_{j}+P_{i(j)}+e_{i j k}(1)
$$

onde:

$$
\begin{aligned}
Y_{i j k}= & \text { observação fenotípica média, da população } i \text {, oriunda da região } j, \\
& \text { na repetição } k . \\
\mathbf{m}= & \text { média geral do caráter. } \\
\mathbf{b}_{k}= & \text { efeito ambiental da repetição } k \text {; sendo este efeito uma variável } \\
& \text { aleatória com média } 0 \text { e variância } \sigma^{2}{ }_{b} ; \\
\mathbf{R}_{j}= & \text { efeito da região } j ; j=1,2,3 ;
\end{aligned}
$$


$P_{i(j)}=$ efeito genético da população $i$, na região $j=1$; sendo este efeito uma variável aleatória com média 0 e variância $\sigma_{P(j)}^{2}: i=1 . .13$;

$e_{i j k}=$ efeito da interação da população $\mathrm{i}$, da região j, na repetição $\mathbf{k}$; sendo este efeito uma variável aleatória com média 0 e variância $\sigma^{2}$.

Neste modelo supõe-se que em cada região a variável aleatória $\mathbf{P}_{\mathrm{i}(0)}$ pode ter uma variância diferente.

As análises de variância foram realizadas, de acordo com o modelo descrito em (1), para as seguintes variáveis: comprimento do cotilédone, largura do cotilédone, comprimento do intemó, distância para a primeira flor feminina, diâmetro do ramo principal, tamanho do peciolo, número de ramos, tamanho de folha, peso de fruto, diâmetro do fruto, comprimento do fruto, espessura de casca, espessura de polpa, brix, número de sementes por fruto, peso de 50 sementes, tamanho da semente.

Entre as variáveis estudadas foi observada a freqüência de dados perdidos e detectou-se que, das 17 variáveis estudadas, 11 tinham parcela perdida e dentre estas, dias para o florescimento, foi a variável com maior índice de perda, pois apresentou três parcelas com dados perdidos em diferentes blocos e populações. Devido à complexidade do processo de estimação e teste utilizando dados desbalanceados e da pequena freqüência dos mesmos, optou-se pela estimação dos dados perdidos pelo método padrão de mínimos quadrados para todos os dados disponíveis. Para as variáveis em que se estimaram dados perdidos seria indicado fazer a correção dos graus de liberdade do resíduo segundo Gomes (1981). Essa correção não foi efetuada devido ao número de graus de liberdade do resíduo ser bastante grande, o ajuste,neste caso, não provocaria alterações consideráveis nos resultados.

As análises de variância foram conduzidas utilizando-se o Procedimento GLM do SAS (Statitical Analysis System ), sendo que este procedimento oferece também as esperanças dos quadrados médios para as fontes de variação consideradas no modelo. 
Tabela 2. Análise de variância e esperanças dos quadrados médios para o modelo (1).

\begin{tabular}{|c|c|c|c|c|}
\hline $\begin{array}{l}\text { Fontes de } \\
\text { variação }\end{array}$ & GL & QM & $E(\mathrm{QM})$ & $\mathrm{F}$ \\
\hline Regiōes & 2 & Q1 & $\begin{array}{l}\sigma^{2} e+36 \quad \sigma^{2} p+ \\
Q(\text { Região) }\end{array}$ & \\
\hline Pop 's / Reg 1 & 12 & Q2 & $\sigma^{2} e+4 \sigma^{2} p 1$ & Q2/Q5 \\
\hline Pop 's / Reg 2 & $\overline{12}$ & $\overline{Q 3}$ & $\sigma^{2} e+4 \sigma^{2} p 2$ & Q3/Q5 \\
\hline Pop 's / Reg 3 & 12 & Q4 & $\sigma^{2} e+4 \sigma^{2} p 3$ & Q4/Q5 \\
\hline Resíduo & 114 & Q5 & $\sigma^{2} e$ & Q5 \\
\hline
\end{tabular}

Com base no modelo (1) serão realizados três tipos de testes de

hipoteses:

a - testa se há diferença entre as populações dentro de cada região. Teste da hipótese $H_{0}: \sigma_{P(j)}^{2}=0$ contra a hipótese altemativa $H a: \sigma_{P(j)}^{2} \neq 0$;

b - testa se há diferença entre as regiões com relação à magnitude das variâncias. Teste da hipótese $H o: \sigma_{P(j)}^{2}=\sigma_{P\left(j^{\prime}\right)}^{2}$ contra a hipótese alternativa $H a: \sigma_{P(j)}^{2}>$ $\sigma^{2} P\left(i^{\prime}\right)$. Onde $u=[S Q($ pop's(região $\left.=j)) / G L(j)\right] /\left[S Q\left(p o p ' s\left(\right.\right.\right.$ região $\left.\left.\left.=j^{\prime}\right)\right) / G L\left(j^{\prime}\right)\right]$ que tem distribuição F central com GL (j) graus de liberdade no numerador e GL (j') graus de liberdade no denominador, sob a hipótese de nulidade. Desde que a variável aleatória SQ (j) $=\left(S Q\right.$ (pop's $($ região $=j) /\left(\sigma^{2} e+4 \sigma^{2} P(j)\right)$ é $X^{2}$ com $G L(j)=$ (número de populações da região $j-1)$ e a variável aleatória $S Q\left(j^{\prime}\right)=\left(S Q\left(\right.\right.$ pop's (região $\left.=j^{\prime}\right) /\left(\sigma^{2} e+4 \sigma^{2} P(j)\right)$ é $X^{2} \operatorname{com} G L(j)=$ (número de populações da região j' - 1) sendo ambas as somas de quadrado independentes (GRAYBILL, 1961);

c - testa se as regiões diferem em média, para aquelas variáveis que não diferiram em variância. Teste da hipótese $H_{0}: R 1=R 2=R 3$, contra a hipótese alternativa Ha de que pelo menos um dos efeitos seja diferente, isto é, se há diferença entre os efeitos de regiões.

Para obter-se uma esperança de quadrados médios adequada ao teste do efeito de região, teste "c", que é uma combinação das esperanças de quadrado médio e que inclui todos os termos da esperança de quadrado médio do efeito de região excetuandose este efeito, foi feita uma combinação dos quadrados médios das outras fontes de variação do modelo, e uma aproximação de Sattertwaite foi empregada para determinar os graus de liberdade do numerador e denominador. 
Foram estimados ainda com base no modelo (1), os componentes de variância utilizando-se o método dos momentos.

Quando não foi possivel rejeitar-se $a H_{0}$ do teste descrito em " $b$ " assumiu-se que $\sigma_{p(j=1)}^{2}=\sigma_{p(j=2)}^{2}=\sigma_{p(j=3)}^{2}$ e utilizou-se o modelo a seguir :

$Y_{i j k}=m+b_{k}+R_{j}+P_{i(j)}+e_{i j k}$

onde: todos os efeitos são iguais aos descritos no modelo (1) com exceção de $P_{i(j)}$.

$P_{i}(j)=$ efeito genético das populações $i$, na região $j$. Sendo $P_{i}$ (j) uma variável aleatória com média 0 e variância $\sigma_{P(j)}^{2} ; i=1, \ldots 39$.

Neste modelo assume-se que a variável aleatória $\mathbf{P}_{\mathbf{i}}$ (j) tem variância comum em todas as regiőes.

$$
\begin{aligned}
& V r=a \text { diversidade entre regiōes, } \\
& V r=\left(\sum R^{2} j / r-1\right)
\end{aligned}
$$

- Tabela 3. Análise de variância e esperanças dos quadrados médios para o modelo (2).

\begin{tabular}{l|c|c|l|c}
\hline Fontes de variação & GL & QM & E (QM) & $F$ \\
\hline Regiões & 2 & $\mathrm{Q} 1$ & $\sigma^{2} e+4 \sigma^{2} p+52 \mathrm{Vr}$ & $\mathrm{Q} 1 / \mathrm{Q} 2$ \\
\hline Pop 's ( Reg's) & 36 & $\mathrm{Q} 2$ & $\sigma^{2} \mathrm{e}+4 \sigma^{2} \mathrm{p}$ & $\mathrm{Q} 2 / \mathrm{Q} 5$ \\
\hline Resíduo & 114 & $\mathrm{Q} 5$ & $\sigma^{2} \mathrm{e}$ & $\mathrm{Q} 5$ \\
\hline
\end{tabular}

Quando obteve-se significância para o efeito de região, foi realizado um teste de Tukey para comparar as médias de região duas a duas, utilizando-se como quadrado médio do erro aquele associado a populações dentro de regiões.

\subsubsection{Caracteres quantitativos - análise multivariada.}

Segundo REYMENT (1982), morfometria implica na descrição quantitativa da variação morfológica de organismos, plantas e animais. Morfometria multivariada, consiste na aplicação da teoria e prática da análise estatística multivariada para dois ou mais caracteres considerados simultaneamente.

Para comparar as populações das três regiões estudadas com base em todas as variáveis quantitativas avaliadas, foi usado o procedimento multivariado de análise canônica discriminante. 
Segundo KRISHNAIAH \& KANAL (1982), o principal procedimento estatístico multivariado para comparar e contrastar duas ou mais populações é o método das variáveis canônicas. $O$ interesse em fazer tais comparações é observado em estudos de variabilidade geográfica e ecológica, estudos taxonômicos e análise de mudanças fenotípicas através do tempo.

As variáveis canônicas são combinações lineares das variáveis quantitativas originais, que maximizam a variação entre grupos. Os coeficientes canônicos oferecem o contraste entre as médias, no presente caso de regiões, que são responsáveis pela maior percentagem da diferença entre as mesmas; de um modo semelhante àquele que os componentes principais realizam em relação à variação total de grupos.

Desse modo utilizaram-se as 17 variáveis quantitativas estudadas: comprimento do cotilédone, largura do cotilédone, comprimento do internó, distância para a primeira flor feminina, diâmetro do ramo principal, tamanho do pecíolo, número de ramos, tamanho de folha, peso de fruto, diâmetro de fruto, comprimento de fruto, espessura de casca, espessura de polpa, brix, número de sementes por fruto, peso de 50 sementes, tamanho de semente, e classificaram-se as populações por região, gerando duas classes.

A análise foi conduzida utilizando o Procedimento Candisc do SAS (Statistical Analysis System), para : 1 - confrontar o padrão de dispersão das populações frente ao critério de classificação por região; 2 - selecionar as variáveis com maior importância na diferenciação entre grupos. 


\section{RESULTADOS E DISCUSSÃO}

4.1. Variação qualitativa e quantitativa em 39 populações de melancia

\subsubsection{Variação para caracteres qualitativos}

As freqüências para cada variável estão representadas nas figuras de 05 a 12

Todos os caracteres estudados variaram nas três regiōes, muitas vezes apresentando diferentes proporçōes das categorias destas variáveis.

O caráter formato de frutos foi bastante variável entre regiōes. Os tipos cilindrico e longo somam cerca de $85 \%$ na região 1 , enquanto que nas outras duas regiōes estes tipos apresentam certa equitatividade em relaçào aos tipos redondo e oval somados.

\section{FORMATODE FRUTO}

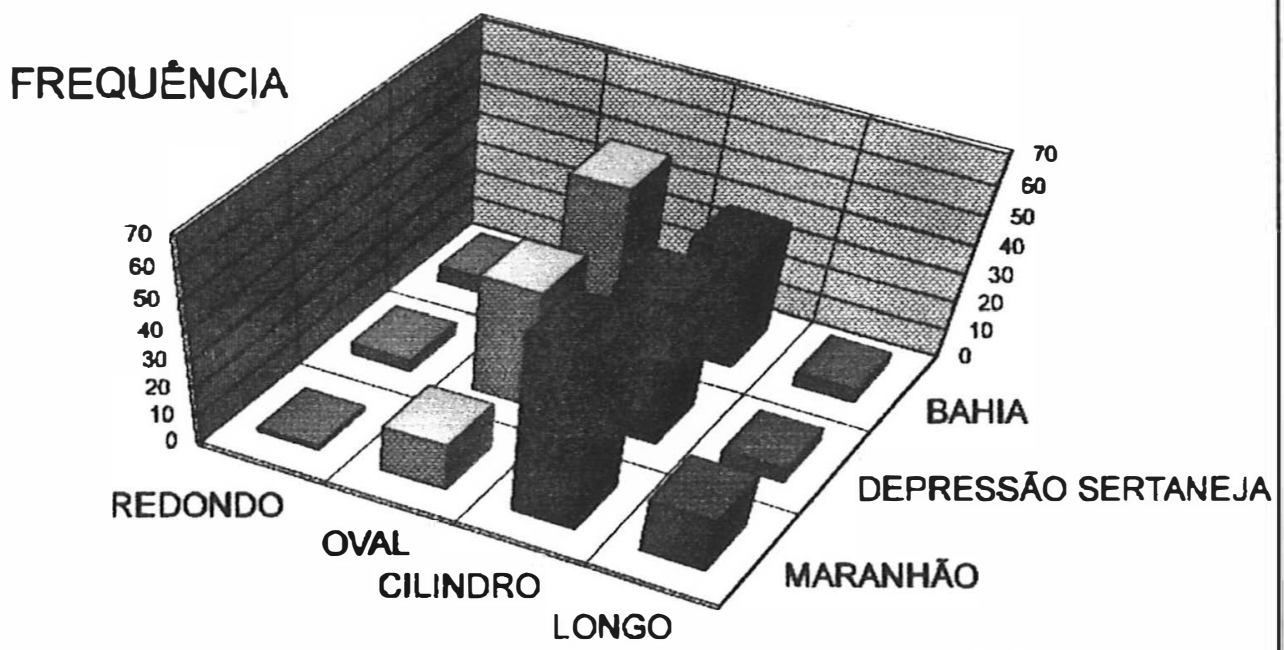

REGIÃO

Figura 05. Representação da frequência de cada categoria, por região, para formato de fruto, em C. lanatus. 


\section{COR EXTERNA PREDOMINANTE}

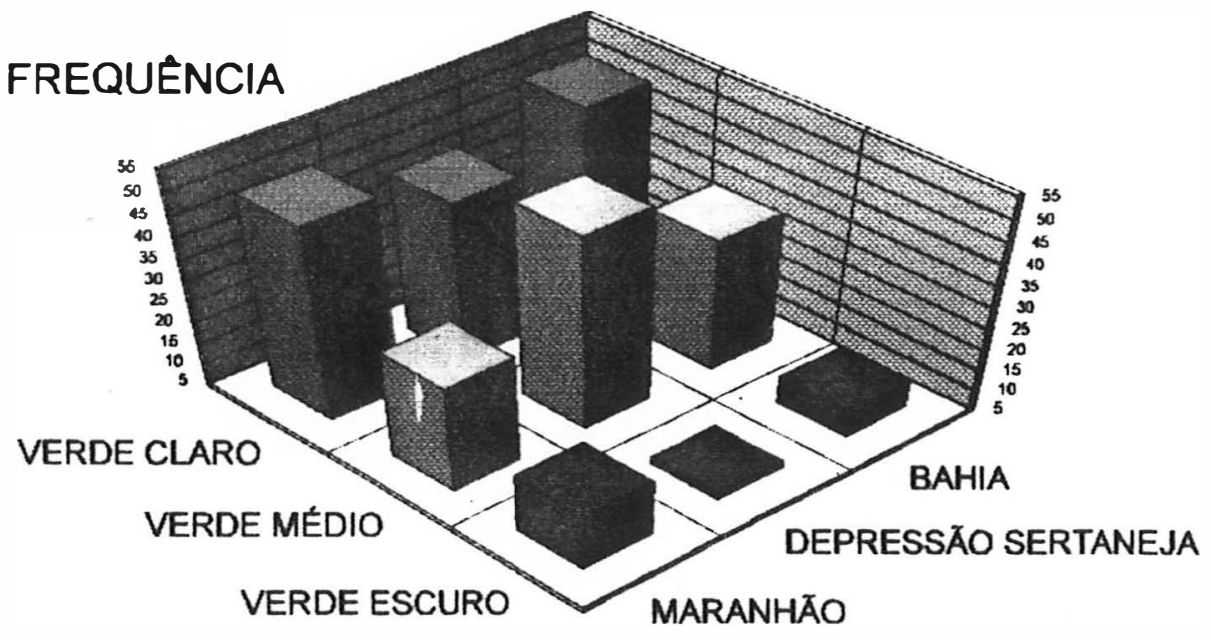

REGIĀO

Figura 06. Representação da frequência de cada categoria, por região, para a cor extema predominante, em C. lanatus.

\section{PADRÃO DE CASCA}

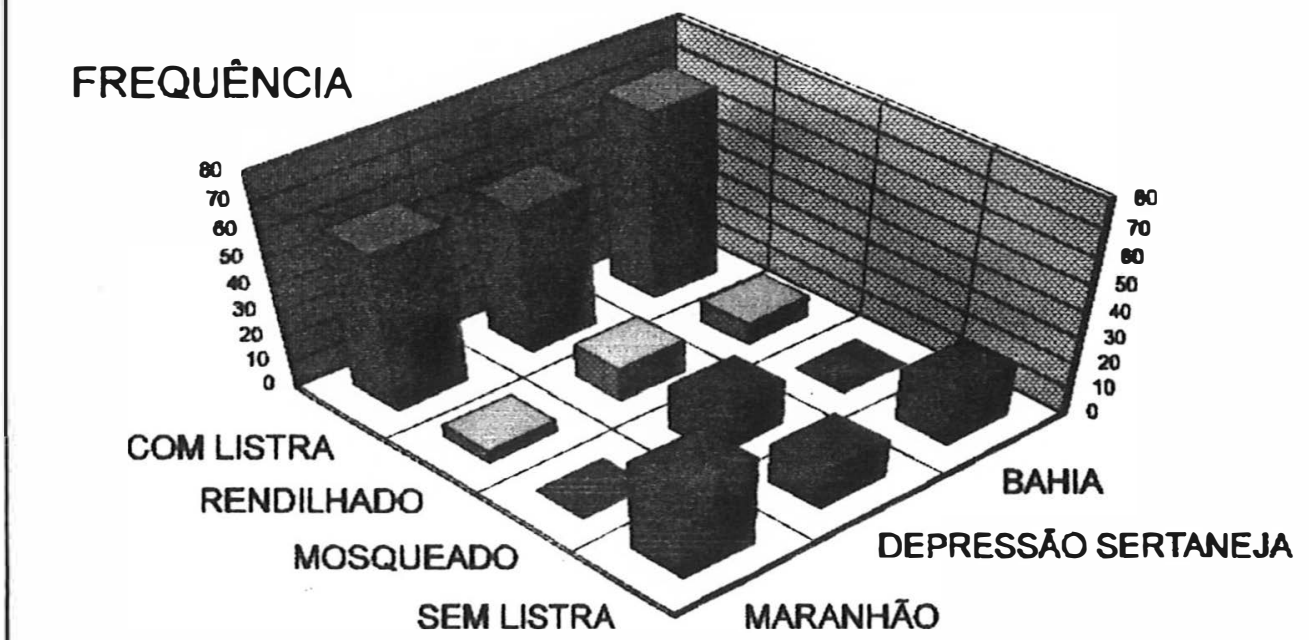

REGIĀO

Figura 07. Representação da frequência de cada categoria, por região, para padrão de casca, em C. lanatus. 


\section{COR DAS LISTRAS}

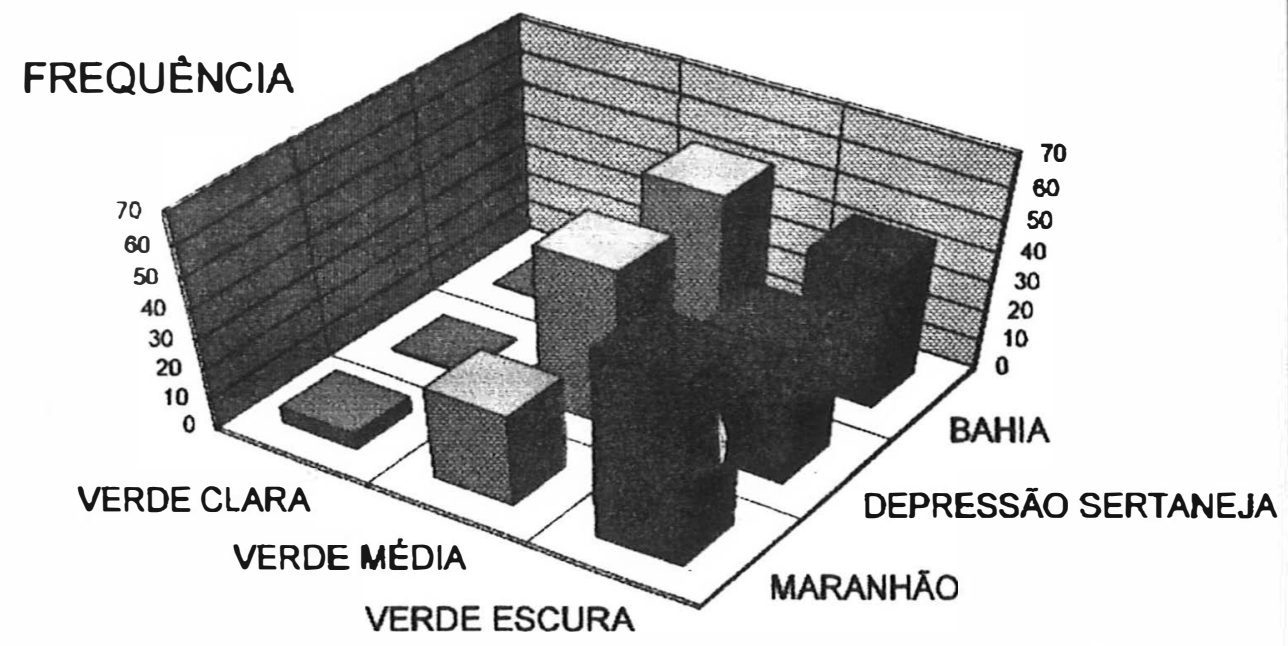

REGIÃO

Figura 08. Representação da frequência de cada categoria, por região, para cor das listras, em C. lanatus.

\section{ESPESSURA DAS LISTRAS}

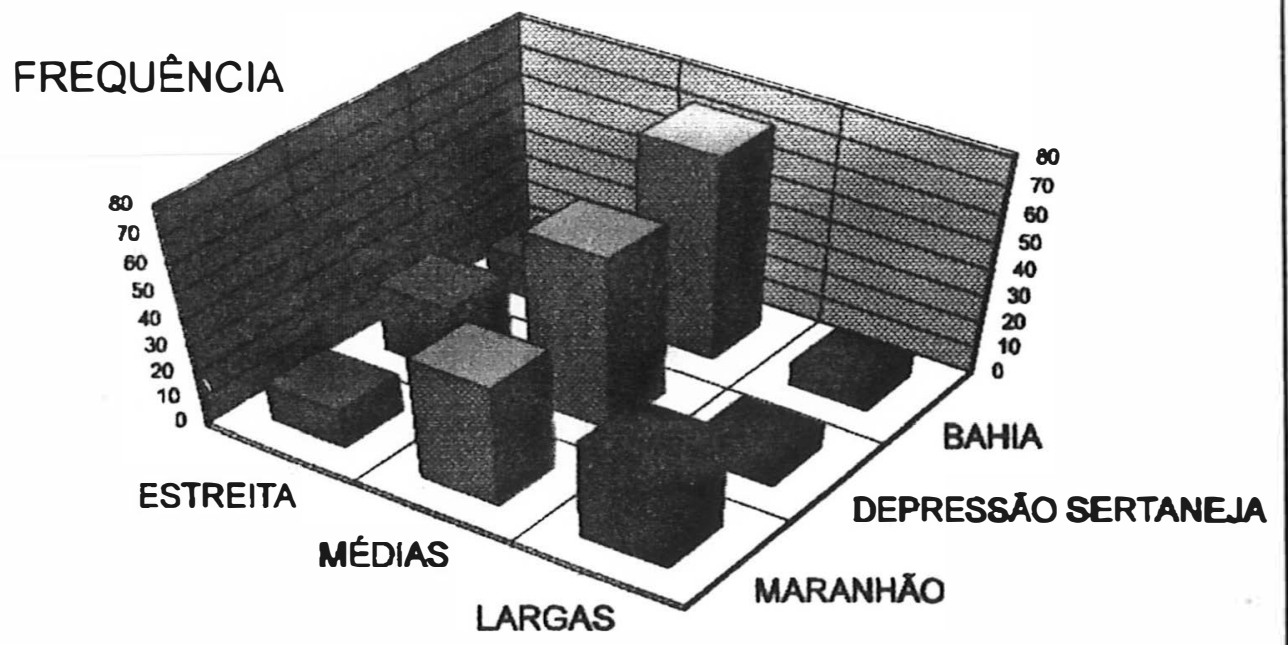

REGIĀO

Figura 09. Representação da frequência de cada categoria, por região, para espessura das listras em C. lanatus. 


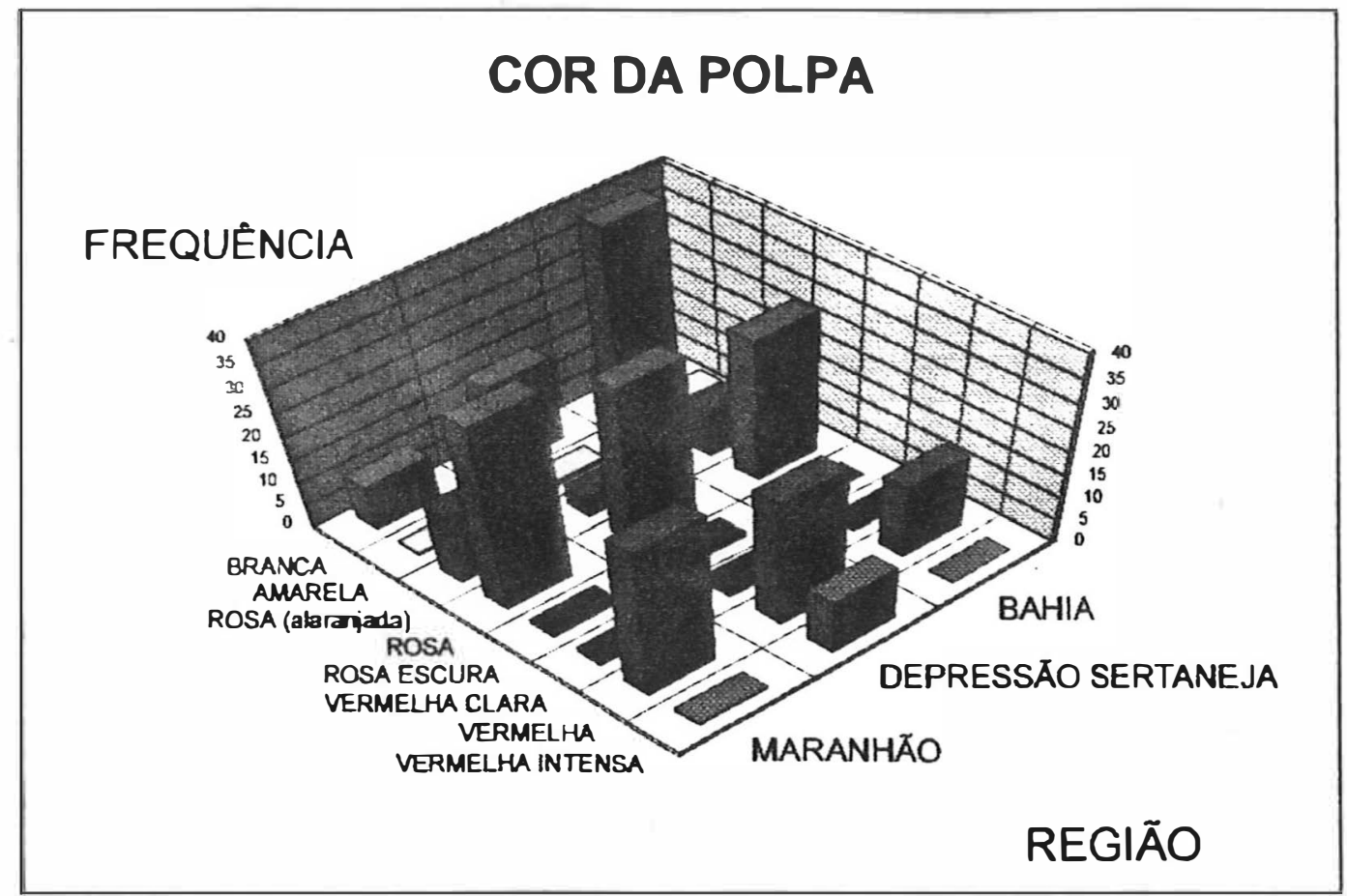

Figura 10. Representação da ocorrência de cada categoria, para cada região, para a variável: cor de polpa, em C. Lanatus.

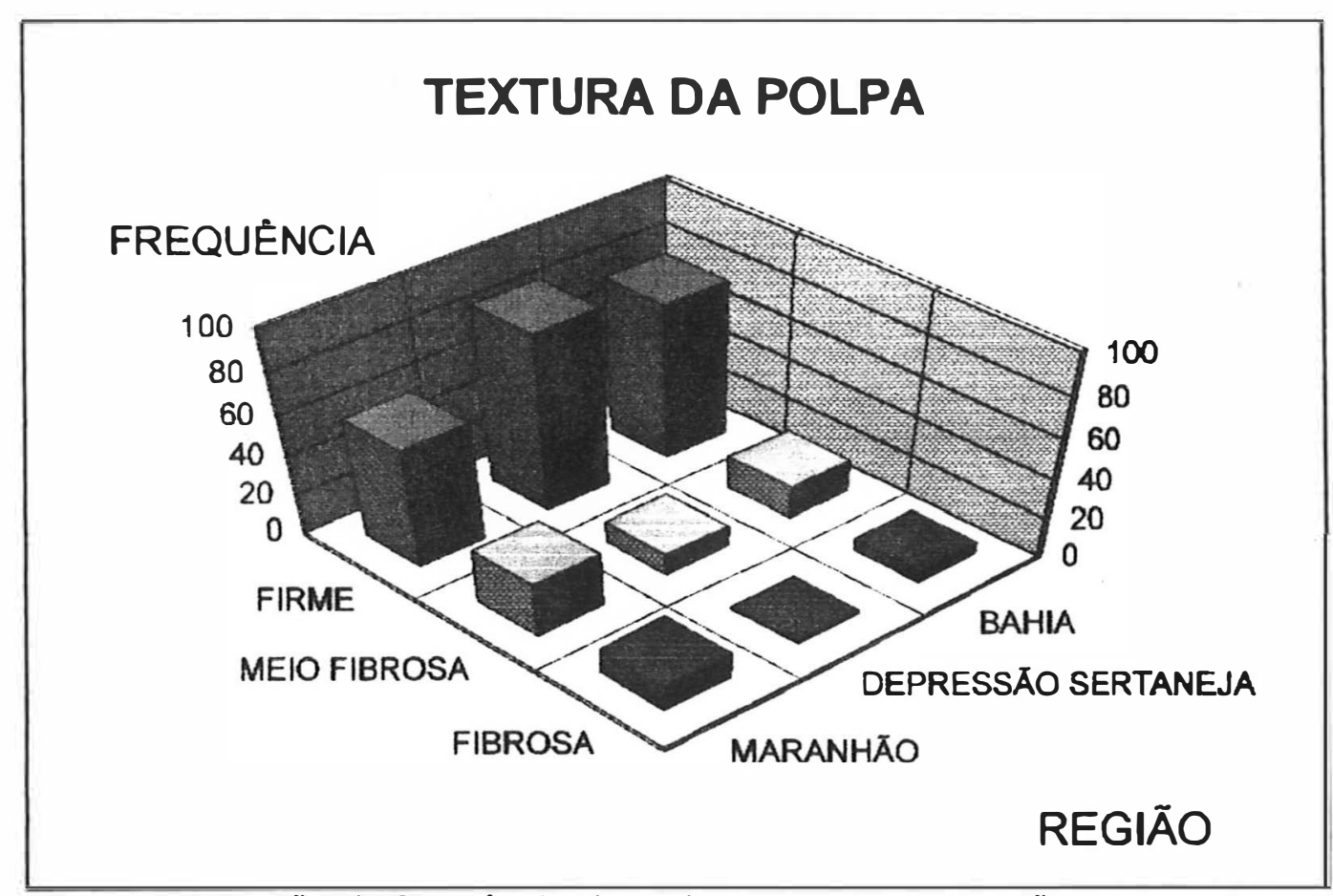

Figura 11. Representação da frequência de cada categoria, por região, para textura de polpa, em C. Ianatus. 


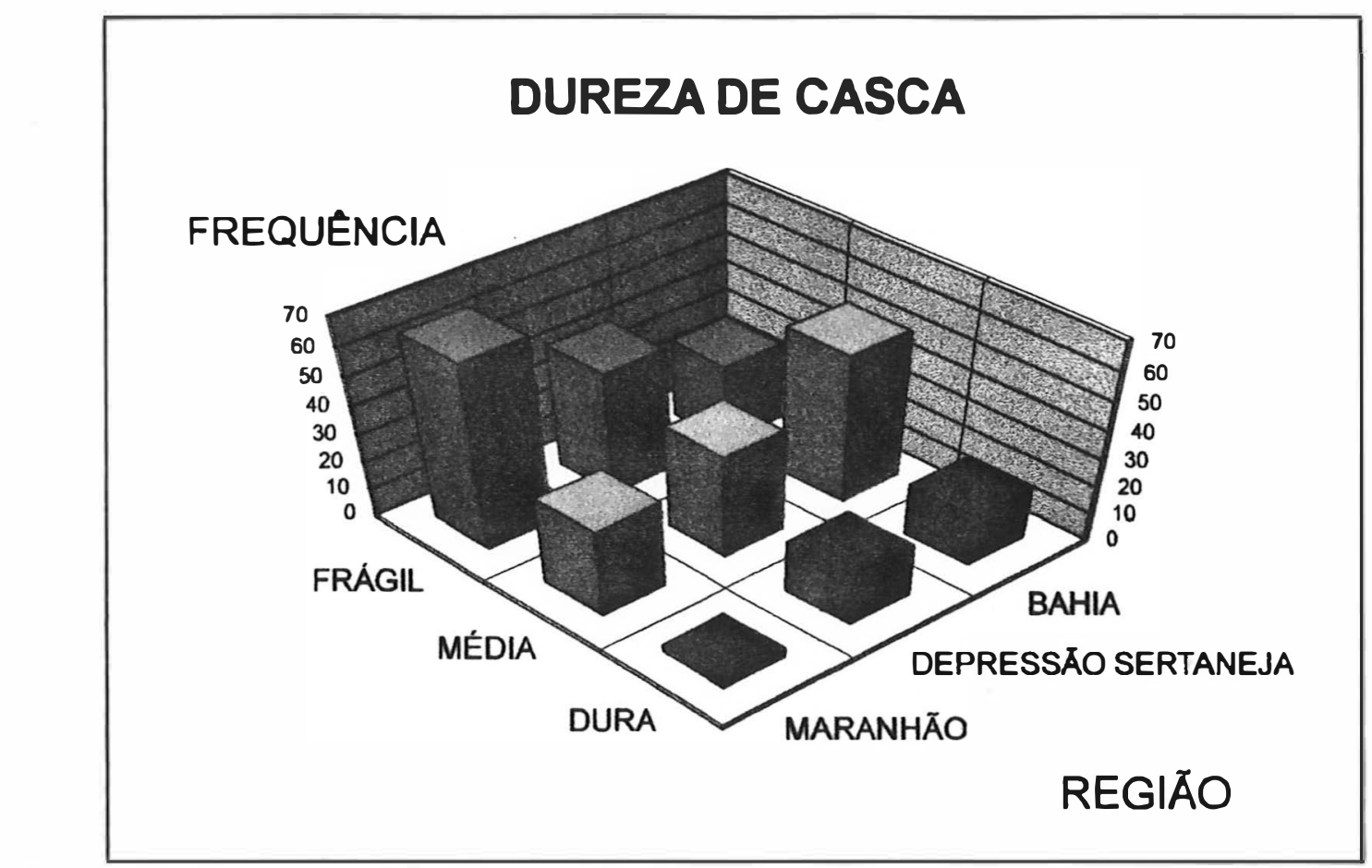

Figura 12. Representação da frequência de cada categoria, por região, para dureza de casca, em C. Lanatus.

A cor extema predominante foi a verde claro nas regiōes 1 - Maranhão e 3 - Bahia e verde médio na região 2 - Depressão Sertaneja, sendo o verde escuro menos frequente em todas as regiões.

Em relação ao padrão de casca, a listrada foi a predominante nas três regiōes mas o tipo mosqueado aparece de forma mais significativa apenas na região 2 Depressão Sertaneja, tendo sido mais comuns as listras verde médio e escuro. Listras verde claro foram encontradas em pequena frequência em todas as regiōes. As listras foram sempre de espessura predominante média sendo que as listras largas apareceram em maior proporção na região 1, e as estreitas foram mais comuns na região 2.

A cor da polpa apresenta-se dispersa nas diversas categorias em proporções similares nas três regiōes, sendo que o tipo branco foi mais expressivo na região 3 do que nas demais regiōes. Para o tipo vermelho a região 1 apresentou valor um pouco superior em relação as outras duas, enquanto o tipo vermelho intenso só é encontrado expressivamente na região 2.

A polpa dos frutos das três regiōes teve maior tendência a apresentar-se firme e, para a variável dureza de casca, predominaram os tipos frágil e médio, sendo que 
na região 1 o tipo frágil foi mais frequente e na região 3 o tipo médio. Na região 2 os três tipos estão bastante equilibrados.

No entanto, através das figuras, observa-se que uma região não é, consistentemente, mais variável que outra, isto é, a variação é elevada para algumas características, e reduzida para outras, dentro da mesma região.

Dentre as caracteristicas qualitativas estudadas podemos classifica-las de acordo com o seu grau de importância, desse modo, temos aqueles de importância primária padrão de casca, formato de fruto, textura de polpa, cor de polpa e dureza de casca e como de importância secundária a cor extema predominante, cor das listras e espessura das listras.

Considerando as variáveis de importância primária, as populações do Maranhão - região1, apresentaram pouca variabilidade para padrão de casca, formato de fruto, cor de polpa e dureza de casca. Estas mesmas variáveis têm grande variação na Depressão Sertaneja - região 2; na região 3 - Bahia, as variáveis padrão de casca, textura de polpa e cor de polpa apresentaram baixa variabilidade.

\subsubsection{Variação entre populações dentro de cada região}

Os resultados da análise da variância apresentados na Tabela 4 detectaram variabilidade intra-regional $\left(\sigma_{p(j)}^{2} \neq 0\right)$ para todas as variáveis estudadas, com exceção do diâmetro do ramo principal na região 3 , brix na região 1 e dias para 0 florescimento nas três regiões. Detectou-se assim na composição da variabilidade total observada nos dados experimentais, variação de natureza genética entre populações dentro de cada região para quase a totalidade das variáveis consideradas.

Os fatores que determinam a variabilidade intra-regional têm componentes, neste caso, que devem estar relacionados com a variabilidade do germoplasma introduzido em cada região, com o efeito fundador, com a ação antrópica uma vez que o homem promove a seleção de tipos especificos, e também com a biologia das populações.

A variabilidade do germoplasma introduzido em cada região, deve ter sido variável no tempo e no espaço. A ocupação das áreas, dentro de cada região, deu-se durante um longo periodo de tempo, e provavelmente, com materiais de origens diferentes. 
Tabela 4. Estimativas dos quadrado médios para: populações dentro da região - 1, QM (Pop's/Reg 1); populações dentro da regiâo - 2, QM (Pop's/Reg 2); populações dentro da região - 3, QM (Pop's/Reg 3). Resultados obtidos de médias de parcela.

\begin{tabular}{|c|c|c|c|}
\hline Caracteres & Pop's/Reg1 & Pop's/Reg2 & Pop's/Reg3 \\
\hline $\begin{array}{l}\text { Comprimento do } \\
\text { Cotilédone }\end{array}$ & $5,9 \times 10^{-1 / * *}$ & $6,5 \times 10^{-1 / * \star}$ & $4,2 \times 10^{-1} \star * t$ \\
\hline Largura do Cotilédone & $3,1 \times 10^{-1} \star \star \star$ & $\underset{\star \star}{1,9} \times 10^{-1}$ & 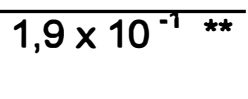 \\
\hline Tamanho de folha & $3,8^{\star \star}$ & $4,6^{\star \star}$ & $9,8^{\star \star}$ \\
\hline Tamanho do peciolo & $5,7^{\star \star}$ & $9,0^{* *}$ & $2,9^{\star \star}$ \\
\hline Comprimento do internó & $7,2 \times 10^{-1}$ & $1,6^{* *}$ & $1,0^{\star \star}$ \\
\hline Diâmetro do ramo principal & $5,0 \times 10^{-3 * *}$ & $1,1 \times 10^{-2} \star *$ & $\begin{array}{l}2,9 \times 10^{-3} \\
\text { ns }\end{array}$ \\
\hline Número de ramos & $1,0 \times 10^{-1} \star \star \star$ & $6,3 \times 10^{-2} * *$ & $5,6 \times 10^{-2}$ ** \\
\hline Dias para o florescimento & $\begin{array}{l}1,7 \times 10^{-1} \\
\text { ns }\end{array}$ & $\begin{array}{l}1,2 \times 10^{-1} \\
n s\end{array}$ & $\begin{array}{l}6,1 \times 10^{-4} \\
\text { ns }\end{array}$ \\
\hline $\begin{array}{c}\text { Distancia para } 1 \text { flor } \\
\text { feminina }\end{array}$ & $2,7 \times 10^{+2}$ & $6,4 \times 10^{+2 * *}$ & $\underset{* \star}{7,9} \times 10^{+2}$ \\
\hline Peso de fruto & $1,3^{* *}$ & $3,8^{\star \star}$ & $3,3^{\star \star}$ \\
\hline Comprimento fruto & $8,2 \times 10^{+1} \star \star \star$ & $\underbrace{9,3}_{* \star} \times 10^{+1}$ & $6,7 \times 10^{+1 * \star}$ \\
\hline Diâmetro de fruto & $5,5^{\star \star}$ & $6,6^{\star \star}$ & $6,0^{* *}$ \\
\hline Espessura de casca & $\begin{array}{l}7,2 \times 10^{-2} \\
\star \star\end{array}$ & $\prod_{\star \star}^{7,8 \times 10^{-2}}$ & $9,6 \times 10^{\prime<} \star \star$ \\
\hline Espessura de polpa & $5,5^{\star *}$ & $7,6^{\star \star}$ & $4,7^{* \star}$ \\
\hline Brix & $\begin{array}{l}7,0 \times 10^{-4} \\
\mathrm{~ns}\end{array}$ & $\prod_{* *}^{3,9} \times 10^{-4}$ & $2,6 \times 10^{-4} \star \star *$ \\
\hline Número de sementes & $\underset{\star \star}{5,9} \times 10^{+3}$ & ${ }_{* \star}^{3,1} \times 10^{+4}$ & $1,3 \times 10^{* 4} \star *$ \\
\hline Peso 50 sementes & $3,2^{\star \star}$ & $5,2 \times 10^{-1 \star \star}$ & $3,8 \times 10^{-1} \star *$ \\
\hline Tamanho de semente & 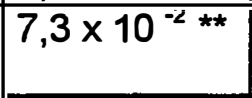 & $\underset{* \star}{2,1 \times 10^{-2}}$ & $1,1 \times 10^{-2} * *$ \\
\hline
\end{tabular}

$1 \mathrm{a}$ - Teste referente a hipótese $\sigma_{\mathrm{p}(\mathrm{)})}^{2}=0 ;{ }^{* *}$ significativo ao nível de $1 \%$; ns - não significativo

Além disso, o cultivo de cucurbitáceas é tradicionalmente realizado em áreas pequenas, com poucas plantas, favorecendo a ocorrência de endogamia (ALLARD,1971). Portanto, a ocorrência de deriva genética pode causar grande divergência entre as roças.

A seleção artificial promovida pelos agricultores é um outro fator de grande importância na variação observada entre populações dentro da mesma região. Isto 
está relacionado ao fato dos agricultores selecionarem a própria semente para o próximo plantio, e desta seleção obedecer a uma lógica especifica com objetivos particulares, como relata QUEIROZ et al. (1991), para as abóboras.

Os resultados obtidos mostram a importância da ação do agricultor na diferenciação dos materiais, como no caso do caráter cor de polpa, onde a maior frequência de vermelho intenso (11,85\%) (Figura 10), e textura de polpa firme (87,62 \%) (Figura 11) são observados na região 2 , nas roças onde o cultivo é realizado para fins prioritariamente comerciais.

Os componentes da história vital das populações associados aos sistemas de cultivo contribuíram para que essa variabilidade fosse mantida e talvez aumentada. Isso ocorreu devido à exposição de variedades diferentes ao intercruzamento e aos novos ambientes, à medida que estes foram sendo cultivados, e também por promover ou possibilitar a hibridação intra e interespecificas. Estes mecanismos devem ter aumentado a variabilidade dentro da roça, possibilitando a seleção de materiais específicos pelo agricultor e gerando, como consequência, divergência entre as roças.

A grande frequência da polpa branca nas três regiōes, caráter esse pertencente a C.colocynthis segundo MOHR (1986), mostra claramente a possibilidade de introgressão entre as espécies de Citrullus. Estes híbridos são mantidos pelos agricultores que os utilizam para alimentação animal em muitos casos.

\subsubsection{Variação entre regiões}

Para estudar a variabilidade existente entre as regiōes foram usadas duas estratégias, sendo a primeira delas verificar se as regiōes diferiam entre si em termos de variância (Tabela 5) e a segunda foi verificar, para as variáveis que apresentavam o mesmo padrão de variância, se estas diferiam em média (Tabela 6).

A comparação de médias, (Tabela 6), mostra que há diferenças entre as médias das regiões para seis das variáveis estudadas. Apenas para número de ramos não se detectou diferença significativa entre médias de região.

As variâncias das populações entre regiões diferem entre si, (Tabela 5) indicando que há diferenças com relação à magnitude desta variabilidade nas diferentes regiōes.

Os resultados mostram que para as variáveis comprimento do internó, distância da primeira flor feminina, diâmetro do ramo principal, tamanho do peciolo, número 
de ramos, tamanho de folha, peso de fruto, brix, número de sementes, peso de 50 sementes e tamanho de semente, existem diferentes niveis de variabilidade entre regiões.

Para as variáveis comprimento de cotilédone, largura de cotilédone, número de ramos, diâmetro de fruto, comprimento de fruto, espessura de casca e espessura de polpa, existe uma variabilidade comum entre regiões. Destas, comprimento de cotilédone, largura de cotilédone, diâmetro de fruto, comprimento de fruto, espessura de casca e espessura de polpa, diferem em média de uma região para outra.

Para número de ramos não se detectaram diferenças entre regiões. Esta variável embora apresente diferenças em variabilidade dentro de cada região, não apresenta diferença significativa entre as regiões, nem quanto a média de região. Para este caráter todas as populações estudadas compõem uma população maior com a mesma média e variância.

As Tabelas 5 e 6, indicam que há diferenças quanto à variância e médias entre as regiões estudadas para a maioria dos caracteres. Os resultados encontrados mostram padrões diferentes de variabilidade com forte relação geográfica concordando com HARLAN (1975), que chama atenção para o fato de que cada região geográfica e ecológica pode ter seu próprio conjunto de cultivares com características genéticas particulares.

Segundo os resultados apresentados na Tabela 5, dentre as regiões estudadas a região 2 é a mais variável. As diferenças das populações entre regiões e a maior variabilidade observada na região 2, devem ser resultantes do germoplasma introduzido em cada região, das diferentes características ecogeográficas, dos sistemas de cultivo e da migração humana, um dos mecanismos de dispersão de sementes.

O germoplasma fundador da variabilidade em cada região está relacionado à história de ocupação das regiões estudadas.Os aspectos históricos levantados sugerem que a região 1, Maranhão, foi colonizada a partir de Olinda, além de ser um porto que recebeu os negros bantos, o que indica uma diferenciação com relação as regiões 2 , Depressão Sertaneja e 3, Bahia, já que estas estão mais próximas de Salvador área de predominância dos escravos sudaneses. Isto se pensarmos em termos de superioridade numérica já que, segundo RODRIGUES (1982) e VERGER (1987), houve uma mescla de procedências considerável durante todo o período do tráfico de escravos. 
Tabela 5. Estimativas dos componentes de variância para: populações dentro da região 1 $\sigma^{2} p(j=1)$; populações dentro da região $2 \sigma^{2} p(j=2)$; populações dentro da região 3 $\sigma^{2} p(j=3)$.

\begin{tabular}{|c|c|c|c|c|}
\hline Caracteres & $\sigma_{p(j=1)}^{2}$ & $\sigma_{p(j=2)}^{2}$ & $\sigma_{p(j=3)}^{2}$ & $\begin{array}{c}\text { Comparação dos } \\
\text { componentes de } \\
\text { variância * }\end{array}$ \\
\hline Comprimento de Cotilédone & $1,2 \times 10^{-1}$ & $1,3 \times 10^{-1}$ & $7,8 \times 10^{-2}$ & ns \\
\hline Larqura de Cotilédone & $6,6 \times 10^{-2}$ & $3,6 \times 10^{-2}$ & $3,6 \times 10^{-2}$ & ns \\
\hline Tamanho de folha & $4,0 \times 10^{-1}$ & $5,9 \times 10^{-1}$ & 1,9 & R2>R1; R3>R1 \\
\hline Tamanho de pecíolo & $9,0 \times 10^{-1}$ & 1,7 & $2,1 \times 10^{-1}$ & R2>R3 \\
\hline Comprimento de interno & $7,5 \times 10^{-2}$ & $3,0 \times 10^{-1}$ & $1,4 \times 10^{-1}$ & $\mathrm{R} 2>\mathrm{R} 1$ \\
\hline Diâmetro do ramo principal & $3,3 \times 10^{-4}$ & $1,9 \times 10^{-3}$ & 0,0 & $\mathrm{R} 2>\mathrm{R} 1 ; \mathrm{R} 2>\mathrm{R} 3$ \\
\hline Número de ramos & $2,0 \times 10^{-2}$ & $1,0 \times 10^{-2}$ & $8,2 \times 10^{-1}$ & ns \\
\hline Dias para o florescimento & $7,0 \times 10^{-3}$ & $0,0^{-}$ & $0,0 \times 10^{-3}$ & R1>R3 \\
\hline Distancia para 1 flor feminina & $2,7 \times 10^{+1}$ & $1,2 \times 10^{+2}$ & $1,5 \times 10^{+2}$ & R2>R1; R3>R1 \\
\hline Peso de fruto & $2,0 \times 10^{-1}$ & $8,3 \times 10^{-1}$ & $7,2 \times 10^{-1}$ & R2>R1; R3>R1 \\
\hline Comprimento fruto & $1,7 \times 10^{+1}$ & $2,0 \times 10^{+1}$ & $1,4 \times 10^{+1}$ & ns \\
\hline Diâmetro de fruto & 1,0 & 1,3 & 1,2 & ns \\
\hline Espessura de casca & $7,8 \times 10^{-3}$ & $9,1 \times 10^{-3}$ & $1,3 \times 10^{-2}$ & ns \\
\hline Espessura de polpa & 1,0 & 1,5 & $8,8 \times 10^{-1}$ & ns \\
\hline Brix & $6,4 \times 10^{-5}$ & $8,8 \times 10^{-5}$ & $5,4 \times 10^{-5}$ & R2>R1; R3>R1 \\
\hline Número de sementes & $6,4 \times 10^{+2}$ & $6,9 \times 10^{+3}$ & $2,6 \times 10^{-3}$ & $R 2>R 1 ; R 2>R 3 ; R 3>R 1$ \\
\hline Peso 50 sementes & $7,6 \times 10^{-1}$ & $8,8 \times 10^{-2}$ & $5,3 \times 10^{-2}$ & R1>R2; R1>R3 \\
\hline Tamanho de semente & $1,7 \times 10^{-2}$ & $4,9 \times 10^{-3}$ & $2,3 \times 10^{-3}$ & R1>R2; R1>R3 \\
\hline
\end{tabular}

Rj> Rj' = variância de $\sigma_{P(j)}^{2}$ é maior que a de $\sigma_{P(j)}^{2}$ ao nível de $1 \%$. * Não foram descriminadas nesta tabela as relações entre regiões onde não se detectaram diferenças significativas ao nivel de $1 \%$.

Tabela 6. Médias por região para as variáveis com padrão semelhante de variabilidade.

\begin{tabular}{l|ll|ll|lll}
\hline Caracteres & \multicolumn{2}{|c|}{ Região 1 } & \multicolumn{2}{c|}{ Região 2 } & \multicolumn{3}{c}{ Região 3 } \\
\hline Comprimento de cotilédone & 3,6556 & $\mathrm{~B}^{12}$ & 4,1936 & $\mathrm{~A}$ & 3,9537 & $\mathrm{~A}$ & $\mathrm{~B}$ \\
\hline Largura de cotilédone & 2,6552 & $\mathrm{~B}$ & 2,5642 & $\mathrm{~A}$ & 2,5214 & $\mathrm{~A}$ \\
\hline Número de ramos & 12,3082 & $\mathrm{~A}$ & 2,3951 & $\mathrm{~A}$ & 2,4334 & $\mathrm{~A}$ \\
\hline Comprimento de fruto & $\mid 27,245$ & $\mathrm{~A}$ & 24,020 & $\mathrm{~A}$ & $\mathrm{~B}$ & 19,997 & $\mathrm{~B}$ \\
\hline Diâmetro do fruto & 14,4476 & $\mathrm{~B}$ & 15,7157 & $\mathrm{~A}$ & 14,2745 & $\mathrm{~B}$ \\
\hline Espessura de casca & 11,3860 & $\mathrm{~A}$ & 1,2676 & $\mathrm{~A}$ & $\mathrm{~B}$ & 1,2626 & $\mathrm{~B}$ \\
\hline Espessura de polpa & 11,5748 & $\mathrm{~B}$ & 12,9757 & $\mathrm{~B}$ & 11,6968 & $\mathrm{~A}$ \\
\hline
\end{tabular}

$1 a$ - As médias seguidas com a mesma letra não diferem significativamente pelo teste de Tukey $5 \%$.

As regiões estudadas estão bastante distanciadas entre si, como pode ser observado na Figura 4, e apresentam características ecogeográficas bastante distintas. 
A região 1 , compreende quatro municípios bastante próximos; a região 2 , corresponde a cinco municípios e abrange a maior área dentre as três regiões. A região 3 , mesmo compreendendo 11 municípios, abrange uma área geográfica bem mais reduzida que a região 2 assemelhando-se, neste aspecto, mais à região 1 .

A região 1 tem predominância de solos do tipo latossolo vermelho e latossolo amarelo. Na região 2 encontram-se solos do tipo areias quartzosas, regossolos, bruno não cálcico, latossolo vermelho e vertissolo e na região 3 tem-se solos do tipo cambisolo eutrófico e latossolo vermelho.

Com relação ao regime pluviométrico, as Figuras 13,14 e 15 , mostram que as regiões têm um padrão de distribuição pluviométrico semelhante no que tange aos meses de maior e menor precipitação, mas apresentam severas diferenças quando se observa a precipitação anual (Figura 16), e a regularidade das chuvas. A região 1 é, entre as três, a de maior umidade, apresentando a maior pluviosidade $(1.300$ a $1.600 \mathrm{~mm})$ e a menor irregularidade no regime pluviométrico; a região 2, é a mais seca (401 a $560 \mathrm{~mm}$ ) apresentando o regime pluviométrico mais errático, no tempo e no espaço e a região 3 apresenta pluviosidade ( 530 a $760 \mathrm{~mm}$ ) menor que a região 1 e maior que a região 2 , e um menor grau de imprevisibilidade (HEARGREAVES, 1973; PAZ, 1990).

As caracteristicas ambientais (pedológicas e pluviométricas) indicam que as populações das regiões 1 e 3 , experimentam, nessas regiões, pressões de seleção mais semelhantes, quando comparadas à região 2 que agrega um conjunto de ambientes mais diferenciados entre si.

$\mathrm{Na}$ região 2 é observada uma maior variabilidade de tipos de solos, contra dois tipos nas outras regiões. $O$ regime pluviométrico é caracterizado por secas ocasionais, pela irregularidade das chuvas, e pela grande diferença observada entre localidades. Parece acertado supor que a estas diferenças ambientais correspondam diferentes pressões seletivas, que possibilitariam maior variabilidade entre as populações.

Quanto ao sistema de cultivo, o que se observa é que, devido as regiọ̃es 1 e 3 serem áreas geográficas menores, há maior facilidade na permuta de materiais entre agricultores, do que na região 2 , ocasionando uma maior homogeneização da variabilidade dentro dessas regiões.

Favorecida provavelmente pelo tipo de regime pluviométrico e pelo sistema de cultivo, foi observada dormência nas populações um e seis da região 2. A dormência permite a formação de um banco de sementes no solo e, consequentemente, a 
formação de populações sub-espontâneas. A possibilidade de fluxo gênico e recombinação, entre essas populações deve atuar aumentando a variabilidade nesta região

Com relação à migração humana, as informações indicam que as regiões tiveram inicialmente um grande fluxo migratório no sentido sertão-litoral e litoralsertão, provocado pelo intenso comércio de gado vindo do sertão e outro gêneros e suprimentos provenientes do litoral. A este periodo se seguiu um, de menor movimentação humana, devido a diminuição da importância do comércio entre essas regiões. A região 2 , desde a sua colonização, que ocorreu no final do século XVI, quando foi visitado pela primeira vez pela bandeira de Belchior Dias Moréa (RIBEIRO 1968), teve um comportamento diferenciado devido à influência do rio São Francisco como principal via de ligação entre o litoral e o Centro sul, tendo portanto a possibilidade de sofrer um enriquecimento continuo de novos materiais com as migrações subsequentes.

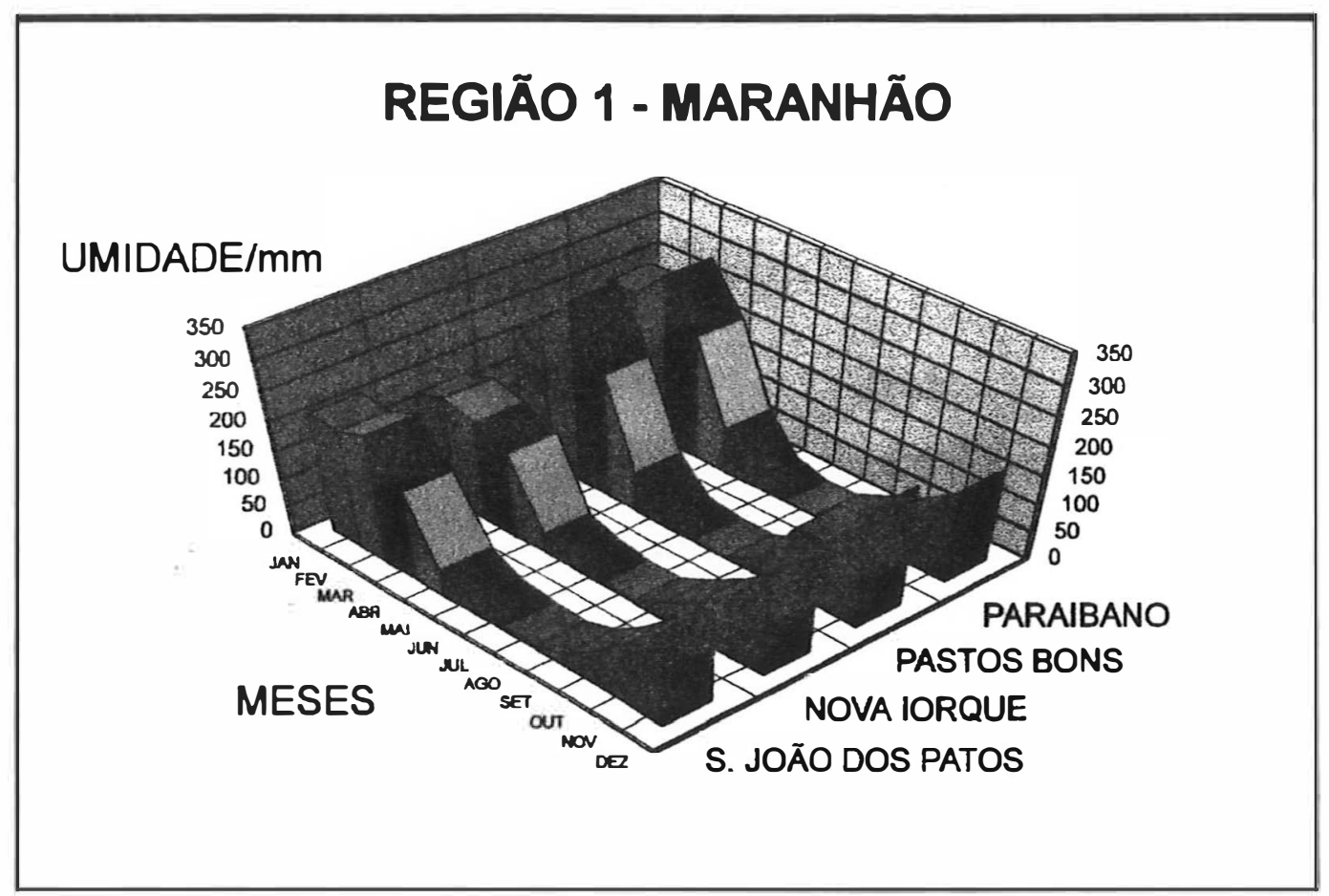

Figura 13. Distribuição pluviométrica mensal da região 1 - Maranhão. 


\section{REGIÃO 2 - DEPRESSÃO SERTANEJA}

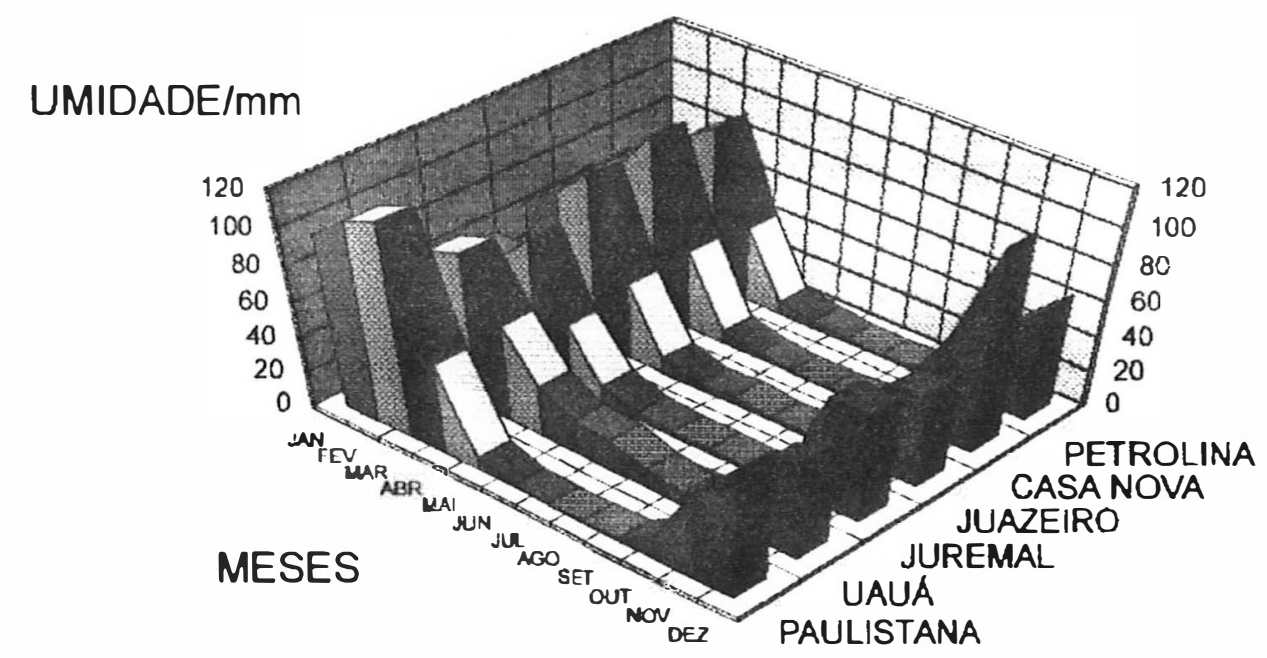

Figura 14. Distribuição pluviométrica mensal da região 2 - Depressão Sertaneja.

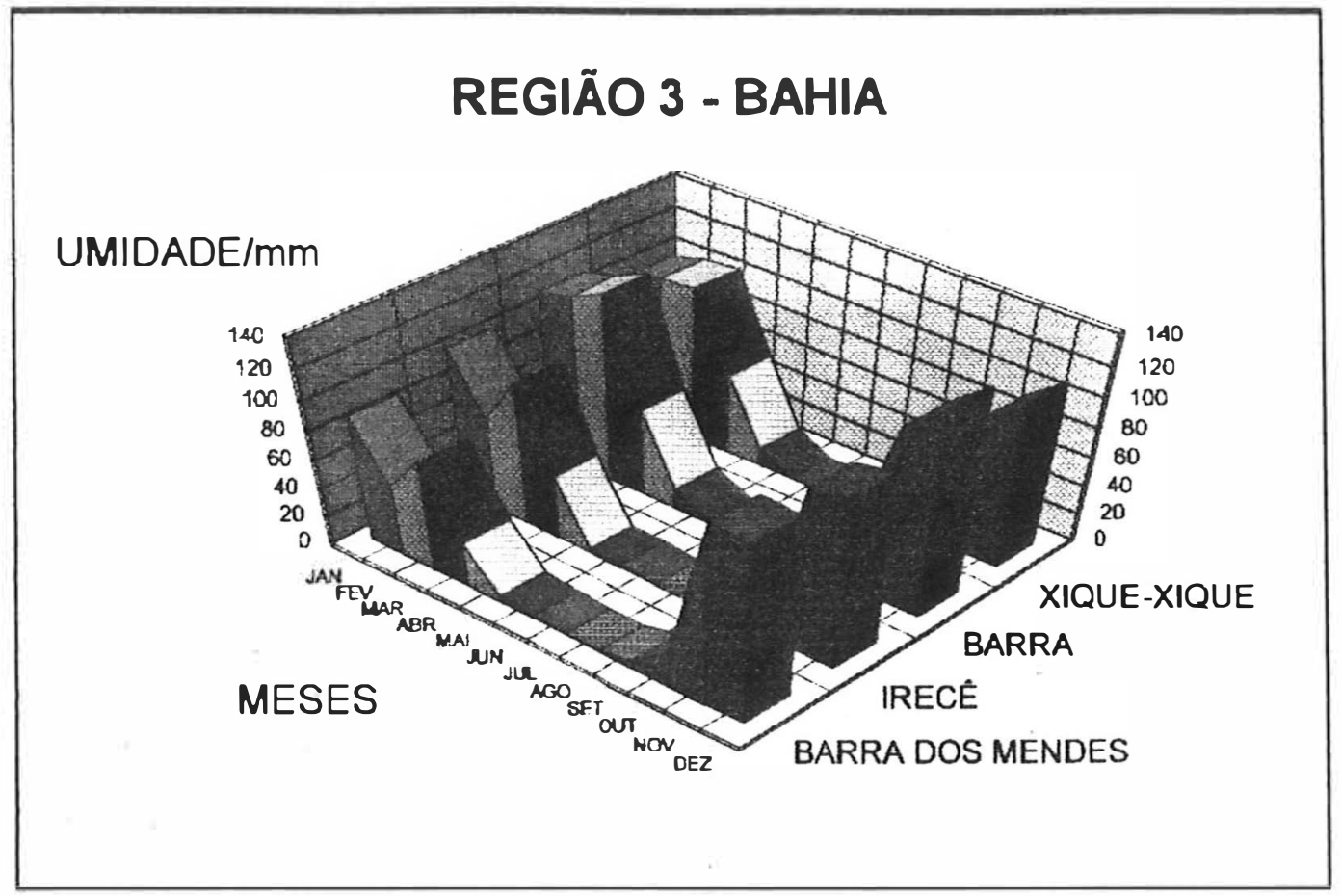

Figura 15. Distribuição pluviométrica mensal da região 3 - Bahia. 


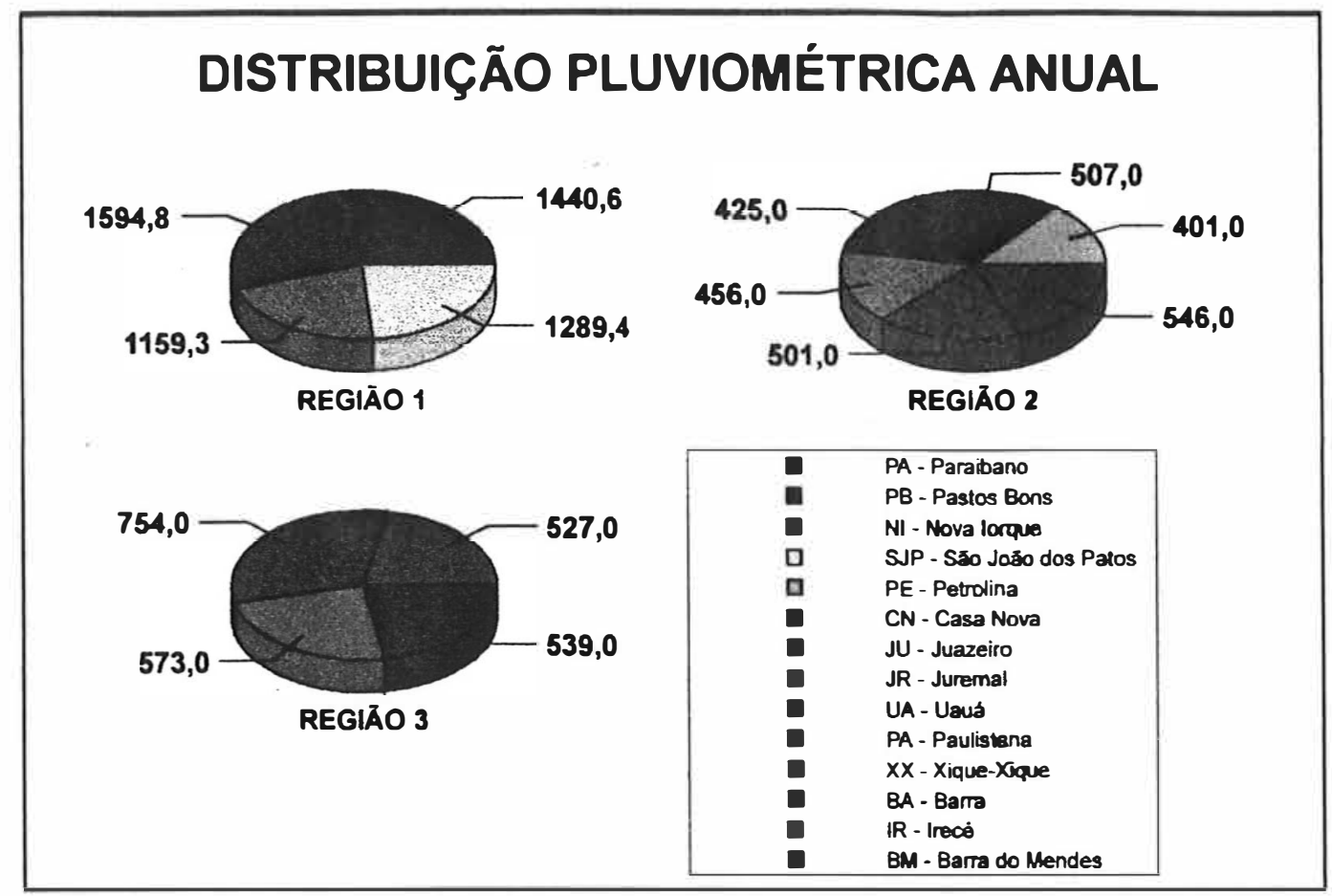

Figura 16. Distribuição pluviométrica anual nas localidades base das coletas.

Segundo LUETZELBURG, (1974), que esteve nessa região em 1910," Juazeiro tem importância como porto do rio São Francisco e também importância comercial, por ser centro de comércio com o sertão dos estados limitrophes.575 km ou 89 léguas distante da Capital do estado, tem o seu comércio um imenso raio de ação. Tem comércio ainda com Cabrobó, $200 \mathrm{~km}$ rio abaixo. Os seus artigos, em costas de burros,atingem os pontos mais longínquos do estado vizinho do Piauhy, como Oeiras, Jaicós, Pamagua, Colonia, no rio Pamaíba, que dista $800 \mathrm{~km}$ de Juazeiro. Seus artigos penetram através do rio Preto, até São Marcello, no rio Tocantins e rio Araguaya, perto de 2.000 km distante deste porto de real importância para o estado da Bahia. É pouco provável que outro porto no interior de qualquer estado da União,se possa medir com Juazeiro, quanto a importância comercial. Tropas carregadas atravessam durante meses as regiōes áridas e muitas vezes, só depois de anos, regressam com artigos que receberam em troca nos outros estados."

A migração contínua observada nesta região, e refletida na citação acima, teve certamente uma grande importância na variabilidade observada nas populações de melancia no Nordeste brasileiro, principalmente na região 2. 


\subsubsection{Análise multivariada.}

A Figura 17, resultante da análise multivariada das 17 variáveis estudadas, mostra o padrão de dispersão das 39 populações nas três regiões. Este gráfico indica claramente que o critério de classificação por região, diferencia os materiais e está de acordo com a variação morfométrica encontrada entre as populações.

A variação observada entre as regiões quando se fez a análise univariada das variáveis, permanece na análise multivariada como fator de grande importância no estabelecimento de grupos.

Os resultados mostram que as regiões são bem definidas e se relacionam com a história de ocupação das regiões estudadas, da ação do homem nestes locais, sua cultura, o modo como maneja os recursos naturais, e as distintas características agroecológicas e climáticas. Isto é refletido numa maior diversidade entre as regiões, mostrando que esta é uma classificação adequada para os materiais estudados. Mostra também que as populações estudadas compõem grupos diferentes em variabilidade.

\section{GRÁFICO DE DISPERSÃO 2}
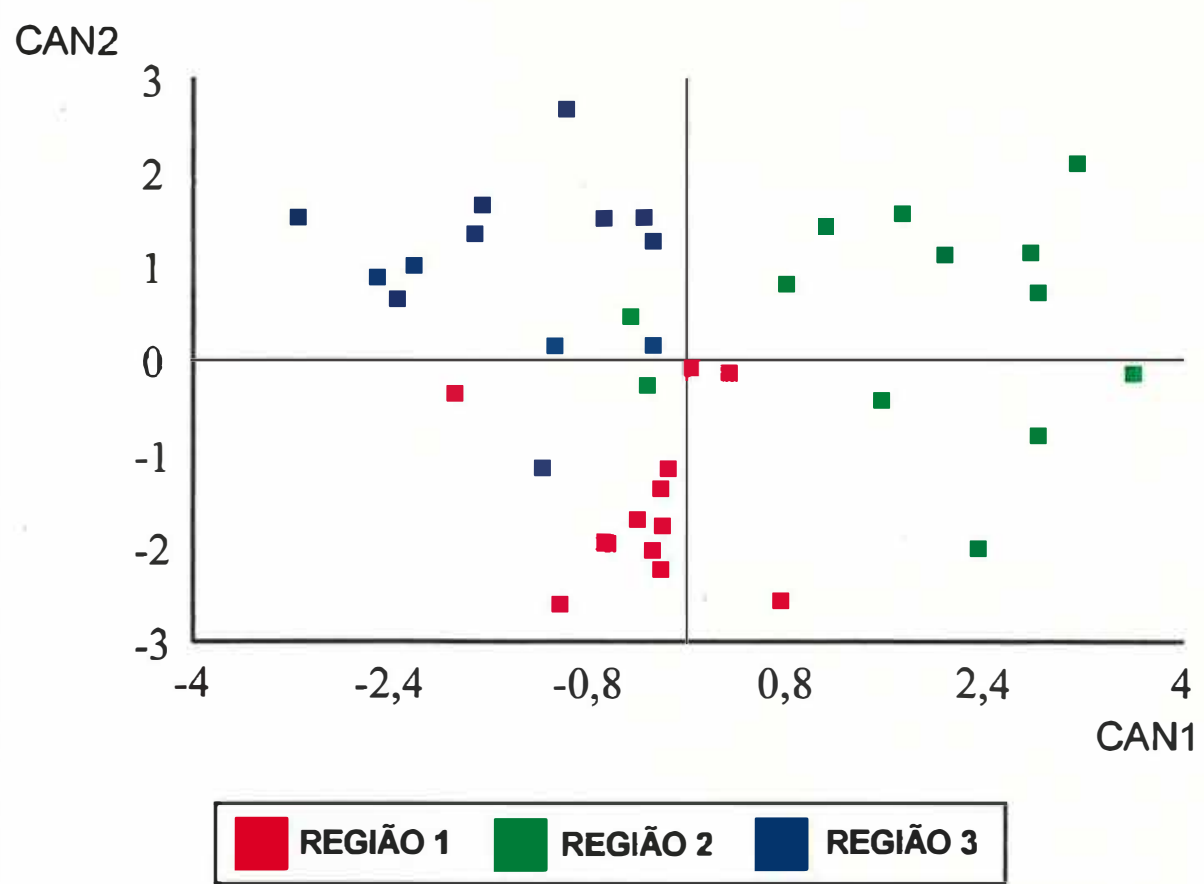

Figura 17. Padrão de dispersão de 39 populações de melancia (Citrullus lanatus), das regiões 1,2 e 3 utilizando-se 17 variáveis quantitativas. 
Para o estudo da importância de uma determinada variável dois critérios podem ser utilizados. O primeiro diz respeito à estabilidade dos coeficientes padronizados dentro de grupos, onde a perda da estabilidade sugere que a variável em questão pode ser redundante para a discriminação. O segundo critério está relacionado às variáveis com coeficientes canônicos padronizados pequenos o que indica que estas variáveis são redundantes e podem ser facilmente eliminadas (REYMENT , 1982).

Neste estudo utilizou-se o segundo procedimento como base para eliminação de variáveis.

O coeficiente de correlação canônico quando se estudaram as 17 variáveis foi de $r=0,8718$ o que significa que 0,76 da variação na primeira variável canônica é explicada pelas diferenças entre as regiōes.

Quando se utilizou a magnitude dos coeficientes canônicos pela variação dentro de grupos, para indicar a retirada de variáveis selecionando aquelas com valores acima de |0,70| em pelo menos um dos coeficientes canônicos CAN 1 e CAN 2 ( Tabela 7), obteve-se um grupo de nove variáveis assinaladas na tabela abaixo.

Tabela 7. Magnitude dos coeficientes canônicos pela variação dentro de grupos, para as variáveis estudadas.

\begin{tabular}{c|c|c}
\hline Caracteres & CAN 1 & CAN 2 \\
\hline Comprimento de cotiledone $^{*}$ & 0,75 & 0,57 \\
\hline Larqura de cotilédone & $-0,45$ & 0,59 \\
\hline Tamanho de folha & 0,26 & $-0,10$ \\
\hline Tamanho de peciolo & 0,46 & $-0,40$ \\
\hline Comprimento do interno & $-0,62$ & 0,20 \\
\hline Diâmetro do ramo principal & 0,24 & 0,76 \\
\hline Número de ramos & 0,29 & 0,16 \\
\hline Dist. para 1 flor feminina & 0,63 & $-0,11$ \\
\hline Peso de fruto * & 0,11 & $-1,76$ \\
\hline Comprimento de fruto $^{*}$ & $-0,84$ & 0,85 \\
\hline Diâmetro de fruto & 0,71 & 0,31 \\
\hline Espessura de casca & $-0,88$ & 0,49 \\
\hline Espessura de polpa ${ }^{*}$ & $-0,74$ & 1,44 \\
\hline Brix & 0,77 & $-0,14$ \\
\hline Número de sementes & $-0,11$ & 0,02 \\
\hline Peso de 50 sementes ${ }^{*}$ & 1,01 & $-2,27$ \\
\hline Tamanho de sementes ${ }^{*}$ & $-1,12$ & 2,06 \\
\hline
\end{tabular}


Analisando-se as variáveis: comprimento de cotilédone, peso de fruto, diâmetro de fruto, comprimento de fruto, espessura de polpa, brix, peso de 50 sementes, tamanho de semente e diâmetro de ramo principal, obteve-se como valor do primeiro coeficiente de correlação $r=0,8186$, que explicou 0,67 da variação entre regiões.

\section{GRÁFICO DE DISPERSÃO 1}

CAN2

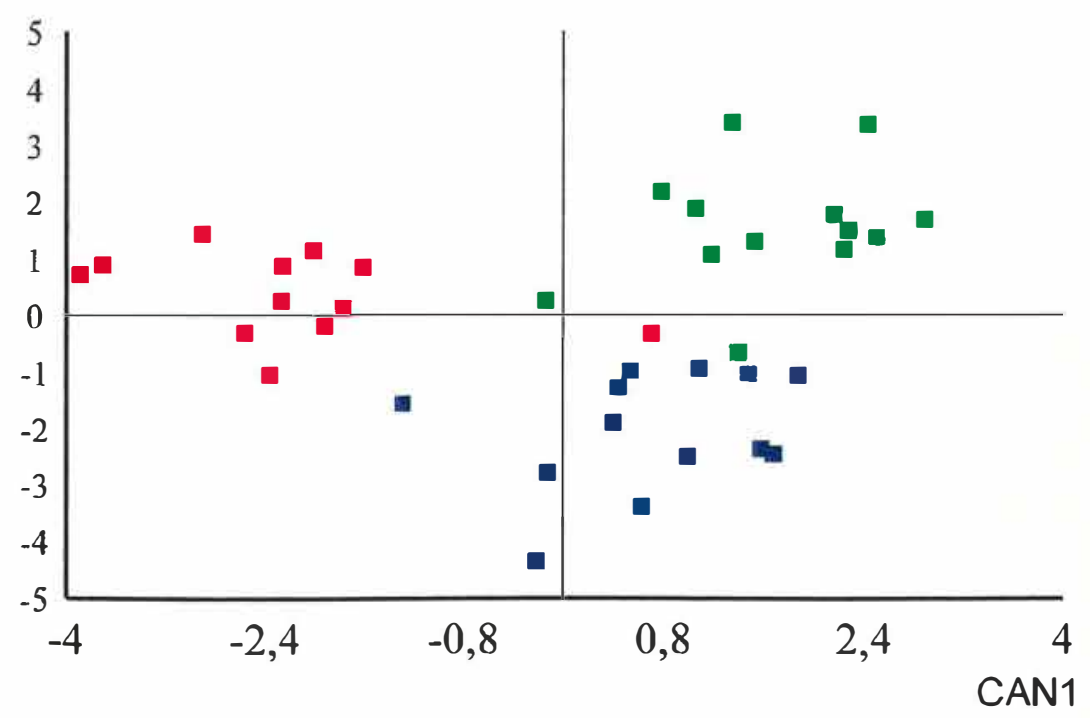

REGIÃO 1

REGIÃO 2

REGIÃO 3

Figura 18. Padrão de dispersão de 39 populações de melancia (Citrullus lanatus), das regiões 1, 2 e 3; utilizando-se 9 variáveis quantitativas.

A combinação linear (coeficientes canônicos) que gera a primeira variável canônica é estabelecida de modo a maximizar a variação entre regiões em relação a variação dentro de regiões.

Desse modo, o grupo de nove variáveis pode ser utilizado em estudos de variabilidade. Estas explicam $67 \%$ da variação contra $76 \%$ das 17 variáveis, com o descarte de nove variáveis. Além do que a utilização de nove ao invés de 17 variáveis torna o estudo mais viável e com um grau de precisão bastante razoável, como pode ser 
observado pelos coeficientes de correlação ( $r=0,8186$ e $r=0,8718)$, e distribuição espacial das populações nas Figuras 17 e 18.

Com base nos resultados da seleção de descritores, na variação observada neste estudo e nas avaliações observadas na literatura (LALTA PRASAD et al. , 1988; WHANG \& ZHANG,1988), sugere-se para a caracterização de germoplasma e divergência entre grupos, a substituição da lista de 26 descritores utilizadas neste estudo pela lista de 21 descritores abaixo.

1 - comprimento do cotilédone, de um um cotilédone por planta, nove dias após a germinação.

2 - diâmetro do ramo principal, obtido com paquímetro na base da planta, 70 dias após o plantio.

3 - vigor

1 - fraco

3 - regular

5 - bom

7 - excessivo

4 - início do florescimento - número de dias entre a semeadura até que um mínimo de $50 \%$ das plantas da parcela apresentem flores femininas.

5 - peso de fruto, expresso em $\mathrm{g}$.

6 - formato do fruto .

1 - redondo

3 - oval

5 - cilíndrico

7 - longo

7 - cor extema predominante.

1 - verde claro

3 - verde médio

5 - verde escuro

7 - amarelo

8 - padrão de casca.

1 - com listras

3 - rendilhado 


$$
\begin{aligned}
& 5 \text { - mosqueado } \\
& 7 \text { - sem listras }
\end{aligned}
$$

9 - comprimento do fruto, expresso em $\mathrm{cm}$.

10 - diâmetro do fruto, expresso em $\mathrm{cm}$.

11 - espessura de casca, expresso em cm.

12 - espessura de polpa, expresso em cm.

13 - cor da polpa.

1 - branco

2 - amarelo

3 - rosa alaranjado

4 - rosa

5 - rosa escuro

6 - vermelho claro

7 - vermelho

8 - vermelho intenso

14 - Brix - obtido com refratômetro de bolso.

15 - número de sementes por fruto.

16 - peso de 50 sementes, expresso em g.

17 - tamanho de sementes, média de três sementes por fruto, expresso em $\mathrm{mm}$.

18 - cor de sementes.

19 - número de frutos por planta.

20 - peso médio de frutos, expresso em $\mathrm{g}$.

21- comprimento do ramo principal, obtido 70 dias após o plantio, expresso em $\mathrm{cm}$. 


\subsection{A Dinâmica evolutiva da melancia no Nordeste do Brasil}

Segundo STEBBINS (1970), a teoria sintética da evolução reconhece três tipos básicos de processos geradores e amplificadores da variabilidade genética: mutação gênica, variações estruturais e numéricas dos cromossomos, e recombinação genética, além de outros três processos secundários quais sejam: migração, hibridação entre raças ou espécies e deriva genética, que ocorrendo ao nivel de populações são responsáveis pela variabilidade sobre a qual a seleção natural age.

A melancia, como já mencionado anteriormente, tem como centro de origem a África. Considerando-se o período de tráfico de escravos para o Brasil, cerca de 300 anos, o número e a procedência dos mesmos, pode-se esperar que tenha ocorrido introdução recorrente de variabilidade de melancia do continente africano, no Brasil.

Os relatos de VERGER (1987) e de SALDANHA (1989), mostram que

- houve uma certa predominância de escravos do grupo banto no norte do Maranhão e em Pemambuco e de sudaneses em Salvador e Recôncavo baiano (Figuras 19 e 20). RODRIGUES (1982), por outro lado, chama atenção para o fato de que mesmo com certa predominância de determinado grupo étnico em áreas específicas, houve a introdução de um número expressivo de indivíduos de diferentes nações africanas, nas mesmas regiões. Ainda hoje pode-se observar a preservação da cultura de nações diferentes em Salvador$\mathrm{BA}$, onde há casas de cultura Ketu (terreiro do Gantois e terreiro Axe Apo Afonjá) e Banto (terreiro Bate Folha). Dai concluir-se que, variedades locais de diversas origens, possivelmente chegaram às regiões de maior importância no tráfico de escravos, e foram ai cultivadas inicialmente.

A princípio as grandes concentrações humanas no litoral canavieiro, Salvador e Olinda (Figura 20), foram os primeiros novos hábitats para os africanos e para as melancias. As diferentes procedências dos africanos possibilitaram a atuação de dois processos evolutivos amplificadores de variabilidade: a hibridação intraespecifica e interespecífica, e a recombinação, fazendo com que variedades e mesmo espécies, que na África eram nativas ou cultivadas em regiōes isoladas entrassem em contato e se intercruzassem. 


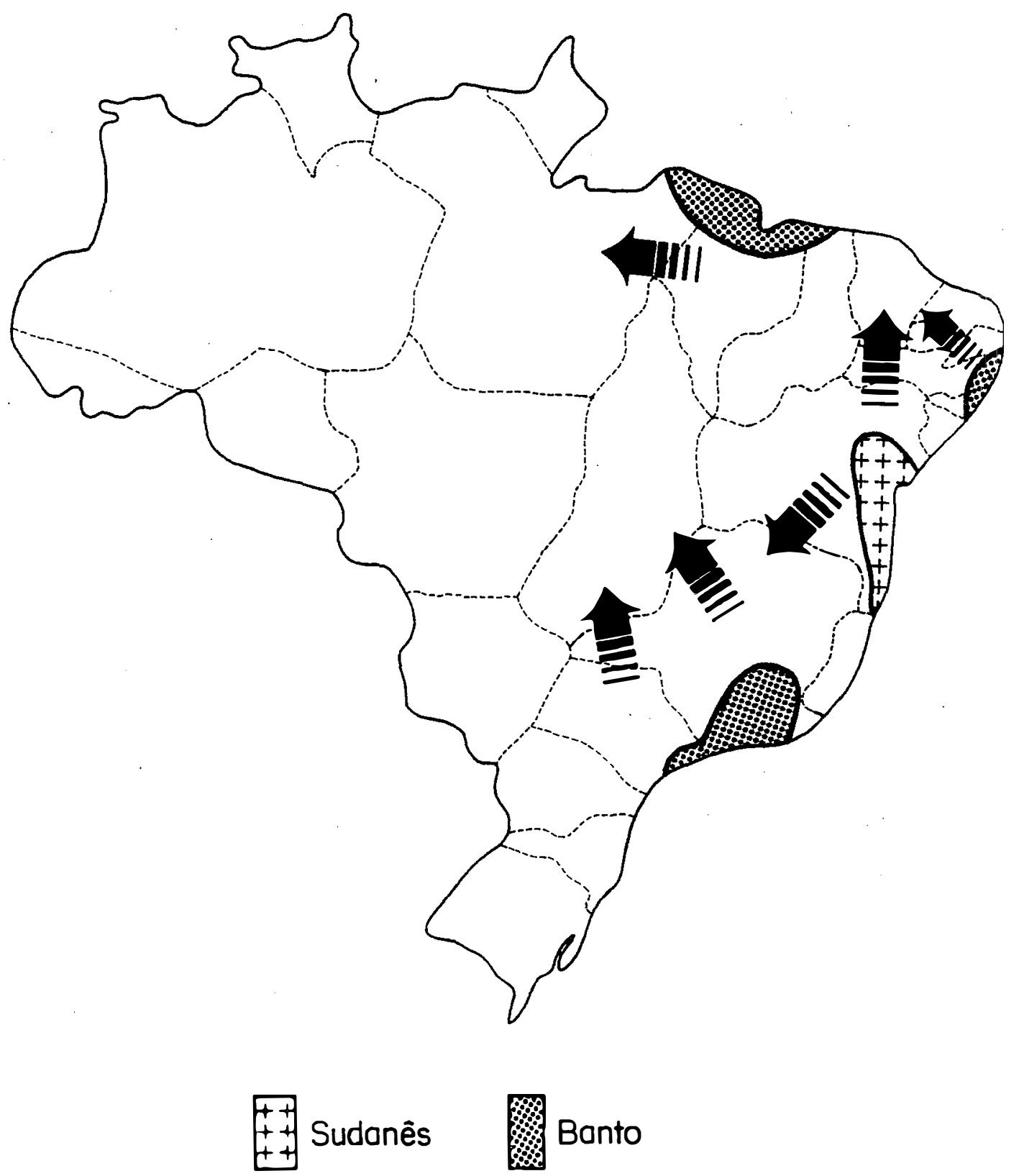

Figura 19. Regiões do Brasil que originalmente receberam escravos. As setas indicam as migrações posteriores; adaptada de Ciência Hoje, Vol. 9, 1989. 
As variedades que sofreram hibridação, recombinação e seleção natural no litoral canavieiro com a conquista e povoamento do Norte e Oeste, "os currais", devem ter sido dispersas pelos vaqueiros e bandeirantes, passando então a ser cultivadas em pequenas áreas para abastecer as populações locais. Nesta movimentação, o caminhar com a colonização foi expondo os materiais a novos ambientes, favorecendo assim a ação da seleção natural. As populações passaram a experimentar diferentes pressões de seleção e possivelmente, em alguns casos, o efeito da deriva genética, devido ao pequeno tamanho das roças, típico de cucurbitáceas.

A marcha da colonização (Figura 20), muito provavelmente, expôs as variedades de melancia ao cultivo por ocupantes de diferentes origens, índios e colonizadores portugueses e holandeses. Desse modo se deu a ampla distribuição que caracteriza a ocupação do espaço rural como é observado hoje - o estabelecimento das "roças". O encontro das variedades de melancia com culturas diferentes deve ter se refletido no aumento da diversidade entre propriedades, como resultado de pressões seletivas ambientais diferentes, e a seleção artificial, que mesmo sem grande rigor deve ser considerada pelas diferenças de interesse dos diferentes agricultores.

A migração é um processo acessório que deve ter contribuído para o aumento da variabilidade nas populações já cultivadas nos sertões, devido à ligação entre o sertão e o litoral, ter sido de grande importância durante um bom tempo, e esta ligação agir introduzindo novas combinações gênicas nos cultivos dos currais.

Hoje, no Nordeste, em áreas de cultivo tradicional como as estudadas neste trabalho, as roças se caracterizam pelo cultivo de sequeiro, realizado em pequenas unidades produtoras, extremamente numerosas, que desempenham o importante papel de abastecer sua força de trabalho e de colocar o excedente produzido no mercado local e regional. Estas unidades com sua longa tradição agrícola vêm permitindo, por processos empíricos, acumulação de preciosa experiência, adaptada concretamente ao meio físico, econômico e social (SOUZA, 1979).

O cultivo nas pequenas propriedades é caracterizado pelo consórcio de diversas culturas, variando o número e o tipo das mesmas a depender da região. No caso específico da melancia, além do consórcio com outras culturas, há o convívio de plantas semeadas pelos agricultores e sementes germinadas do banco de sementes do solo (Figura 21). 


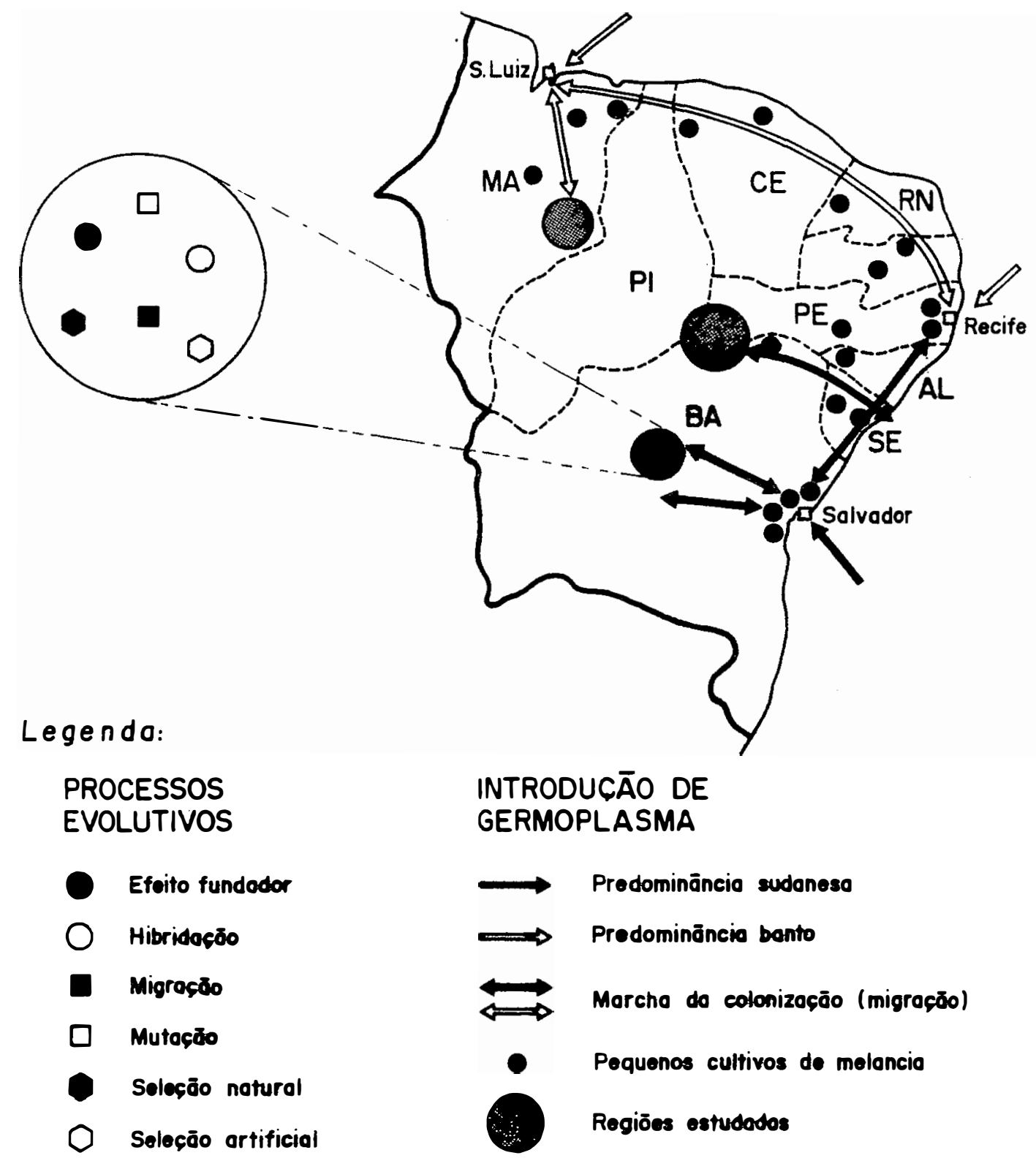

Figura 20. Introduçāo das variedades, a marcha de colonizaçāo e os processos evolutivos da melancia no Nordeste do Brasil. 
O banco de sementes se constitui de sementes dormentes, remanescentes de cultivos anteriores e, em alguns casos, sementes de populações conhecidas vulgarmente por melancia-de-cavalo ou melancia-de-porco.

O banco de sementes é resultado da ação conjunta de fatores genéticos (genes de dormência e explosão dos frutos) e ecológicos (sistemas de cultivo e dispersão pelo lobo guará) (Figura 22).

Como fatores genéticos tem-se a ocorrência de dispersão de sementes pela explosão dos frutos e exposição das sementes, caráter este controlado geneticamente, cujo símbolo é e ou $\boldsymbol{t}$ (ROBINSON, 1976), e a dormência de sementes (Figuras 24 e 25), fator identificado como de grande importância para a persistência e regeneração em condições de adversidade climática , e que permite a formação do banco de sementes no solo (REIS \& MARTINS, 1989; ROMÃO et al., 1994b).

Segundo LOVELESS (1983), as sementes de plantas de regiões áridas e semi-áridas têm mostrado ter embutido uma " medida da quantidade mínima de chuva" MQMC. Nelas existem substâncias que inibem a germinação, às quais são solúveis em água, e por essa razão lixiviadas pela chuva. A quantidade de chuva necessária para lixiviar esses inibidores está diretamente relacionada a quantidade de água necessária para completar seu curto ciclo de vida.

A posse desse fator MQMC, pelas sementes de plantas que vivem em hábitats extremamente irregulares com relação as chuvas, assegura que as espécies não sejam eliminadas como aconteceria se após a germinação simultânea de todas as sementes se seguisse uma seca a qual mataria todas as plântulas.

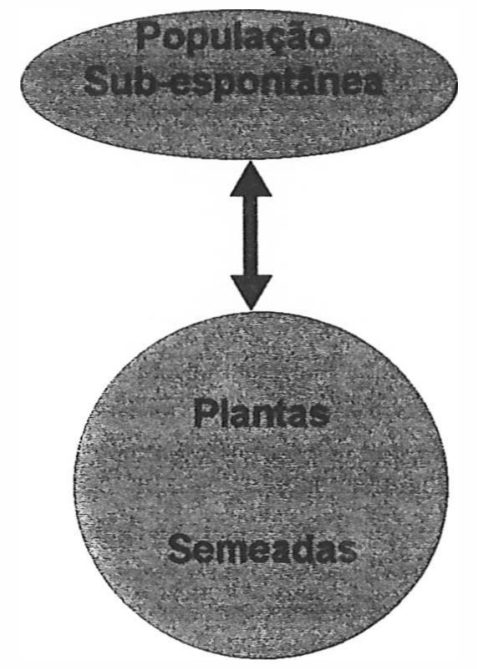

Figura 21. Fluxo de sementes e pólen dentro das roças. 


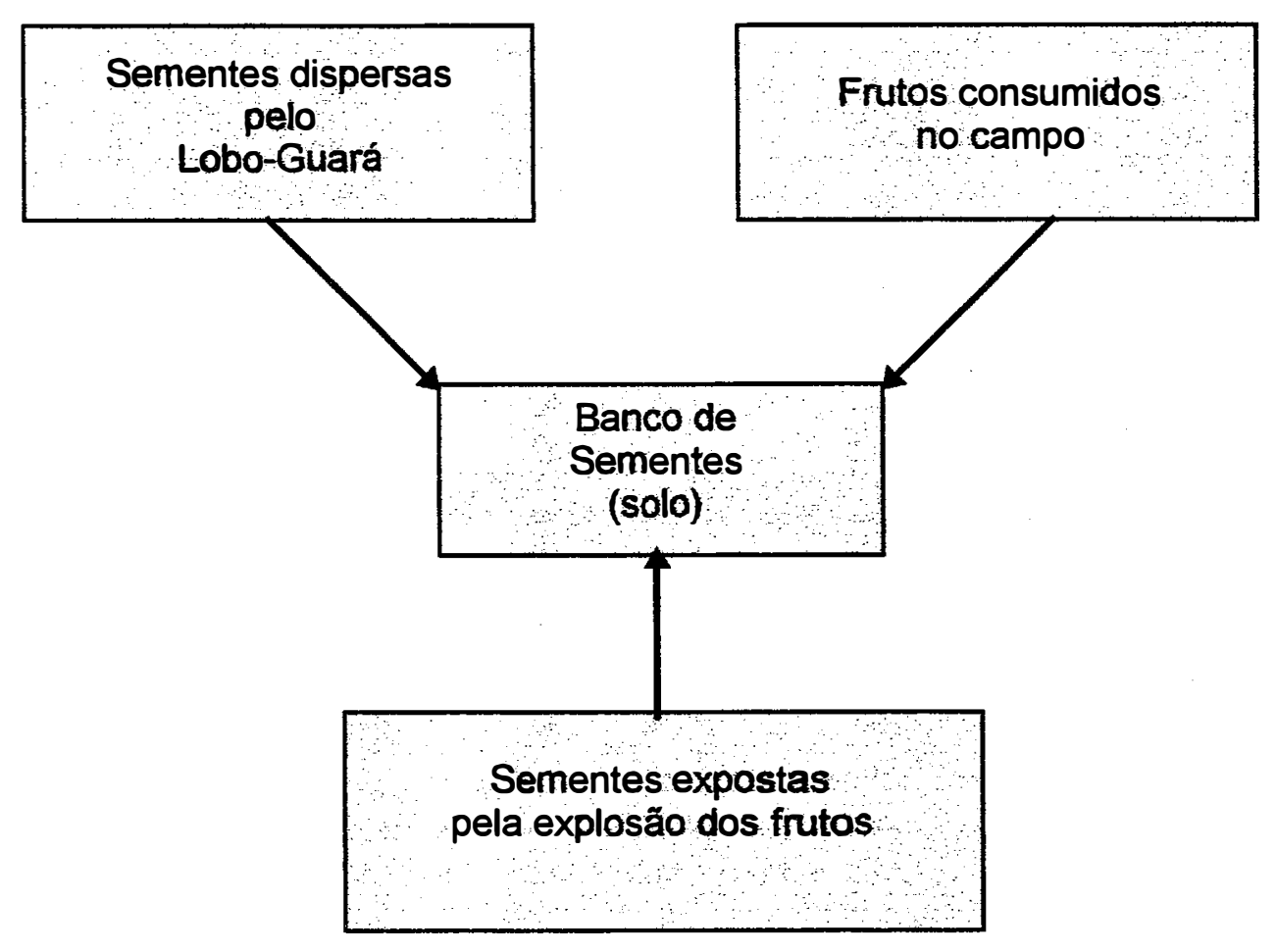

Figura 22. Fatores formadores do Banco de sementes de melancia no Nordeste do Brasil.

Este fator serve como estratégia de sobrevivência no caso das populações que estão na região 2 , e um pouco menos na região 3 , e tendo pouca importância na região 1 , devido a umidade ser mais alta nessas regiões. De fato, os resultados encontrados no trasbalho, indicam ocorrência de dormência apenas em populações da região 2. (Figuras 23 e 24)

Como fatores ecológicos que contribuem para a formação do banco tem-se o hábito dos agricultores de consumir o fruto na roça, deixando as sementes no solo, até o próximo periodo chuvoso, além do consumo do fruto e dispersão das sementes pelos lobos Guará, animais mamíferos canideos de hábitos noturnos, que são muito atraídos pelos frutos quando maduros (QUEIROZ, 1993). (Figura 25)

Estes fatores, juntamente com a persistência de populações em condições adversas e os diferentes sistemas de cultivo, possibilitam a formação de populações sub-espontâneas de melancia (ROMÃO et al., 1994b). 


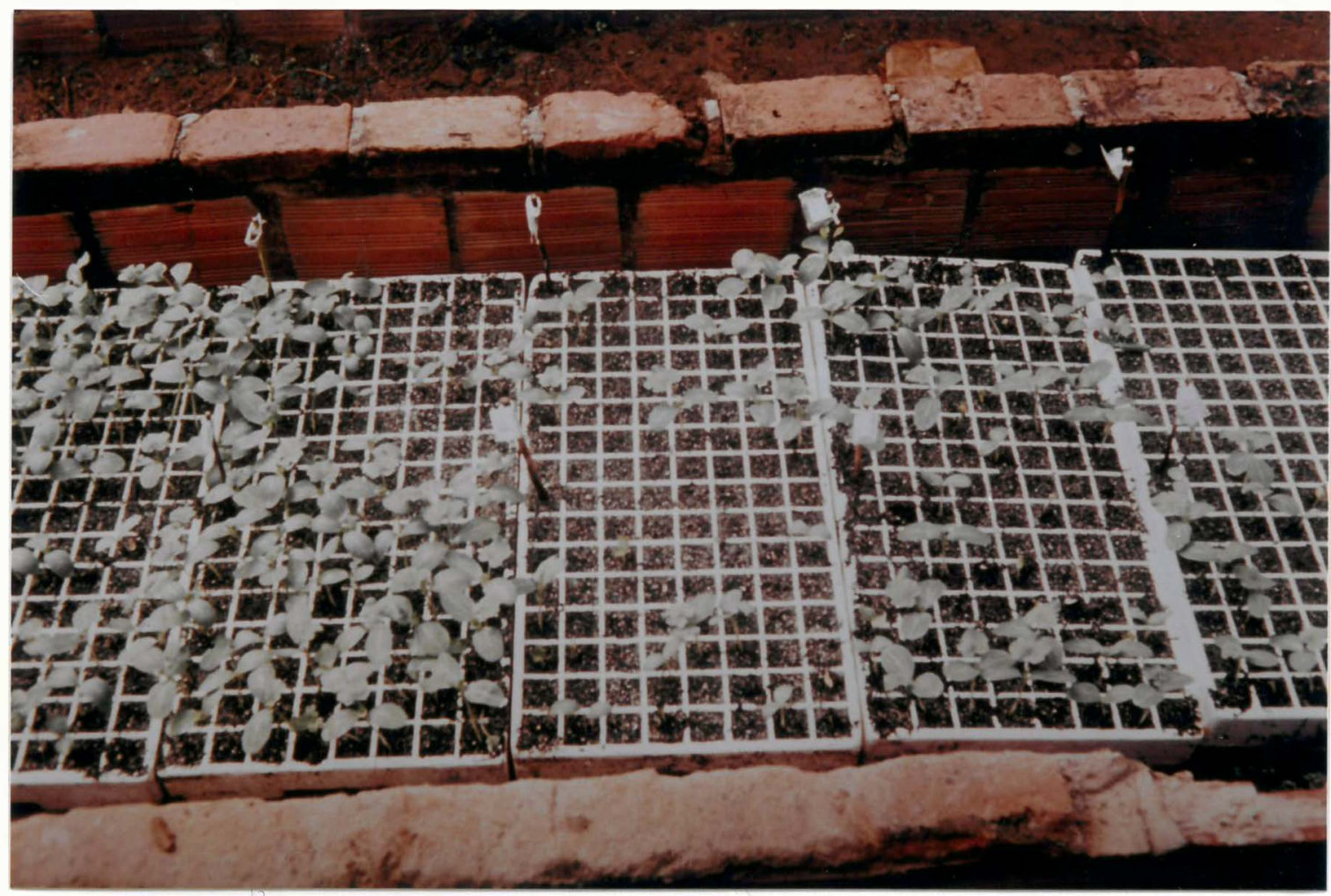

Figura 23. Vista geral das plântulas da região 2 - DS. Observa-se na primeira bandeja, na parte superior da figura à direita o acesso 1, e na terceira bandeja na parte inferior o acesso 6, que apresentou dormência.

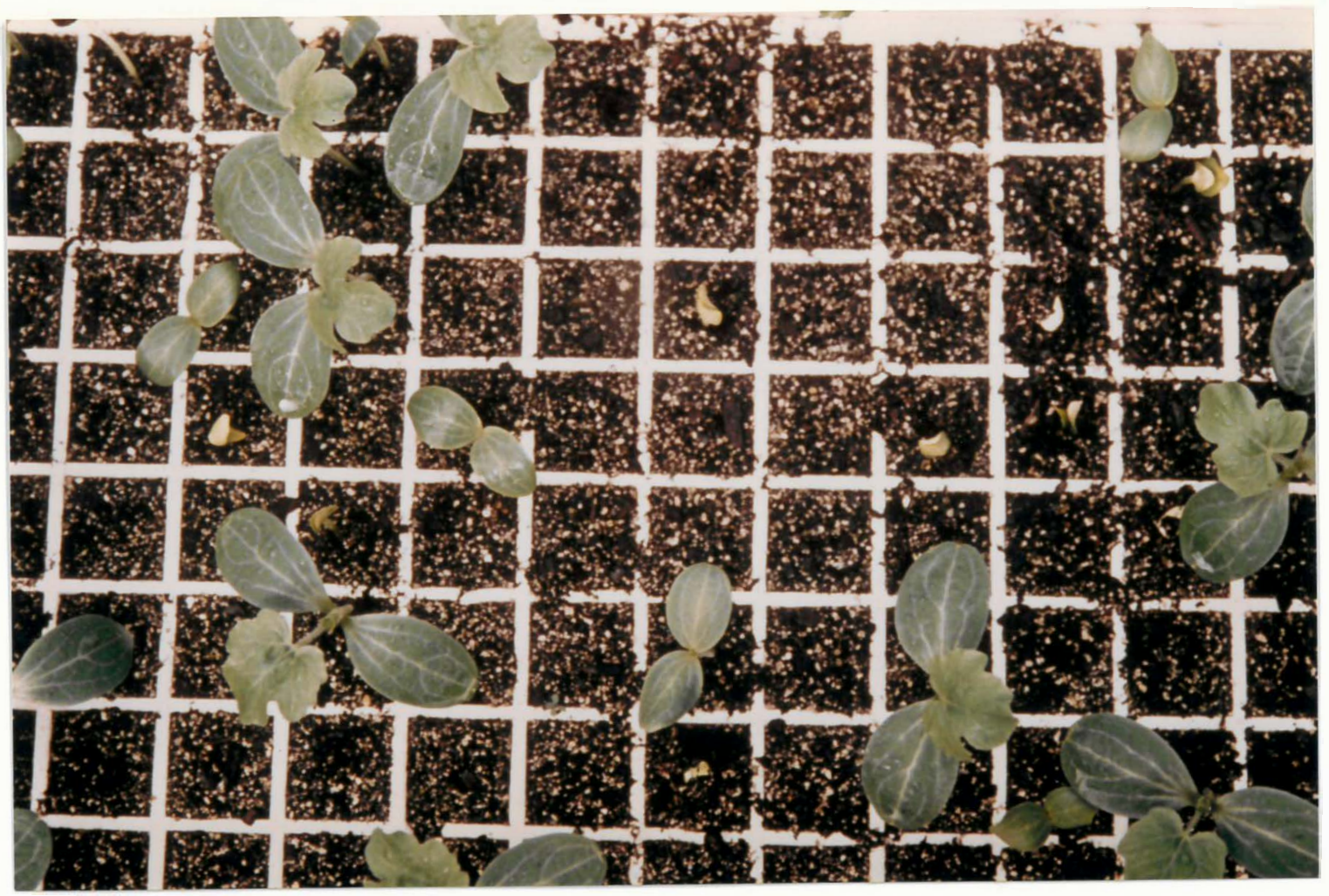

Figura 24. Detalhe da germinação do acesso 1 da região 2- DS, que apresentou dormência. 


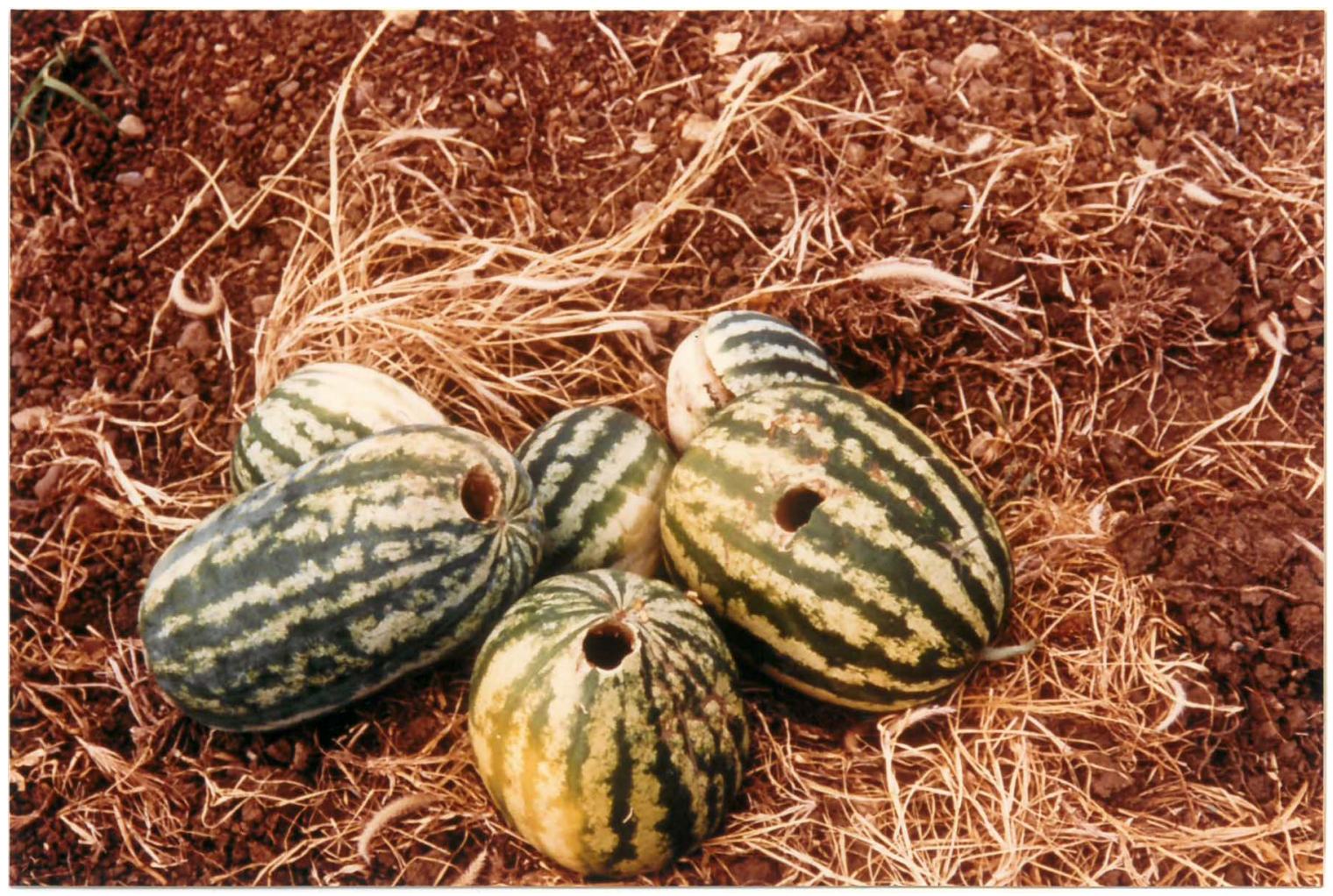

Figura 25. Detalhe de frutos de melancia apresentando furos feitos pelo lobo-Guará.

As populações sub-espontâneas devem ser resultado da permanência, nas variedades locais, de genes das populações selvagens (genes de dormência e gene que controla a explosão dos frutos), que possibilitam escapes de cultivos estabelecendo populações sub-espontâneas, mantidas pelo sistema de manejo dos pequenos agricultores.

Trabalhos recentes têm discutido a importância de se considerar a relação planta - homem/agricultor, sendo este o componente ativo do agroecossistema. SALICK (1995) ressalta que a botânica econômica e a etnobotânica interpretadas como interações planta/homem podem auxiliar no desenvolvimento da ecologia evolutiva.

As roças, consideradas como unidades evolutivas, neste estudo, sofrem ação de uma série de mecanismos evolutivos induzidos ou estimulados pelo agricultor e que influenciam a dinâmica evolutiva da melancia. 
O primeiro ponto a ser levantado é a facilidade ou hábito que os agricultores têm de permutar sementes própias. Isto pode ser causado por curiosidade a respeito de um determinado tipo de germoplasma, ou por necessidade no caso da perda do seu estoque de sementes, por perda da roça plantada pelo ataque de pragas e doenças ou mais comumente perda por seca.

A permuta de sementes resulta no processo de migração, que tem implicação direta no aumento de variabilidade à medida que permite a entrada de alelos novos no sistema.

O segundo ponto é o tipo de sistema de cultivo. Este pode se dar de três maneiras: 1 - roças onde as plantas surgiram por escape de cultivo e são mantidas como uma fonte alternativa de alimentação para a familia e para os animais; 2 - roças onde o cultivo tem como fim prioritário o consumo familiar com venda de excedentes; e, 3 - roças onde o cultivo é realizado visando diretamente a comercialização dos frutos (Massaroca DS).

Os sistemas de cultivo 1 e 2, atuam favorecendo a permanência nas populações de genes de dormência por não ocorrer seleção contra os mesmos. Por outro lado permitem o fluxo gênico entre população semeada e população germinada do banco, com posterior recombinação que aumenta a variabilidade dentro da roça.

No sistema 3 , há uma pressão maior sobre a variabilidade devido ao interesse do agricultor em selecionar um tipo específico, podendo causar uma diminuição da variabilidade dentro da roça.

Um terceiro ponto é o hábito dos agricultores e familiares de consumirem frutos no próprio roçado e lá mesmo deixarem as sementes. Isto tem como conseqüência a seleção de materiais com dormência, devido à morte das plântulas que germinam fora do período chuvoso onde a umidade não é suficiente para completar o ciclo. Esta seleção fixa o caráter produção de inibidores da germinação e possibilita a formação do banco de sementes.

O quarto e último ponto é a seleção dos frutos e estocagem de sementes para o plantio no ano seguinte. Essas atividades direcionam a variabilidade, e a sua intensidade vai depender do sistema de cultivo. Se o sistema de cultivo não é prioritariamente comercial (sistemas 1 e 2), esta seleção não é tão rigorosa, conseqüentemente não terá um peso muito grande na perda da variabilidade, mas no caso onde o cultivo é realizado objetivando diretamente a comercialização (sistema 3), e já se tem 
um mercado consumidor com determinadas exigências, essa seleção vai ser mais rigorosa, muito embora não signifique uniformidade total.

Os estudos relativos à biologia de populações em cucurbitáceas mostram alta taxa de autofecundação, fluxo de pólen irregular e restrito, e existência de populações sub-espontâneas (JENKIS, 1942; HANDEL, 1983; ROMÃO et al., 1994b).

Segundo HANDEL (1983), o fluxo de pólen localizado parece ser o maior componente de adaptação local em plantas e o responsável pela estrutura heterogênea observada em populações naturais.

Nas populações estudadas, o fluxo restrito de pólen não distribui a variabilidade por toda a população mas atua formando um mosaico de tipos, mesmo considerando que são populações de intercruzamento e estando, na maioria das vezes, em ambientes homogêneos, no espaço.

A alta taxa de autofecundação permite que combinações gênicas possam ser mantidas e o agricultor selecionando tipos específicos, favorece combinações gênicas já bastante estabelecidas.

As populações sub-espontâneas algumas vezes são compostas também pelas melancias usadas na alimentação animal chamadas vulgarmente de melancia-decavalo ou melancia-de-porco. Segundo ASSIS (1994), há evidencias de que a melancia-decavalo seja uma raça local de C.lanatus que carrega alelos de C. colocynthis como conseqüência da fácil hibridação que ocorre entre essas espécies, como observado por SINGH (1978); MAHESHWARI (1978); FULKS et al. (1979); e ZAMIR et al. (1984).

O fluxo gênico entre populações produz com a recombinação, arranjos genotípicos que são expostos a diferentes pressões de seleção natural, nesse caso, ligada as diferentes condições ecológicas dentro das regiões, e seleção artificial, empreendida pelos agricultores com objetivos específicos.

A manutenção dos híbridos na natureza é favorecida provavelmente pelas vantagens adaptativas que conferem os genes de resistência à doenças e pragas e a maior capacidade de resistência à estresses ambientais, conforme observado por ANTONOVICS (1971) e LEVIN \& KERSTER (1975). ARAÚJO et al. (1989) e DIAS et al. (1989), estudando materiais híbridos de melancia observaram genes de resistência a doenças.

Segundo STEBBINS (1970), a hibridação entre espécies traz novas possibilidades para as mutações, pois possibilita o estabelecimento de novas bases 
genéticas para aquelas que foram consistentemente rejeitadas pela seleção nas espécies ascendentes e $o$ efeito de combinações gênicas de natureza hibrida que estimulam a ocorrência de novas mutações.

A manutenção de populações relativamente pequenas segundo ALLARD (1971), é uma característica da biologia das populações de cucurbitáceas, que possibilita a ação do acaso. Esta ação, se a variabilidade inicial é pequena, pode agir eliminando ou fixando genes por efeito fundador e portanto, vai causar diminuição da variabilidade dentro das roças, e aumento da divergência entre roças.

As observações ecológicas realizadas, sugerem grande possibilidade de fluxo gênico através da semente, no caso da dispersão entre roças ou da germinação de sementes do banco. Segundo LOVELESS \& HAMRICK (1984), a dispersão por animais é grande e variável, podendo promover a ocorrência do efeito fundador e produzir diferenciação entre populações.

O fluxo de pólen, entre populações cultivadas, e populações subespontâneas deve ser considerado. Porém, como é restrito a pequenas distâncias conforme mostrou HANDEL (1983), para pepino (Cucumis sativus), e devido às abelhas polinizadoras, terem um padrão de movimentação restrito (LOVELESS\& HAMRICK,1984), aumenta a probabilidade de diferenciação (Figura 26).

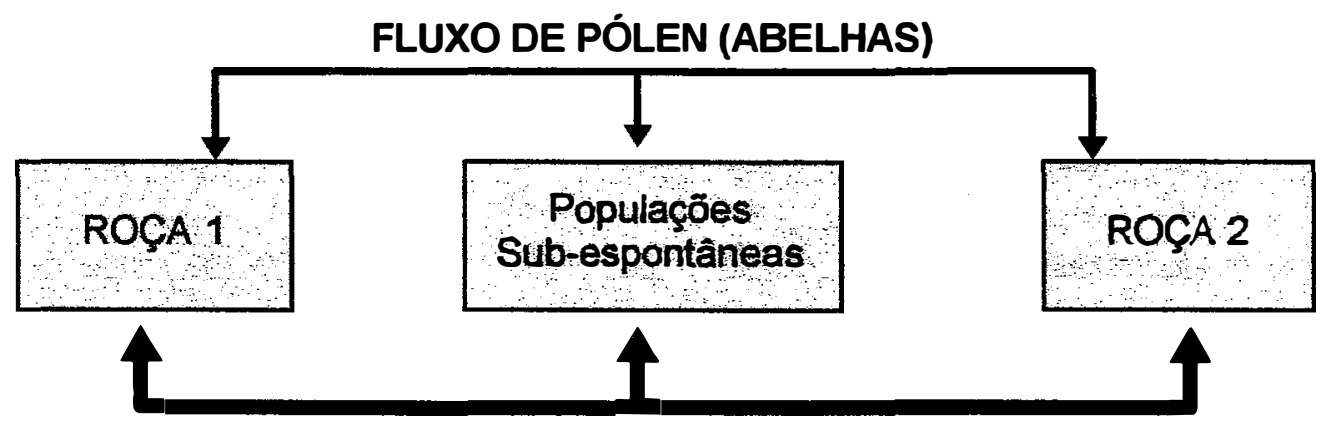

FLUXO DE SEMENTES (LOBO-GUARÁ)

Figura 26. Fluxo de sementes e pólen entre roças em cultivo de melancia.

Segundo Wright citado por MARTINS (1988), é o balanço de vários fatores evolutivos (mutação, migração, seleção, deriva) que determina o padrão de variação, e não um fator sozinho. 
Dentre os processos evolutivos considerados os que provavelmente estão atuando na dinâmica da melancia do Nordeste para diminuir a variabilidade dentro da roça e a aumentar a divergência entre roças são : efeito fundador, seleção natural e seleção artificial. Os processos que aumentam a variabilidade dentro da roça são: a hibridação, recombinação, mutação e migração.

\subsubsection{Considerações finais sobre a variabilidade em melancia.}

A grande variabilidade observada neste estudo para caracteres quantitativos e qualitativos, mostra que, para a maioria dos genes descritos na literatura para a espécie, segundo ROBINSON, et al. (1976) e MOHR (1986), (Tabela 8), foram encontrados os repectivos fenótipos entre os materiais estudados. Algumas exceções observadas como a ausência de intemódios curtos e macho esterilidade, são descritas como mutantes determinados por genes recessivos onde há ainda a possibilidade de os

mesmos estarem presentes nas populações em estado heterozigoto. Além disso, o número de populações estudadas representa apenas $10 \%$ das populações já coletadas e conservadas no BAG do CPATSA.

A história de ocupação do Nordeste, a grande variabilidade provavelmente introdüzida pelos africanos, associada aos diferentes sistemas de cultivo e às diferenças ecogeográficas seriam responsáveis pela amplificação, manutenção e aumento da variabilidade originalmente introduzida, como sugere a identificação de populações com o gene que confere a cor amarela ao fruto (QUEIROZ , 1993) não citado no trabalho clássico de ROBINSON, et al. (1976).

Por outro lado, Pastore citado por SOUZA (1979), mostra que estudos realizados sobre agricultura de subsistência no Brasil provam que os agricultores possuem razoável conhecimento sobre técnicas de produção (sementes melhoradas, uso de fertilizantes, épocas de plantio, entre outras), mas que não as aplicam por se acharem impotentes ou incapazes, face às restrições de caráter natural ou socio-econômico o que em certo aspecto concorre para fragilidade da conservação a longo prazo, da variabilidade existente nessas unidades produtivas, pois se restrições desaparecem, a tendência é abandonar as variedades tradicionais e adotar aquelas de maior valor no mercado.

Os sistemas de cultivo em pequenas propriedades no Nordeste brasileiro, apresentam algumas semelhanças com a agricultura autóctone dos caiçaras e comunidades negras do Vale do Ribeira (CURY, 1993), e com as das comunidades 
indigenas (KERR \& CLEMENT,1980). Entretanto, apresentam também, fortes diferenças com relação a sua colocação no contexto da produção agrícola.

A pequena agricultura do Nordeste tem o caráter de subsistência por estar em condições ecológica e econômica marginais. A formação cultural do agricultor não representa uma barreira à utilização de insumos como é o caso dos índios e caiçaras. Estes também, sofrem pequena pressão do mercado consumidor e as suas fortes tradições culturais tamponam as pressões externas (BRUSH, 1992). Ambas as situações provavelmente diminuem o risco de perda imediata dos seus recursos genéticos. Este aspecto concorre para fragilidade da conservação a longo prazo da variabilidade existente nas roças.

SILVA (1993) observou que existem grupos de agricultores que utilizam as variedades locais de melancia com objetivos comerciais como ocorre no distrito de Massaroca, Juazeiro-BA. Estes grupos caso se capitalizem, provavelmente trocarão as variedades locais por variedades comerciais melhor remuneradas. A diversidade genética neste caso, pode ser facilmente perdida, caso estes agricultores tenham algum tipo de subsídio como observado por QUEIROZ (1992).

Por outro lado, na década de 70 , foram realizados vários estudos em populações de coleções mundiais, com caracterização para quantificação da diversidade, relacionando-a a padrões regionais, ecológicos e climáticos. O exame da distribuição geográfica de características fenotípicas mostrou que a relação entre a variabilidade, a procedência das populações e os centros de origem e diversidade, em muitos casos, não foi consistente (JAIN et al., 1975; ASHRI, 1975;HOLCOMB et al. 1977; WU \& JAIN, 1977; TOLBERT et al., 1979 ).

Mais recentemente, na década de 80 , as idéias de Vavilov, de centro de origem, têm sido reexaminadas, e, em diversas culturas há evidências de origem difusa (HARLAN, 1971) segundo a qual as plantas mudam com o tempo na medida em que se difundem no espaço, e nas premissas de SIMMONDS (1979a), quando observa que raramente podemos falar em centro de origem no sentido de uma área relativamente pequena, numa parte bem definida de um país sugerindo a idéia de continuum geográfico de domesticação e evolução de plantas onde a agricultura é praticada.

O mesmo autor relata que, há pouca conexão entre fontes de ancestrais selvagens, área de domesticação e área de diversificação evolucionária. Algumas vezes duas ou mais destas coincidem, outras não. 
Tabela 8. Fenótipos de melancia descritos na literatura. (ROBINSON et al. 1976), e observados em populações do Nordeste.

\begin{tabular}{|c|c|c|}
\hline 1- Andromonoicismo $r^{\star \star}$ & monoicismo $d^{\star \star}$ & \\
\hline 2- polpa amarela $d^{\star \star}$ & polpa rosa $r^{\star \star}$ & \\
\hline \multicolumn{3}{|l|}{3 - sementes mosqueadas ${ }^{\star \star}$} \\
\hline \multicolumn{3}{|l|}{4 - internódios curtos $1 r$} \\
\hline \multicolumn{3}{|l|}{5 - internódios curtos $2 r$} \\
\hline \multicolumn{3}{|l|}{6 - casca explosiva ${ }^{\star \star}$} \\
\hline 7 - casca rugosa $r^{\star \star *}$ & casca lisa $d^{\star \star}$ & \\
\hline 8 - casca verde clara $r^{\star \star}$ & verde escuro $d^{\star \star \star}$ & \\
\hline 9 - listra verde escura $r d^{\star \star \star}$ & fruto verde escuro $d^{\star \star \star}$ & fruto verde claro \\
\hline \multicolumn{3}{|l|}{$\begin{array}{l}10 \text { - cor amarela nas folhas velhas e frutos } \\
\text { maduros. }{ }^{\star \star}\end{array}$} \\
\hline \multicolumn{3}{|l|}{11 - macho estéril $r$} \\
\hline 12 - sementes grandes $r{ }^{\star \star}$ & sementes médias $d^{\star \star \star}$ & \\
\hline 13 - sementes pequenas $e^{\star \star}$ & sementes grandes & \\
\hline 13 - folhas não lobuladas & folhas lobuladas ** & \\
\hline 14 - fruto oval id ${ }^{\star \star}$ & esférico ${ }^{\star \star}$ & \\
\hline 15 - frutos amargos C. colocynthis $d$ & frutos doces C. lanatus $r$ & \\
\hline 16 -sementes bronzeadas $d^{\text {** }}$ & sementes vermelhas $r{ }^{\star \star}$ & \\
\hline 17 - sementes verdes $d^{\star \star \star}$ & sementes vermelhas $r^{\star \star}$ & \\
\hline 18 - sementes pretas $d^{\star \star}$ & sementes brancas $r^{\star \star}$ & \\
\hline 19 - sementes com bordas pretas $r^{\star \star}$ & lisa $d^{* \star}$ & \\
\hline 20 - polpa branca d ${ }^{\star \star}$ & polpa vermelha $r^{\star \star}$ & \\
\hline 21 - polpa amarela $r^{\star \star}$ & polpa vermelha d & \\
\hline 22 - polpa amarela d & polpa rosa $r^{\star \star *}$ & \\
\hline 23 - frutos rendilhados ** & & \\
\hline 24 - frutos mosqueados ${ }^{\star \star}$ & & \\
\hline
\end{tabular}

r - recessivo; d - dominante; id - dominância parcial; e- epistático;

$\left.{ }^{(\star *}\right)$ caráter observado em populações do Nordeste.

Deve-se ressaltar ainda a importância da relação plantas cultivadas/homem, na criação da variabilidade, resultante das possibilidades que estas experimentam no próprio caminhar do homem: exposição a novos ambientes e a diferentes condições de estresse, a mistura de conjuntos gênicos antes isolados, a hibridação introgressiva (MARTINS, 1988).

Fundamentado na variabilidade encontrada (Tabela. 8), associada à padrões ecogeográficos e ao modelo de dinâmica evolutiva, e nas premissas de HARLAN 
(1971) e SIMMONDS (1979a), sugere-se ser o Nordeste brasileiro um centro de diversidade para a melancia (C. lanatus).

Com base nos estudos realizados sugere-se, que a estratégia de coleta de germoplasma de melancia no Nordeste deverá continuar, pois há grande chances de se encontrarem novos genes úteis em populações de outras regiões. Vale a pena salientar que existem complexos gênicos, bastante influenciados pelo ambiente, e portanto de dificil identificação, porém, de grande significado para o melhoramento de plantas, especialmente, características adaptativas. Desse modo, é importante a continuidade dos trabalhos de coleta.

Há ainda a possibilidade iminente da variabilidade, após caracterizada e avaliada ser utilizada nos programas de melhoramento da cultura, como sugerido por WHANG \& ZHANG (1988), para os materiais africanos.

Verifica-se ainda que 0 trabalho sobre recursos genéticos de cucurbitáceas de ESQUINAS-ALCAZAR \& GULICK (1983), cita o Nordeste como região prioritária para coleta de Cucunbita moschata, apenas. Entretanto, o presente estudo demonstra que a variabilidade genética do gênero Citrullus existente no Nordeste brasileiro é bastante expressiva sendo por conseguinte, uma região prioritária para coleta. É provável que quando se realizem estudos mais aprofundados com Cucumis ssp se chegue a conclusões semelhantes. 


\subsection{CONCLUSÕES}

1 - Com base nos dados históricos e no padrão de variabilidade das populações de melancia do Nordeste do Brasil, há indicações que os escravos africanos introduziram germoplasma com grande diversidade nesta região.

2 - O sistema de agricultura empregado pelos pequenos agricultores do Nordeste, permitiu a manutenção e ampliação da variabilidade das populações semeadas e sub-espontâneas de melancia.

3 - A variação observada para caracteres qualitativos se mostrou bastante distribuída entre as regiōes, entretanto, a presença de caracteres como padrão de casca (mosqueada) e cor de polpa (branca), associados a $C$. lanatus var. citroides, nas regiões 1 e 2, pode ser interpretada como evidência de maior introgressão, nestas regiões.

4 - A variabilidade intra-regional é resultado da variabilidade introduzida, do efeito fundador, da biologia das populações e da seleção do agricultor. Dentre estes, a ação dos agricultores, parece ser fundamental na medida que altera processos da biologia das populações que ocorrem ao nível da roça.

5 - A diferenciada distribuição da variabilidade entre as regiões está relacionada à padrões de natureza histórica e biológica.

6 - Os diferentes ambientes, dentro da região 2 (Depressão Sertaneja) , a sua localização em área estratégica, a existência de agentes dispersores e o ambiente ecologicamente muito semelhante ao da região de origem da melancia aliado ao manejo dos agricultores parece ter contribuido para que esta região apresente maior variabilidade.

7 - A variabilidade tem uma relação estreita com as regiões. Desse modo, a coleta de germoplasma deve ter como critério básico a região geográfica. Hà possibilidade de se encontrarem outros caracteres de interresse realizando-se coletas em outras áreas de cultivo tradicional com ambientes ecológicos distintos dos estudados,.

8 - O modelo proposto de dinâmica evolutiva tem componentes históricos (o tráfico de escravos e a colonização do Nordeste); componentes genéticos (dormência e explosão dos frutos), e componentes ecológicos (dispersão das sementes pelo 
lobo Guará e sementes deixadas no campo após consumo de frutos pelo agricultor no próprio campo).

9 - Há formação de um banco de sementes no solo com sementes da melancia cultivada (C.lanatus) e da melancia-de-cavalo (C.lanatus var. citroides). Este banco possibilita a existência de populações sub-espontâneas e o fluxo gênico entre esses taxa.

10 - O intercruzamento entre populações semeadas e populações subespontâneas, aumenta a variabilidade nos cultivos de melancia.

11 - O Nordeste brasileiro é um centro de diversidade para melancia (Citrullus lanatus) e, consequentemente, uma área importante para coleta de germoplasma.

12 - O descarte de variáveis através do critério de eliminação daquelas com coeficientes canônicos padronizados abaixo de $\pm 0,70$, em pelo menos um dos coeficientes canônicos, reduz $47 \%$ das variáveis utilizadas. Desse modo as variáveis, comprimento de cotilédone, peso de fruto, diâmetro de fruto, comprimento de fruto, - espessura de polpa, brix, peso de 50 sementes, tamanho de semente e diâmetro do ramo principal, são as mais apropriadas para caracterizar a variabilidade em populações de melancia.

13 - O emprego de uma lista simplificada de 21 descritores, sugerida neste trabalho, facilitaria a caracterização a qual seria útil tanto para os trabalhos de recursos genéticos como para o melhoramento vegetal, pois possibilitaria a descrição da variabilidade e estudo da divergência em populações de melancia.

14 - A variabilidade qualitativa e quantitativa encontrada sugere que, algumas populações podem vir a integrar programas de melhoramento que objetivem 0 desenvolvimento de variedades nacionais adaptadas às condições do Nordeste, bem como podem servir ao melhoramento in situ, realizado em parceria com agricultores, visando a obtenção de materiais superiores adaptados às áreas dependentes de chuva. 


\subsection{REFERÊNCIAS BIBLIOGRÁFIAS}

ABUSULEHA \& DUTTA, O. P. Studies on variability, heritability and scope of improvement in cucumber. Haryana Journal of Horticultural Sciences, India, 19 (3/4) : 349-52, 1990.

ALLARD, R. W. Princípios do melhoramento genético das plantas. São Paulo. Blucher, 1971. 381p.

ANDRADE, M. C. de. O processo de ocupação do espaço regional do Nordeste. Recife, SUDENE, 1975. 67p. (Série Estudos Regionais,1).

ANDRADE, M. C. de. A terra e o homem no nordeste. São Paulo, Ciências Humanas, 1980. 278p.

ANTONOVICS, J. Evolution in closely adjacent plant populations V. Evolution of selffertility. Heredity, Waschington, 23 : 219-238, 1968.

ARAUJO, J. P. de \& SOUZA, R. C. Avaliação de germoplasma de melancia em Petrolina, PE, visando a resistência a oídio (Sphaeroteca fuliginea). In: CONGRESSO BRASILEIRO DE OLERICULTURA, 27, Curitiba, 1987. Resumos. Curitiba, SOB, 1987.

ARAUJO, J. P. de; SOUZA, R. C. S. Avaliação de germoplasma de melancia com provavel resistência mêcanica ao vírus WMV-1 em Petrolina (PE). Horticultura Brasileira, Brasília, 6 (1) : 45, maio, 1988.

ARAUJO, J. P. de; DIAS, R. C. S.;QUEIROZ, M.A. de.; PESSOA, H.B.S.V. Avaliação de linhas e germoplasma de melancia visando resistência ao virus WMV-1. Horticultura Brasileira, Brasília,.7 (1) : 41, maio, 1989.

ARAUJO, J. P. de; SOUZA, R. C.;QUEIROZ, M. A. de; CANDEIA, J. A. Avaliação de germoplasma de melancia, em Petrolina-PE, visando à resistência à oídio (Sphaeroteca fuliginea). Horticultura Brasileira, Brasília, 5 (1) : 48, maio, 1987.

ASHRI, A. Evaluation of the germ plasm collection of safflower, Carthamus tinctorius L.V. Distribuition and regional divergence for morphological characters. Euphytica, Dordrecht, 24:651-9, 1975.

ASSIS, J. G. A. Estudos genéticos no gênero Citrullus. Jaboticabal, $1994.99 p$. (Mestrado - Universidade Estadual Paulista). 
BERG, M. E. van den. Plantas de origem africana de valor sócio-econômico atual na região amazônica e no Meio - Norte do Brasil. _Boletim do Museu Paraense Emílio Goeldi. Belém, 7 (2) : 499-504, 1991.

BREESE, E. L. Regeneration and multiplication of germplasm resources in seed genebanks : the scientific background. Rome, IBPGR, 1989. 69p.

BRUSH, S. B. Reconsidering the green revolution: diversity and stability in creadle areas of crop domestication. Human Ecology, New York, 20 (2), 145-67, 1992.

CARVAlHo, N. M. de; CAStelane, P. D. ; VIEIRA, R. D. Produção de sementes de melancia. Jaboticabal, FUNEP/FCAV-UNESP, 1988. 30p.

CLARK, N. \& JUMA, C. Biotechnology for sustanible development. Policy options for developing countries. Naiarobi, African Centre for Technology Studies, 1991. $117 p$.

- CLEVELAND, D. A.; SOLERI, D.; SMITH, E. S. Do folk crop varieties have a role in sustainable agriculture?. BioScience, Washington, 44 (11) : 740-51, 1994.

COSTA, N. D. Informações técnicas sobre a cultura da melancia. Petrolina, EMBRAPACPATSA, 1991. 10p.

COSTA, M.S.V. Relatorio de projeto em andamento. Petrolina-PE, EMBRAPA/CPATSA, 1992. 44p.

CURY, R. Dinâmica evolutiva e caracterização de germoplasma de mandioca (Manihot esculenta Crantz), na agricultura autóctone do Sul do Estado de São Paulo. Piracicaba,1993. 103 p.(Mestrado - Escola Superor de Agricultura "Luis de Queiroz"/ USP).

DEVI, D. S.; BALAKRISHNAN, R. ; PAULAS, D. ; SUBBIAH, R.; NATARAJAN, S. Evaluation studies in pumpikin (Cucurbita moschata Poir.). South Indian Horticulture, India, 37 (5): 274-6. 1989. Apud. Plant Breeding Abstract 1990. (ref 684).

DIAS, R. C. S.; ARAUJO, J.P. de, QUEIROZ, M.A. de. Resistência de populações de Citrullus ao oídio (Sphaeroteca fuliginea). Horticultura Brasileira, Brasília, 7 (1) : 52, maio, 1989.

DIAS, R. C. S. \& QUEIROZ, M. A. de. Melhoramento genético de melancia. Obtenção de progênies tolerantes ao oídio (Sphaeroteca fuliginea) e com boas caracteristicas de fruto. Horticultura Brasileira, Brasilia, 10 (1) : 53, maio, 1992. 
ENGELS, J. M. M. Variation in Sechium edule in Central America. Journal American Society Horticultural Science, New York, 108 (5): 706-10, 1983.

EPLEING, C. \& DOBZAHNSKY, T. H. Genetic of natural populations VII. Microgeographical races in Linanthus parryae. Genetics, $27:$ 317-33, 1942.

ESQUINAS -ALCAZAR, J. T. \& GULICK, P. J. Genetics Resources of Cucurbitaceas. Rome, IBPGR, 1983. 101p. (IBPGR - 82/84).

FARBER, V. V. Genetic sources for various trends in breeding cucumber. Sbornik Nauchnykn trudov po Prikladnoi Botanike, Gentike i Selektsii, Praga , 133: 868, 1990. Apud Plant Breeding Abstract 1989. (ref 10574).

FRANKEL, O. H. \& BENNETT, E. Genetic resources in plants - their exploration and conservation. Oxford, Blackwell, 1970. 554p. (IBPGR Handboock, 11).

FRANKEL, O. H. \& SOULE, M.(eds.). Conservation and Evolution. Cambridge University Press. 1981. 327p.

FREYRE, G. de M. Casa Grande e senzala : formação da familia brasileira sob regime de economia patriarcal. 13 ed. Rio de Janeiro, José Olympio, 1966. 2v.

FULKS, B. K.; SCHEERENS, J.C.; BEMIS, W. P. Natural hybridization of two Citrullus species. Journal of Heredity, New York, (70) : 214-5. 1979.

GIACOMETTI, D. C. Descritores para caracterização e avaliação de germoplasma. In: ENCONTRO SOBRE RECURSOS GENÉTICOS DE PLANTAS, 1, Jaboticabal, 1988. Anais, Jaboticabal, 1988. p.129-34.

GOMES, F. P. Curso de estatistica experimental. 9 ed. Piracicaba - SP, Nobel, 1981, 430p.

GRAYBILL, F. A. An introduction to linear statistical models. New York, McgrayHill, 1961, 459p.

HANDEL, S. N. Contrasting gene flow patterns and genetic subdivision in adjacent populations of Cucumis sativus (Cucurbitaceae). Evolution, Lancaster, 37 (4) : 760-71, 1983.

HARLAN, J. R. Agricultural origins; centers and noncenters. Science, Washington, 174 : 468-74,1971.

HARLAN, J.R. Crops and man. American Society Agronomy. Madinson, 1975. 284p. 
HARPER, J. L. \& OGDEN, J. The reproductive strategy of higher plants. The concepts of strategy special reference to Senecio vulgaris L. Journal of Ecology, Oxford, 58 : 681-98. 1970

HEARGREAVES, G. H. Monthly precipitation probabilities for Northest Brazil. Logan, Utah State University, Department of Agricultural and Irrigation Engineering, 1973. 423p.

HOLDEN, J. H. W. The second ten years. In: Crop genetic resources : conservation and evaluation. George Allen, 1984. p 175-185.

IBPGR, Elsevier dictionary of plant genetic resources. Rome : International Board for Plant Genetic Resources, 1991. 187p.

JAIN, S. K.; QUALSET, C.O.; BHATT, G. M.; e WU, K. K. Geographical patterns of phenotypic diversity in a world collection of durum wheat. Crop Science, Madison, 15:700 -04, 1975.

- JEFFREY, C. Further notes on Cucurbitaceae : III. Some Southem African taxa. Kew Bulletin, Londres 30 : 475-93, 1975.

JENKIS, J. M. JUNIOR Natural self-pollination in Cucumbers. Proceedings of the American Society for Horticultural Science, New York, 40 : 411-12, 1942.

KEAY, W. J. \& HEPPER, F. N. Cucurbitaceae. in The flora of west tropical Africa. 2.ed. Londres, Royal Botanic Gardens, 1985. 570-4p.

KERR, W. E. \& CLEMENT, C. R. Práticas agricólas de consequência genéticas que possibilitam aos indios da Amazônia uma melghor adaptação às condições ecológicas da região. Acta Amazonica, Manaus, 10 (2): 251-61, 1980.

KRISHNAIAH, P. R. \& KANAL, L. N. Classification pattern recognition and redution of dimensionality. Amesterdan; North-Holland, 1982. 903p. (Handbook of statistics v.2)

LALTA PRASAD; GAUTAM, N. C. ; SINGH, S. P. Studies on genetic variability and character association in watermelon ( Citrullus lanatus (Thumb) Mansf.). Vegetable Science, India, 15 (1) : 86-94, 1988. Apud Plant Breeding Abstract, 60 (5) : 56, 1990.

LEITE, J. L.; ARAUJO, M. P.; OLIVEIRA, C.A.; REIS, J. G. Area Ch - Projeto Favela Juazeiro-BA. Levantamento detalhado de solos. Recife, PE : SUDENE - DRN, 1971. 123p. 4 mapas (SUDENE. Serie Pedologia, 7).

LEVIN, D.A. \& KERSTER, H. W. The effect of gene dispersal on the dynamics and statics of gene substituition in plants. Heredity, Waschington, 35 : 317-36. 1975. 
LOVELESS, M. D. \& HAMRICK J. L. Ecological determinants of genetic structure in plant populations. Annual Revew Ecological Systematics. Palo Alto, 15 : 65-95, 1984.

LOVELESS, A. R. Principles of plant biology for the tropics. New York, Longman, 1983. p.387-532.

LUETZELBURG, P. von. Estudo botanico do nordeste. 2ed. Mossoro : ESAM/CNPQ, [( 1974)]. v.1. il. ( ESAM. Coleção Mossoroense, 166).

MAHESHWARI, J. K. Nomenclatural revision of some cultivaded watermelon. Indian Journal For, Dehra Dun, p.179-81. 1978.

MALLICK, M. F. R. \& MASUI, M. Origin, distribuition and taxonomy of melons. Scientific Horticulture. Inglaterra, 28 : 251-261, 1986.

MARTINS, P. S. Preservação e genética evolutiva. In: ARAÚJO, S. M. C. de; OSUNA, J. A. ENCONTRO SOBRE RECURSOS GENÉTICOS DE PLANTAS, 1, Jaboticabal,1988. Anais, Jaboticabal, 1988, p.62-6.

MEEUSE, A. D. The Cucurbitaceae of Southern Africa. Bothalia, Pretoria, (8): 1-111, 1962.

MOHR, H. C. Watermelon breeding. In : BASSET, M. I. Breeding in Vegetables Crops. Westport, Avi, 1986. p. 33-66.

NASS, L. L.; PELICANO, I. J.; VAQLOIS, A.C.C. Utilization of genetic resources for maize and soybean breeding in Brazil. Revista Brasileira de Genética, Ribeirão Preto, 16 (4) : 983-88, 1993.

NAVOT, N. \& ZAMIR, D. Isozyme and seed protein phylogeny of the genus Citrullus (Cucurbitacea). Plant Sytematics and Evolution, New York, 156(1/2): 61-7, 1987.

PAZ, J. E. da, coord. Dados pluviométricos mensais do Nordeste : Estado Maranhão. Recife : SUDENE, 1990. 103p. (SUDENE. Série Pluviometria, 1).

PEETERS, J. P. \& WILLIAMS, J. T. Towards better use of genebanks with special reference to information. Plant Genetic Resources Newsletter, Rome, $60: 22-32$, 1984.

PERRY, M. C.; MCINTOSH, M. S. ; STONER, A. K. Geographical patterns os variation in USDA soybean germplasm collection. I. Crop Science, Madison, 31(5) : 1350-5, 1991.

PINTO, C. A. B. P. Melhoramento de hortaliças. Piracicaba, ESALQ, 1977. 319 p. 
PORTO, J. C. Formação histórica do Nordeste. In: BANCO DO NORDESTE DO BRASIL (Recife, PE). Recursos e necessidades do Nordeste. Recife, 1964. p. 23-9.

QUEIROZ, M. A. de. Potencial do germoplasma de Cucurbitaceas no Nordeste brasileiro. Horticultura Brasileira, Brasília, 11 (1):7-9. 1993.

QUEIROZ, M. A. de. Recursos genéticos nos trópicos : o caso das plantas cultivadas por sementes. In : SEMINARIO DE TROPICOLOGIA, Recife, 1985. Anais. Recife, FUNDAJ ed. Massangana, 1992. tomo 19, p.169-96. (Cursos e Conferências, 45).

QUEIROZ, M. A. de; DIAS, R. C. S.; RAMOS, S. R. R.; COSTA, M. S. V. Frequencia de fontes de resistência à Didymella bryoniae. In: ENCONTRO DE GENETICA DO NORDESTE, 10, 1994. João Pessoa, Resumos. João Pessoa, UFPB/SBG/CNPAEMBRAPACNPQ, 1994, p. 106.

QUEIROZ, M. A. de; RAMOS, S.R.R.; ROMÃO, R.L.; ASSIS, J.G. A. Coleta de germoplasma de Cucurbita moschata e Cucurbita maxima em duas regiōes do Nordeste brasileiro. In : SIMPOSIO LATINO AMERICANO SOBRE RECURSOS GENÉTICOS DE ESPÉCIES HORTÍCOLAS, 2, Mar del Plata, 1991. Resumos. Mar del Plata, Associacion Argentina de Horticultura, 1991. p18.

RAMOS, S.R. R. \& QUEIROZ, M. A. de. Coleta de germoplasma de Citrullus lanatus, Cucumis sp. e Lagenaria siceraria em duas regiöes do Nordeste brasileiro. In : ENCONTRO DE GENÉTICA DO NORDESTE, 8, Resumos, São Luis, Sociedade Brasileira de Genética, 1992. p.65.

REIS, M. S. \& MARTINS, P.S. Efeito do dimorfismo da fruto de espécies de Stylosanthes sobre a germinação de sementes. Revista Ceres, Viçosa, 36 (206) : 348-56, 1989.

REYMENT, Multvariated morphometrics In: KRISHNAIAH, P.R.; KANAL, N. L. Classification pattern recognition and reduction of dimensionality. Amesterdam, North-Holland Publishing, 1982.

RIBEIRO, E. Juàzeiro na esteira do tempo. Salvador, Mensageiro da Fé, 1968. Cap. 1, p. $13-5$.

ROBINSON, R. W.; MUNGER, H. M.; WHITAKER, T.W.; BOHN, G. W. Genes of Cucurbitaceae. Journal of Horticultural Science, London, 11(6) : 554-68, 1976.

RODRIGUES, N. Os africanos no Brasil. 6 ed. São Paulo, Nacional, 1982. 283p. (Brasiliana, 6). 
ROMÃO, L. R.; ASSIS, J. G. A.; QUEIROZ, M. A. de. Caracterização botânicoagronômica de 14 acessos de melancia do BAG Cucurbitaceas do CPATSAIEMBRAPA. In : CONGRESSO NACIONAL DE GENÉTICA, 40., Caxambu, 1994. Resumos. Caxambu, SBG, 1994a. p.350.

ROMÃO, L. R.; MARTINS, P.S.; QUEIROZ, M. A. de.; RAMOS, S. R. R. Observações ecologicas sobre o cultivo da melancia no Nordeste do Brasil. In: ENCONTRO DE GENÉTICA DO NORDESTE, 10, 1994, João Pessoa. Resumos. João Pessoa: UFPB/SBG/CNPA-EMBRAPA/CNPQ, 1994b, p.116.

ROMÃO, R. L.; QUEIROZ, M. A. de.; VENCOVSKY, R.; ASSIS, J.G. de A. Metodologia para multiplicação de acessos de melancia do BAG Cucurbitaceas do CPATSAVEMBRAPA. In : CONGRESSO NACIONAL DE GENÉTICA, 40, Caxambu, 1994, Resumos. Ribeirão Preto; SBG, 1994c. p. 327.

SALDANHA, P. H. Mistura de raças mistura de genes. Ciência Hoje, Rio de Janeiro, 9(50) : 48-53, 1989.

- SALICK, J. Toward an integration of evolutionary ecology and economic botany: personal perspectives on plant/people interactions. Annual_Missouri Botanical Garden. Saint Louis, 82: 25-33, 1995.

SILVA, P. C. G. da. Um sistema de financiamento das atividades rurais adaptado à pequena produção da região de Massaroca, Juazeiro-BA. Campina grande, 1994. 260p. (Mestrado - Universidade Federal da Paraiba - Centro de Humanidades ).

SILVA, F. B. R. e ; RICHÉ, G. R. ; TONNEAU, J.P.; SOUZA NETO, N. C. de; BRITO, L. T. de L.; CORREIA, R.C.; CAVALCANTI, A.C.; SILVA, F.H.B.B. da ;SILVA, A. B.da.; ARAUJO FILHO, J. C. de.; LEITE, A. P. Zoneamento agroecologico do Nordeste : diagnóstico do quadro natural e agrossocioeconomico. Petrolina, PE : EMBRAPA-CPATSA Recife: EMBRAPA-CNPMS-Coordenadoria Regional Nordeste, 1993. 2v. 1 mapa. (EMBRAPA-CPATSA. Documentos, 80).

SIMMONDS, N.W. Evolution of crop plants. London : Longman,. 1979a, 339 p.

SIMMONDS, N.W. Principles of crop improvement. London : Longman, 1979b, p.408.

SINGH, A. K. Cytogenetics of semi-arid plants. III. A natural interespecific hybrid of Cucurbitaceae ( Citrullus colocynthis Schrad x C. vulgaris Schrad). Cytologia, Tokyo, 43 (3/4) : 569-574. 1978.

SIROHI, P. S. Genetic diversity in cucurbits... bittergourd. Indian Horticulture, Bangala, 35 (4):36, 1991. Apud Plant Breeding Abstract 1990 (ref. 1665). 
SOUZA, R. C.; ARAUJO, J.P. de; QUEIROZ, M.A. de. Avaliação da resistência de acessos de melancia ao oídio (Sphaeroteca fuliginea). Horticultura Brasileira, Brasília, 6 (1) : 82, 1988.

SOUZA, J. G. de. O Nordeste brasileiro : uma experiência de desenvolvimento regional. Fortaleza : BNB/ Fundação Getulio Vargas, 1979. 409.

STEBBINS, G. L. Processos de evolucão orgânica. São Paulo, Poligonol Universidade de São Paulo, 1970. 225p.

THIERET, J. M. The correct name of the watermelon. Taxon, Utrecht, $12: 36,1963$.

TOLBERT, D. M.; QUALSET, C.O.; JAIN,S.K.; CRADDOCK, J.C. A diversity analysis of a world collection of Barley. Crop Science, Madison, (19) : 789-94, 1979.

VALLS, J. F.M. Caracterização morfologica, reprodutiva e taxonômica de germoplasma vegetal. In: ENCONTRO SOBRE RECURSOS GENÉTICOS DE PLANTAS, $1 .$, Jaboticabal, 1988. Anais. Jaboticabal, 1988. p.106-28.

VERGER, P. Fluxo e Refluxo; Do trafico de escravos entre o Golfo do Benin e a Bahia de Todos os Santos: dos séculos XVII a XIX. 3. ed. São Paulo, Currupio, 1987. $718 p$.

VIEIRA, I. C. G. \& MARTINS, P. S. Caracterização morfógica da fruto e semente de Stylosanthes angustifolia VOG. (LEGUMISAE-PAPILIONOIDEAE) e sua relação com a germinação. Boletim do Museu Paraense Emilio Goeldi, Belém, 7 (2) : 287-300, 1991

VILELA-MORALES, E. A. \& MENDES, R. A. Reunião sobre recursos fitogenéticos de interesse no cone sul. Relatorio do Centro Nacional de Recursos Genéticos. Brasília, EMBRAPA-CENARGEN, 1983. 171p.

WALTERS, T.W. Historical overview on domesticated plants in China with special emphasis on the Cucurbiceae. Economic Botany, New York, 43 (3):297-313, 1988.

WHANG, M. \& ZHANG, X. P. Evaluation and utilization of the valuable African watermelon germplasm. Report, Cucurbit Genetic Cooperative. Madison, 11 : 69, 1988. Apud Plant Breeding Abstract 1989. (ref. $n^{0} 059-05262$ ).

WHITAKER, T. W. \& DAVIS, G. N. Cucurbits : botany, cultivation, and utilization. New York, Interscience, 1962. 250p.

WILLIAMS, J. T. A decade of crop genetic resources research. In: Crop genetic resources : conservation and evolution. London, George Allen, 1984, 296p. 
WU, K. K. \& JAIN, S. K. A note on germplasm diversity in the world collection of safflower. Economic Botany, New York, (31):72-5, 1977

ZAMIR, D.; NAVOT, N.; RUDICH, J. Enzyme polymorphism in Citrullus lanatus and Citrullus colocynthis in Israel and Sinai. Plant Sytematic and Evolution. New York, 146 : 163-70, 1984. 